\title{
WRR
}

WETENSCHAPPELIJKE RAAD VOOR HET REGERINGSBELEID

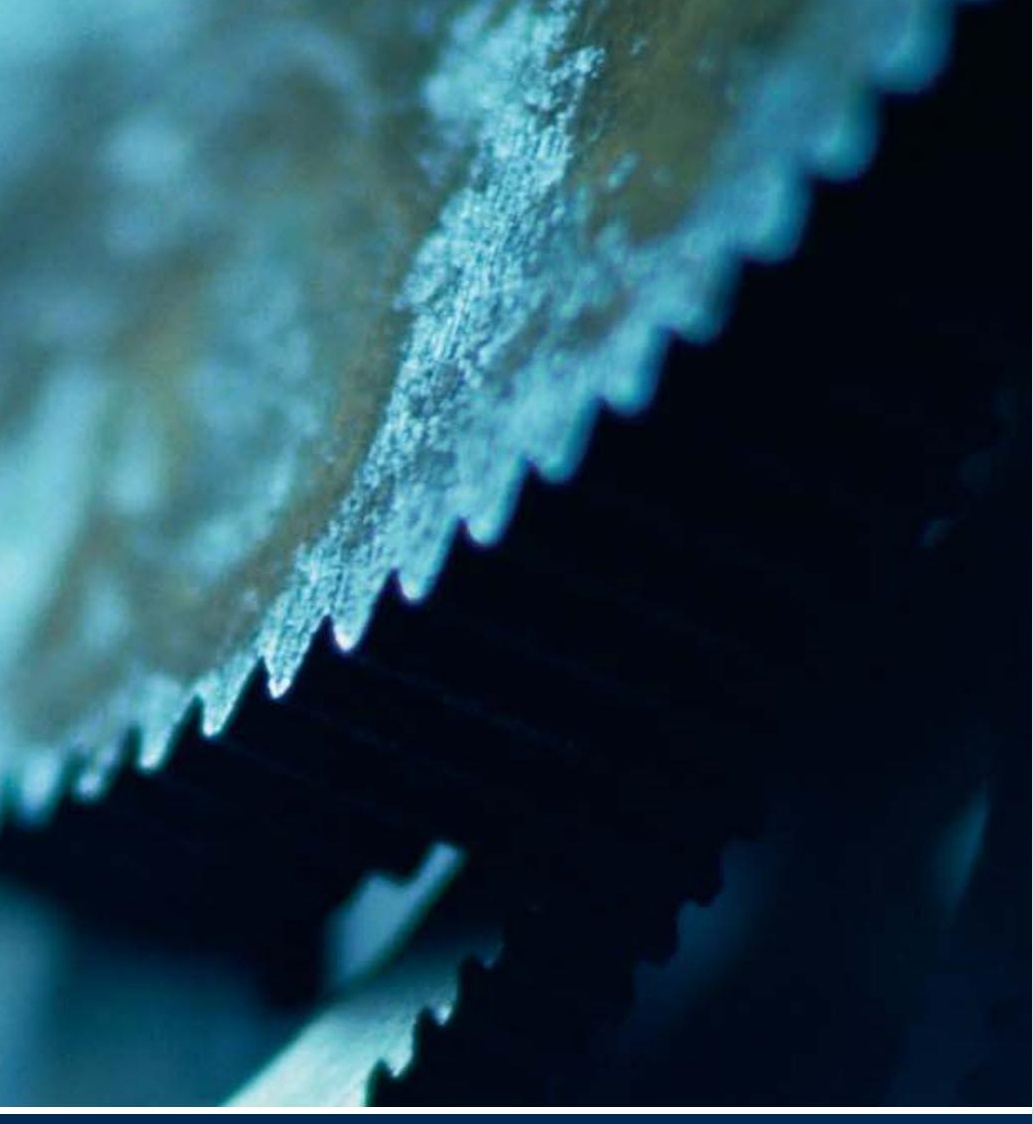

\section{Innovatie vernieuwd \\ OPENING IN VIERVOUD}


Innovatie vernieuwd 
De Wetenschappelijke Raad voor het Regeringsbeleid werd in voorlopige vorm ingesteld in 1972. Bij wet van 30 juni 1976 (Stb. 413) is de positie van de raad definitief geregeld. De huidige zittingsperiode loopt tot 31 december 2007.

Ingevolge de wet heeft de raad tot taak ten behoeve van het regeringsbeleid wetenschappelijke informatie te verschaffen over ontwikkelingen die op langere termijn de samenleving kunnen beïnvloeden. De raad wordt geacht daarbij tijdig te wijzen op tegenstrijdigheden en te verwachten knelpunten en zich te richten op het formuleren van probleemstellingen ten aanzien van de grote beleidsvraagstukken, alsmede op het aangeven van beleidsalternatieven.

Volgens de wet stelt de WRR zijn eigen werkprogramma vast, na overleg met de minister-president die hiertoe de Raad van Ministers hoort.

De samenstelling van de raad is (tot 31 december 2007):

prof. dr. W.B.H.J. van de Donk (voorzitter)

mw. prof. dr. L. Hancher

prof. dr. P.A.H. van Lieshout

mw. prof. dr. P.L. Meurs

prof. dr. B. Nooteboom

prof. dr. ir. G.H. de Vries

prof. dr. P. Winsemius

Secretaris: prof. dr. A.C. Hemerijck

Plaatsvervangend secretaris: dr. R.J. Mulder

De WRR is gevestigd:

Lange Vijverberg 4-5

Postbus 20004

2500 EA Den Haag

Telefoon 070-356 46 oo

Telefax 070-356 4685

E-mailinfo@wrr.nl

Website http://www.wrr.nl 


\section{Innovatie vernieuwd}

OPENING IN VIERVOUD 
Omslagfoto: Fotosearch.com

Omslagontwerp: Studio Daniëls, Den Haag

Vormgeving binnenwerk: Het Steen Typografie, Maarssen

$\begin{array}{ll}\text { ISBN } & 9789053565773 \\ \text { NUR } & 754 / 741\end{array}$

(C) WRR / Amsterdam University Press, Den Haag / Amsterdam 2008

Alle rechten voorbehouden. Niets uit deze uitgave mag worden verveelvoudigd, opgeslagen in een geautomatiseerd gegevensbestand, of openbaar gemaakt, in enige vorm of op enige wijze, hetzij elektronisch, mechanisch, door fotokopieën, opnamen of enige andere manier, zonder voorafgaande schriftelijke toestemming van de uitgever.

Voor zover het maken van kopieën uit deze uitgave is toegestaan op grond van artikel 16B Auteurswet 1912 jo $^{\circ}$ het Besluit van 20 juni 1974, Stb. 351, zoals gewijzigd bij het Besluit van 23 augustus 1985, Stb. 471 en artikel 17 Auteurswet 1912, dient men de daarvoor wettelijk verschuldigde vergoedingen te voldoen aan de Stichting Reprorecht (Postbus 3051, 2130 KB Hoofddorp). Voor het overnemen van gedeelte(n) uit deze uitgave in bloemlezingen, readers en andere compilatiewerken (artikel 16 Auteurswet 1912) dient men zich tot de uitgever te wenden. 


\section{WRR}

WETENSCHAPPELIJKE RAAD VOOR HET REGERINGSBELEID

Aan de Minister-president

Voorzitter van de Ministerraad

De heer mr.dr. J.P. Balkenende

Postbus 20001

2500 EA Den Haag

ons kenmerk

2008031/wvdd/lt

\section{onderwerp}

WRR-rapport nr. 80 Innovatie

vernieuwd: Opening in viervoud

\section{doorkiesnummer 070-356 4691}

\section{email}

voorzitter@wrr.nl telefax

070-356 4685

datum

9 mei 2008

Het doet mij genoegen $\mathrm{U}$ hierbij het rapport Innovatie vernieuwd; Opening in viervoud te mogen aanbieden.

Als onderdeel van een duurzame economische groeistrategie in ons land is innovatie en daarmee de voortdurende vernieuwing van onze economische structuur van doorslaggevend belang. Het tempo van vernieuwing en de benutting van het innovatiepotentieel in ons land wordt in het algemeen niet als onverdeeld gunstig beoordeeld.

Innovatie is een complex systeem waarbij het naast het creëren van nieuwe kennis en technologieën gaat om het zodanig veranderen van organisatie, management en arbeid dat kennis sneller wordt herkend, verspreid en aangewend voor nieuwe producten en diensten.

Dit rapport richt zich op hoe innovatie werkt op het niveau van actoren (mensen, organisaties, overheid) en hun interacties, in inventie, innovatie en diffusie. De analyse van de vraag hoe zo'n micro/meso benadering het Nederlandse innovatiesysteem versterkt, leidt vervolgens naar de implicaties over wat er moet gebeuren op velerlei niveaus: voor werknemers, werkgevers, bedrijven, andere organisaties en de overheid. Dit rapport legt de nadruk op de vraag waar de overheid op moet letten als het gaat om het stimuleren en faciliteren van initiatieven die innovatie tot stand brengen en die het innovatief vermogen vergroten.

Innovatie vereist dat men afstand neemt van gevestigde ideeën en praktijken. Verder zijn nieuwe omgevingen met nieuwe uitdagingen en bronnen van inspiratie nodig. Dit alles vergt opening in viervoud: Opening naar nieuwe gebieden, opening naar samenwerking, openheid voor verrassing en onzekerheid, en opening voor uitdagers. En dit vereist weer een andere mind-set.

Dit rapport kan gezien worden als complement aan twee recente WRR-rapporten, De Verzorgingsstaat Herwogen en Investeren in Werkzekerheid. Met dit drieluik benadrukt de raad de noodzaak van een bredere vernieuwings- en groeistrategie waarin vormgeving en noodzakelijke aanpassingen van de verzorgingsstaat, flexibilisering van de arbeidsmarkt met de overgang van baan- naar werkzekerheid en de versterking van het innovatief vermogen in onderlinge samenhang worden gebracht.

Volgens de procedure van de instellingswet ziet de raad graag de reactie van de ministerraad tegemoet.

De voorzitter,

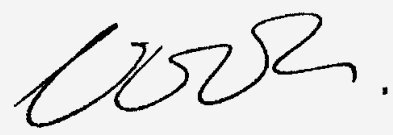

Prof.dr. W.B.H.J. van de Donk
De secretaris,

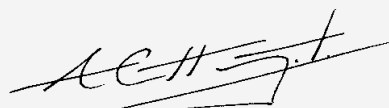

Prof.dr. A.C. Hemerijck 


\title{
INHOUDSOPGAVE
}

\author{
Samenvatting
}

Ten geleide

$1 \quad$ Inleiding 17

$\begin{array}{ll}1.1 & \text { Aanleiding van het rapport }\end{array}$

$\begin{array}{ll}1.2 & \text { Invalshoek en thematiek }\end{array}$

1.3 Probleemstelling 20

1.4 Opzet van het rapport 20

2 De noodzaak van innovatie 23

2.1 Wat is innovatie? 23

$\begin{array}{ll}2.2 & \text { Nederlandse innovatieprestaties }\end{array}$

2.3 Waarom innovatie? 28

2.4 Ontwikkeling van denken en beleid 30

2.5 Conclusie 34

3 Bronnen van innovatie $\quad 35$

3.1 Het evolutionaire perspectief 35

3.2 Kennis en leren 38

3.3 Ontdekking en toepassing 39

3.4 Open innovatie 45

$\begin{array}{lll}3.5 & \text { Vertrouwen } & 48\end{array}$

3.6 Conclusie: opening in viervoud 50

$4 \quad$ Principes voor beleid $\quad 55$

4.1 Systeemfalen $\quad 55$

$\begin{array}{lll}4.2 & \text { Marktfalen } & 58\end{array}$

$\begin{array}{lll}4.3 & \text { Overheidsfalen } & 60\end{array}$

4.4 Het sleutelgebiedenbeleid en backing winners 63

4.5 Realisatie van onbenut potentieel 66

$\begin{array}{lll}4.6 & \text { Conclusie } & 67\end{array}$

$5 \quad$ Productie en gebruik van kennis $\quad 69$

$\begin{array}{lll}5.1 & \text { Valorisatie } & 69\end{array}$

$\begin{array}{lll}5.2 & \text { Financiering van wetenschappelijk onderzoek } & 73\end{array}$

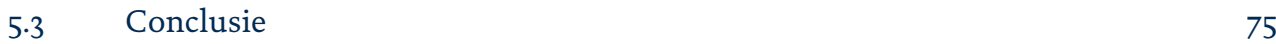

6 Ondernemerschap en innovatie 79

6.1 Ondernemerschap, innovatie en economische groei $\quad 79$

6.2 Ondernemerschap in Nederland 81

6.3 Toekomstig beleid 84

4. Conclusie 86 
$7 \quad$ Organisatie en innovatie $\quad 87$

$\begin{array}{lll}7.1 & \text { Organisatie voor innovatie } & 87\end{array}$

$\begin{array}{ll}7.2 & \text { Innovatie van organisatie }\end{array}$

$\begin{array}{lll}7.3 & \text { Innovatie van overheidsdiensten } & 92\end{array}$

$8 \quad$ Netwerk en regionaal beleid 97

$\begin{array}{lll}8.1 & \text { Netwerken } & 97\end{array}$

8.2 Regionale innovatiesystemen 99

$\begin{array}{lll}8.3 & \text { Regionaal beleid } & 101\end{array}$

9 Conclusies 105

9.1 Urgentie van innovatiebeleid 106

9.2 Anders denken over innovatiebeleid 108

9.3 Opening naar buiten 112

$\begin{array}{lll}9.4 & \text { Opening naar samenwerking } & 114\end{array}$

9.5 Opening voor verrassingen 120

$\begin{array}{lll}9.6 & \text { Opening voor uitdagers } & 122\end{array}$

$\begin{array}{lll}9.7 & \text { Publieke middelen } & 125\end{array}$

9.8 Tot slot 126

$\begin{array}{ll}\text { Literatuur } & 129\end{array}$

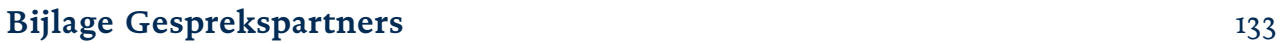




\section{SAMENVATTING}

Innovatie is van groot belang voor de welvaart in Nederland. De innovatiecapaciteit van Nederland loopt echter achter bij die van andere Europese landen. De sterke positie van Nederland in wetenschappelijke kennis en patenten wordt niet omgezet in een evenredig sterke positie in innovatie en productiviteitsgroei.

Dit is een precaire situatie gezien de toenemende globalisering en de afnemende inzet van arbeid in Nederland. De toenemende globalisering maakt het noodzakelijk uit te blinken in die producten en diensten waarmee Nederland beter waarde kan toevoegen dan andere landen. Dit betekent dat het Nederlandse bedrijfsleven en de overheid zich moeten inzetten voor het creëren van nieuwe ideeën, het commercialiseren van nieuwe ideeën en het verspreiden en gebruiken van innovaties. Om de teruglopende inzet van arbeid te compenseren is het verhogen van de arbeidsproductiviteit van groot belang. Dit kan gerealiseerd worden door arbeid beter te organiseren.

Tot nu toe heeft het innovatiebeleid zich vooral gericht op het scheppen van gunstige voorwaarden voor innovatie, met name het inzetten van middelen en regelgeving met betrekking tot onderwijs, onderzoek, intellectueel eigendom, belasting en subsidies, concurrentie en internationale handel. Het creëren van voorwaarden voor innovatie op macro-economisch niveau is weliswaar van groot belang, maar het is niet voldoende voor de daadwerkelijke totstandbrenging en verspreiding van innovaties. Innovatieprocessen spelen zich immers grotendeels af op het microniveau, in bedrijven en andere organisaties. De mogelijkheden voor overheidsbeleid om dergelijke innovatieprocessen te verbeteren zijn beperkt. Het huidige innovatiebeleid is grotendeels gebaseerd op een lineair model van innovatie waarbij wetenschap en technologie centraal staan. De Nederlandse paradox - sterk in de productie van wetenschappelijke kennis en patenten, maar niet in het toepassen en op de markt brengen hiervan - kan ook niet worden opgelost door macro-economisch overheidsbeleid.

De meeste kansen voor het verbeteren van de innovatiecapaciteit van Nederland lijken te liggen in het veranderen van de institutionele en organisationele condities van innovatieprocessen op meso- en microniveau. Hier ligt een potentieel dat door een vernieuwd innovatiebeleid ontsloten kan worden. Dit rapport wil laten zien hoe innovaties tot stand komen en welke organisationele en institutionele condities dit proces bevorderen of belemmeren. Er is in de afgelopen jaren veel onderzoek verricht naar innovatie en de inzichten hiervan zijn nog te weinig gebruikt als fundering van keuzes voor overheidsbeleid met betrekking tot innovatie. Dit rapport geeft hier de nodige handvatten voor.

Centraal in dit rapport staat de cyclus van innovatie. Deze cyclus specificeert de essentiële processen van innovatie, zonder daarbij te claimen dat de uitkomsten daarvan voorspeld kunnen worden. Exploratie van nieuwe mogelijkheden en exploitatie van bestaande ideeën volgen elkaar op in deze cyclus. Innovatie is per 
definitie onvoorspelbaar en beleid met betrekking tot innovatie moet hier dan ook rekening mee houden. Deze inherente onzekerheid betekent dat effectief innovatiebeleid onmogelijk vooraf de gewenste doelen en middelen kan vastleggen. Ook betekent dit dat rekening gehouden moet worden met vele mislukkingen, die noodzakelijk zijn om tot waardevolle vernieuwingen te komen. Sommige van deze innovaties zullen bedreigend zijn voor gevestigde partijen, omdat ze de verkoop van hun producten bedreigen en ze hun kennis en vaardigheden niet gemakkelijk op andere manieren kunnen inzetten. Wanneer een inventie succesvol wordt toegepast in nieuwe producten of organisatieprocessen (innovatie), wordt nieuwe economische waarde gecreëerd. Op een zeker moment zal de markt verzadigd raken en is het noodzakelijk om nieuwe contexten op te zoeken om nieuwe waarde te creëren met het al succesvol toegepaste idee. Vaak moet de innovatie gecombineerd worden met bestaande producten en praktijken in deze nieuwe contexten, dit wordt mogelijk gemaakt door samenwerking met partijen uit deze nieuwe contexten die vaak anders denken. Als deze cognitieve afstand tussen partijen overbrugd wordt, kan ze leiden tot volstrekt nieuwe ideeën - nieuwe combinaties - die weer het begin van een volgende cyclus vormen.

Het rapport is een pleidooi voor meer openheid, daar waar sluiting ten opzichte van onzekerheid in innovatie (1), uitdagers (2), nieuwe contexten (3) en samenwerking met andersdenkenden (4) overheerst. In tegenstelling tot beleid dat zich richt op de inzet van schaarse publieke middelen voor (door de overheid uitgekozen) bedrijfstakken, is dit rapport vooral een pleidooi om te kiezen voor openheid. Deze openheid is een essentiële voorwaarde voor de creatie van nieuwe ideeën en het tot ontwikkeling laten komen van innovaties. Deze openheid is allesbehalve vanzelfsprekend: ze wordt bedreigd door de neiging van overheden om verantwoording vooraf op specifieke inhoudelijke doelen te eisen, beleid in samenspraak met gevestigde partijen vorm te geven en met name middelen in te zetten voor deze gevestigde partijen, programma's op te stellen beperkt tot specifieke sectoren, regio's, tot de nationale context en zich alleen te richten op het functioneren van huidige markten. De overheid zal zich bewust moeten zijn van deze neiging tot sluiting en actief beleid moeten voeren om opening te realiseren of te verdedigen. In het bedrijfsleven geldt ook dat de openheid naar buiten (bijvoorbeeld door werknemers die inventies willen toepassen in bedrijfsvreemde contexten) en de openheid voor samenwerking nog te wensen overlaat. Hier kan de overheid een indirecte rol kunnen spelen door deze openheid te faciliteren. Een directe rol is weggelegd voor de overheid als het gaat om innovaties binnen de overheidsorganisatie en innovatie in publieke sectoren. In het eerste geval zijn er nog veel mogelijkheden tot verbetering door gebruik te maken van nieuwe organisatievormen. In het tweede geval staat de overheid voor grote opgaven die niet (primair) door de markt geleid worden. Het betreft hier investeringen in innovaties in sectoren zoals zorg, milieu, onderwijs, infrastructuur, veiligheid en water. De overheid moet hier de leiding nemen in innovatie. Hier geldt ook dat door het fundamenteel onzekere karakter van innovatie men het risico van verkeerde keuzen moet accepteren om tot waardevolle vernieuwingen 
te komen. Tevens moet de overheid zich inzetten voor openheid voor uitdagers en samenwerking buiten voor de hand liggende sectoren, regio's en de landsgrens.

Dit alles betekent een vernieuwd innovatiebeleid en een visie op Nederland als een plaats waar andersdenkenden elkaar ontmoeten. Deze ontmoeting is noodzakelijk voor waardecreatie door het ontwikkelen van nieuwe producten en door productie, distributie en consumptie op nieuwe manieren te organiseren. Dit ligt in het verlengde van de traditionele functie van Nederland als knooppunt van goederenstromen, als knooppunt van stromen van mensen met hun kennis en hun behoefte aan kennis. Dit vergt ook experimenten met nieuwe vormen van organisatie om waarde te creëren in nieuwe internationale omstandigheden. Wellicht kunnen de Nederlanders opnieuw en zelfs op een breder terrein dan in het verleden de rol van intermediair vervullen en anderen helpen hun cognitieve afstand te overbruggen. Dat vergt dat wij ons vermogen tot samenwerking met andersdenkenden verder ontwikkelen, zodat we grote cognitieve afstanden kunnen overbruggen en nieuwe waarden kunnen creëren. 




\section{TEN GELEIDE}

Dit rapport is voorbereid door een interne projectgroep van de WRR. Voorzitter was prof. dr. Bart Nooteboom, lid van de raad. Verder bestond deze projectgroep uit de volgende stafleden: dr. Gerard de Vries (projectcoördinator tot december 2007), drs. Paul van Leeuwe (projectcoördinator vanaf december 2007), dr. Robert Went, dr. Gerrit Kronjee, dr. Erik Stam en drs. Niels Feitsma. Vanuit het ministerie van Economische Zaken werd aan het project deelgenomen door drs. Anne Reitsma en drs. Karen de Ruijter.

Ten behoeve van de samenstelling van dit rapport is een aantal (externe) onderzoeken gedaan. Deze onderzoeken zijn gepubliceerd in de WRR-verkenning die separaat met dit rapport wordt gepubliceerd: B. Nooteboom, E. Stam (red.), Micro-foundations for Innovation Policy, WRR-verkenningen 18, Amsterdam: Amsterdam University Press. In deze verkenning zijn bijdragen opgenomen van dr. Ron Boschma, prof. dr. Neil Anderson, dr. Rosina Gasteiger, drs. Leo van der Geest, drs. Lars Heuts, prof. dr. Patrick Kenis, dr. Gerrit Kronjee, prof. dr. Marius Meeus, prof. dr. Bart Nooteboom, prof. dr. Leon Oerlemans, dr. Erik Stam, dr. Gerard de Vries en dr. Robert Went.

Tijdens de voorbereiding van dit rapport is een aantal bijeenkomsten gehouden. Er is toen, naast de voornoemde auteurs van de Verkenning gesproken en van gedachten gewisseld met onder anderen Alexander Rinnooy Kan (SER), Paul Schnabel (SCP), Georg Gelauff (СРB), Hans de Groene (ministerie van Economische Zaken), Alfred Kleinknecht (TU Delft), Wim Vanhaverbeke (TUe), Jan Lambooij (UVA), Luc Soete (UM), Arjen van Witteloostuijn (Universiteit Antwerpen), Jan-Peter van de Toren (Innovatieplatform), Arnoud Boot (UVA), Wim de Ridder (SMO), Henk van der Kolk (FNV), Frans van der Zee (TNO), Pieter de Bruijn (ministerie van Economische Zaken), Joris Meijaard (EIM), Jeroen de Jong (EIM), Roderik Ponds (RPB, UU), Otto Raspe (RPB), Hans Bakker (ministerie van Economische Zaken), Stephan Raes (ministerie van Economische Zaken), Nora van der Wenden (ministerie van Economische Zaken), Marije Schouwstra (ministerie van Economische Zaken), Eric Schmieman (ministerie van Economische Zaken), Peter Wansink (ministerie van Onderwijs, Cultuur en Wetenschap), Rens van Tilburg (AWT), Sijas Akkerman (Innovatieplatform), Frank Eetgerink (NV Oost), Victor Gilsing (TU/e), Sven Hemlin (Göteborg University), Gert-Jan Hospers (Universiteit Twente), Richard Slotman (Stichting Innovatie Alliantie), Evert-Jan Visser (UU), Ger Vos (Innovatienetwerk Agro), en Rene Wintjes (UNU-Merit, UM). Wij zijn hen zeer erkentelijk.

De projectgroep heeft verder kunnen profiteren van een serie interviews die gevoerd zijn met mensen uit het openbaar bestuur, het hoger onderwijs en het bedrijfsleven. De namen van de geïnterviewde personen zijn terug te vinden in een bijlage van dit rapport. Wij danken hen voor hun medewerking.

Wim B.H.J. van de Donk, voorzitter WRR 


\subsection{AANLEIDING VAN HET RAPPORT}

Innovatie is van groot belang voor een welvarend Nederland. De innovatiecapaciteit van Nederland loopt echter achter bij die van andere Europese landen. Dit is, gezien de toenemende globalisering en de afnemende inzet van arbeid in Nederland, een precaire situatie. De toenemende globalisering maakt het noodzakelijk om uit te blinken in datgene waar men in Nederland beter waarde kan toevoegen dan andere landen. Door de vergrijzing zal een intensievere benutting van de potentiële beroepsbevolking, in tegenstelling tot de afgelopen decennia niet langer de belangrijkste bron van economische groei kunnen zijn. Dit betekent dat het Nederlandse bedrijfsleven en de overheid zich moeten inzetten voor het creëren van nieuwe ideeën, het commercialiseren van nieuwe ideeën en het verspreiden en gebruiken van innovaties.

Al lange tijd is er beleid inzake wetenschap en technologie. Sinds het Lissabonakkoord (2000) en de instelling van het Innovatieplatform door het kabinetBalkenende II in 2003 is een meer geprononceerd innovatiebeleid ingezet. Hoewel de macro-economische condities in ons land in internationaal perspectief bezien een gunstige uitgangspositie vormen, hebben deze tot op heden niet geresulteerd in een vergelijkbare gunstige positie van het Nederlandse innovatiesysteem. Dit illustreert dat het van groot belang is om naast solide macro-economische verhoudingen ook de achterliggende innovatieprocessen onder de loep te nemen. Hierdoor kan men bovendien bouwstenen verkrijgen voor versterking van een op de ontwikkeling van innovaties gericht beleid.

De WRR is in oktober 2006 een project gestart om het innovatieproces nader te bestuderen, gebruikmakend van inzichten in de praktijk en van recente wetenschappelijke literatuur over innovatie. Die activiteiten hebben in eerste aanleg geleid tot een uitgebreide WRR-verkenning ${ }^{1}$ met analyses van processen van leren, samenwerken, ondernemerschap, wetenschap en toepassing, organisatie, netwerken en regionaal beleid. In dit rapport, dat voortbouwt op de verkenning, zal blijken dat daarbij voor de overheid een stimulerende en vaak ook coördinerende rol is weggelegd. Deze overheidsrollen worden verderop nader gepreciseerd. Dit rapport is complementair aan eerder verschenen WRR-rapporten over de lerende overheid (WRR 2006a), de verzorgingsstaat (WRR 2006b) en werkzekerheid (WRR 2007).

\subsection{INVALSHOEK EN THEMATIEK}

Om inzicht in innovatieprocessen te verkrijgen is kennis nodig van het gedrag van actoren op micro-/mesoniveau, dat wil zeggen op het niveau van mensen, bedrijven en organisaties, inclusief vormen van samenwerking daartussen. Ook is kennis nodig van processen van leren, innoveren, ontwikkelen, toepassen, 
verspreiden en daarvan opnieuw leren. Deze inzichten komen in de huidige benadering van innovatie en het beleid dat daarop is gestoeld vooralsnog bescheiden naar voren. Dat is een probleem. Dit rapport reikt hiervoor een oplossingsrichting aan: het laat zien hoe door gebruikmaking van micro-/meso-inzichten van het innovatieproces de kwaliteit en opbrengst van het innovatiesysteem kunnen worden verbeterd. Dit biedt openingen en oriëntatiepunten voor het overheidsbeleid. Dit vormt voor de raad de reden om, gebruikmakend van de bevindingen uit de hiervoor genoemde verkenning, dit advies aan de regering uit te brengen.

\section{Thema 1: innovatie als systeem}

Bij de behandeling van innovatie staat in dit rapport een aantal thema's centraal. Het eerste thema is innovatie bezien als samenhangend systeem. Dit systeem is veel breder dan wetenschap en technologie, die zich louter toeleggen op de productie en toepassing van kennis. Het innovatiesysteem omvat daarnaast processen van uitvinding, innovatie en diffusie, binnen en tussen organisaties. Daarbij gaat het om ondernemerschap, marketing, organisatie en om de overheid zelf.

\section{Thema 2: innovatie als cyclisch proces}

Een volgend thema beziet het innovatieproces als combinatie van de ontwikkeling van het nieuwe ('exploratie') en efficiënte toepassing/verbetering van het bestaande ('exploitatie'). Voor de efficiency op korte termijn zijn exploitatievaardigheden essentieel, terwijl voor langetermijnontwikkeling exploratievaardigheden noodzakelijk zijn. Die exploratie en exploitatie moeten worden gecombineerd. Dat is een paradoxale opdracht, omdat zij verschillende eisen stellen aan organisatie, werkwijze en mentaliteit. Dit rapport introduceert een cyclisch innovatiemodel waaruit de wisselwerking blijkt tussen exploitatie die resulteert uit exploratie en waarbij vervolgens nieuwe exploratie ontstaat uit verschuivende en evoluerende exploitatie.

\section{Thema 3: innovatie als evolutie}

Een volgend thema is de vraag hoe en door wie gekozen moet worden in welke richting naar vernieuwing wordt gezocht. Hierbij speelt ook de vraag hoe besloten wordt over het inzetten van middelen, in aanmerking genomen de onzekerheid en onvoorspelbaarheid die innovatie eigen zijn. Hiervoor is het nuttig het innovatieproces te bezien vanuit een evolutionair perspectief. Dat geeft aan hoe nieuwe dingen kunnen ontstaan zonder doelgericht ontwerp vooraf. Het evolutionair perspectief helpt te begrijpen (1) dat er bronnen moeten zijn van diversiteit aan ideeën, (2) die efficiënt maar ook in alle openheid worden onderworpen aan selectie op levensvatbaarheid, en (3) bij succes efficiënt en breed worden toegepast. Vooral deze brede toepassing, in het gebruik van bestaande kennis ('diffusie'), produceert welvaart. Inventie is nodig, maar innovatie is vooral toepassing. Het probleem zit hem dan vooral in de frase 'efficiënte selectie, maar in alle openheid'. Dit is een paradoxale eis, waarvan de complexiteit op enigerlei wijze in het innovatiebeleid onderdak moet zien te krijgen. 


\section{Thema 4: inzet van publieke middelen voor innovatie}

Daar waar de overheid bij bepaalde innovaties is betrokken door de inzet van publieke middelen vormen de volgende voorwaarden het uitgangspunt: (1) de bevoegde innovatie betreft een kwestie van maatschappelijk belang en heeft maatschappelijke prioriteit; (2) zonder interventie van de overheid komt de innovatie niet tot stand (het principe van 'additionaliteit'); (3) waar men succes niet kan voorspellen moet men accepteren dat falen, in de zin van het niet behalen van gewenste of verwachte uitkomsten, erbij hoort. Een veelgehoorde zinspreuk is dat bij innovatieactiviteiten de optie van mislukken een voorwaarde is voor het behalen van succes.

Nauw verbonden hieraan is hoe een overheid kan bevorderen dat andere actoren dan de overheid, vooral in het bedrijfsleven, keuzes maken en middelen inzetten, zodanig dat die innovatie opleveren. De vraag is dan waar de overheid op moet letten als het gaat om het stimuleren en faciliteren van die initiatieven die het innovatief vermogen vergroten. Marktwerking is slechts een deel van het verhaal. Concurrentie kan een prikkel geven voor innovatie, maar uit onderzoek blijkt dat er vaak meer nodig is. Aan bestaande markten zijn soms instituties verbonden die innovatie in de weg kunnen zitten. De overheid moet dan zorgen voor institutionele aanpassing van bestaande markten of voor een evolutie in de richting van nieuwe markten.

\section{Vierledige overheidstaak}

Een nadere uitwerking van deze thema's wijst erop dat de overheid vooral moet zorgen voor opening en wel voor opening in viervoud.

(1) Opening voor samenwerking tussen organisaties, om verbindingen te leggen tussen actoren met het oog op nieuwe combinaties (niet alles zelf in de eigen organisatie willen doen). Samenwerking is lastig en gaat vaak fout maar is wel cruciaal. Daarvoor is vertrouwen nodig, maar elkaar vertrouwen is moeilijk. Het is van belang te begrijpen hoe dit werkt en wat de rol van de overheid daarbij kan zijn. Dit hoeft niet per se te betekenen dat de overheid zelf bemiddelt in samenwerking. Het kan ook zo zijn dat zij commerciële bemiddeling stimuleert of obstakels voor samenwerking weghaalt.

(2) Opening voor verrassing en mislukking in innovatietrajecten (programma's, projecten). Opening voor verassing en mislukking is nodig vanwege de onvoorspelbaarheid van innovatie, maar vormt een lastig vraagstuk bij door de overheid gesubsidieerde trajecten: hoe kan men opening voor verrassing en mislukking rijmen met publieke verantwoording?

(3) Opening voor diversiteit van nieuwe ideeën en initiatieven van uitdagers van buiten de gevestigde orde. Kennis en ideeën zijn wijdverspreid in de samenleving en zijn daar veel rijker dan beleidsinstanties zelf kunnen verzinnen of overzien. Waar het om gaat is ideeën te presenteren, dingen te doen die niet direct stroken met de common sense en de gevestigde orde. Concreet betekent dit dat de overheid zich in haar innovatiebeleid meer moet richten op nieuwe bedrijven en minder op de gevestigde spelers.

(4) Opening over de grenzen van gebieden, om gebruik te maken van ideeën en 
activiteiten aldaar (niet alles zelf willen doen in eigen bedrijfstak, land of regio). Dit impliceert bijvoorbeeld dat de Nederlandse overheid bedrijven stimuleert om in nieuwe markten en andere landen of bedrijfstakken impulsen voor innovatie op te doen.

\subsection{PROBLEESTELLING}

Gelet op het feit dat de innovatiecapaciteit van Nederland een teleurstellende ontwikkeling vertoont, terwijl demografische en mondiale ontwikkelingen juist een extra versterking nodig maken en gelet op het feit dat de macro-economische randvoorwaarden een dergelijke zwakke prestatie kunnen verklaren noch verbeteren, wordt in dit rapport bezien hoe door gebruikmaking van micro-/mesoinzichten in het innovatieproces de kwaliteit van het Nederlandse innovatiesysteem kan worden verbeterd. De probleemstelling luidt als volgt:

Hoe kan overheidsbeleid met betrekking tot de institutionele en organisationele omstandigheden die van invloed zijn op innovatieprocessen de innovatiecapaciteit van Nederland verbeteren?

De doelstelling van het rapport is om wetenschappelijk inzicht te verkrijgen in de werking van innovatieprocessen in het algemeen en in de werking van het huidige innovatiesysteem in Nederland in het bijzonder, en op basis hiervan richting te geven aan toekomstig innovatiebeleid in Nederland. We komen in dit rapport met een analyse van de vraag hoe het innovatiesysteem vanuit micro-/meso-inzichten op samenhangende wijze kan worden verbeterd door overheidsbeleid. Die heeft tal van implicaties op verschillende niveaus voor werknemers, ondernemers, werkgevers, bedrijven en andere organisaties, netwerken en regio's en de decentrale en centrale overheid. Niet altijd is er aanleiding voor overheidsbeleid, innovatieprocessen spelen zich tenslotte vooral af in niet-overheidssectoren. Toch zullen we onze aanbevelingen toespitsen op het rijksbeleid. Het is echter naar de mening van de raad goed dat de overheid ook weet wat op andere niveaus de implicaties voor beleid en gedrag zijn in de ontwikkeling van haar beleid. En de overheid kan wellicht ook op andere niveaus, waar geen aan-leiding is voor nieuw eigen beleid van overheidszijde, bijdragen aan bewustwording.

\subsection{OPZET VAN HET RAPPORT}

Dit rapport richt zich op de vraag hoe innovatie werkt op het niveau van actoren (mensen, organisaties, overheid) en hun interacties. Vervolgens is de vraag hoe de overheid het innovatieproces kan faciliteren en stimuleren, zonder zelf de inhoud te bepalen.

De opzet van het rapport is als volgt. Eerst volgen drie hoofdstukken met definities, concepten en theorieën betreffende innovatie en innovatiebeleid. Die worden in de volgende hoofdstukken gebruikt in de analyse van principes voor 
beleid en van verschillende onderdelen van het innovatiesysteem, die vervolgens uitmonden in beleidsaanbevelingen.

Hoofdstuk 2 is beschrijvend van aard. De volgende vragen komen daarin aan de orde: wat is innovatie; wat zijn de rol en noodzaak ervan in de (internationale) economie; hoe presteert Nederland qua innovatie; waar liggen de zwakheden; en hoe heeft het denken over innovatiebeleid zich ontwikkeld? Dit leidt tot de conclusie dat de prestaties van Nederland ondermaats zijn en dat bevordering van innovatie nodig is.

Hoofdstuk 3 presenteert enkele theoretische en conceptuele grondslagen van de bronnen van innovatie die door beleid kunnen worden aangeboord. Dit betreft vooral principes van evolutie, kennis, processen van leren en ontdekking, de combinatie van exploratie en exploitatie en de rol van vertrouwen in processen van innovatie. Hier komt het concept van het innovatiesysteem naar voren met naast wetenschap en technologie velerlei niet-technologische aspecten, waarin verbindingen tussen elementen van het systeem een cruciale rol spelen als basis voor processen van innovatie. Daardoor wordt duidelijk dat innovatiebeleid veel verder dient te gaan dan wetenschap en technologie.

Hoofdstuk 4 behandelt de vraag waarom beleid nodig is en geeft enkele generieke principes voor innovatiebeleid. Deze principes komen voort uit een analyse van tekortkomingen of blokkades in het innovatiesysteem (systeemfalen), in marktwerking en in het functioneren van de overheid zelf.

In de hoofdstukken 5 tot en met 8 geven we een nadere uitwerking van de beleidsanalyse met betrekking tot de belangrijkste onderdelen van het innovatiesysteem: productie en gebruik van kennis (hoofdstuk 5), ondernemerschap (hoofdstuk 6), organisatie (hoofdstuk 7), en netwerken en regionale innovatiesystemen (hoofdstuk 8). De thema's opening en combinatie van exploratie en exploitatie komen daarin steeds terug en vormen een conceptuele verbinding. Het rapport sluit af (hoofdstuk 9) met conclusies en beleidsaanbevelingen. 


\section{NOOT}

1 Deze verkenning, die separaat aan dit rapport verschijnt, is in het Engels gesteld, met de titel Micro-foundations for innovation policy. Dit om aansluiting te vinden bij het internationale debat over innovatie en innovatiebeleid, met name in de EU. Dit rapport bevat een bijlage die de inhoudsopgave van de verkenning weergeeft, bestemd voor lezers die dieper willen ingaan op het onderwerp. 
In het vorige hoofdstuk werd gesproken van een teleurstellende ontwikkeling van het innovatieve vermogen van de Nederlandse economie. Dit hoofdstuk maakt die ontwikkeling aanschouwelijk en geeft invulling aan het begrip innovatie. De volgende vragen worden beantwoord: wat is innovatie (2.1); wat zijn het maatschappelijk en economisch nut en de noodzaak van innovatie (2.2); hoe presteert Nederland in innovatie en wat zijn de zwakheden (2.3); en hoe hebben inzichten en beleid ten aanzien van innovatie zich ontwikkeld en waar behoeven ze verdere aanpassing (2.4)?

\subsection{WAT IS INNOVATIE?}

Letterlijk betekent innovatie vernieuwing, maar dat is voor velerlei uitleg vatbaar. Innovatie is een proces en ook de uitkomst daarvan. Innovatie als uitkomst is een nieuwe functionaliteit of een nieuwe manier om een bestaande functie te vervullen (bijvoorbeeld digitale fotografie). Dat is breder dan een nieuw product of proces in de markt en omvat ook innovaties in de publieke sector (bijvoorbeeld het via internet aanbieden van overheidsdiensten). Het proces omvat de ontwikkeling van een nieuwe vondst (inventie), de succesvolle toepassing daarvan (innovatie als uitkomst) en de brede verspreiding van innovaties in de samenleving (diffusie). Na de uitvinding van digitale beelden moesten de bijbehorende elektronica en optica op een adequate manier worden ingebouwd in een camera, met een bijpassende methode voor het afdrukken van digitale foto's, moesten toeleveranciers zich richten op de levering van benodigde onderdelen en moesten consumenten wennen aan het gebruik.

Aanvankelijk werd het innovatieproces gezien als lineair, met onderzoek en ontwikkeling (R\&D) als input en nieuwe producten en processen als output. Meer recent is er aandacht gekomen voor het feit dat er velerlei terugkoppelingen zijn. Zo worden tijdens het toetsen, ontwikkelen en toepassen van innovaties bijvoorbeeld lessen getrokken voor aanpassing en differentiatie. Of krijgt men in het proces van diffusie inspiratie en doet men ideeën op voor nieuwe vondsten. Waar het vanuit een economische invalshoek om gaat is de relatie tussen de voortbrenging van kennis en de voortbrenging van producten.

\section{Box 2.1 Inventie, innovatie en diffusie}

De aandacht van beleid en publiek gaat bij innovaties vaak uit naar spectaculaire vondsten, maar die zijn schaars. Er is veel meer innoverende activiteit in de brede uitwaaiering van toepassingen en daar ligt ook het nut van de innovatie voor de economische groei. Innovatie gebeurt vaker op basis van bestaande kennis en technologie dan op basis van nieuwe. Dat geldt vooral voor procesinnovaties, maar ook gemiddeld de helft van succesvolle productinnovaties komt voort uit imitatie 
(Jaumotte and Pain 2005: 25). Diffusie van innovaties is daarom evenzeer van belang, en wellicht meer, dan de creatie ervan.

De vraag rijst ook waarom we ons eigenlijk zouden moeten inzetten voor het creëren van vondsten (inventie), als het economische rendement voortkomt uit de toepassing (innovatie) en verspreiding (diffusie). Waarom besteden we eigenlijk zo veel aandacht aan R\&D? Waarom gebruiken we, zeker als klein land, niet de resultaten van het onderzoek van anderen? En als we dan op sommige gebieden voorop willen lopen, op welke dan wel en welke niet?

\section{Nieuwe of minder nieuwe innovaties}

Innovatie kan meer of minder nieuw zijn. In de statistieken van de EU voor innovatie (de Community Innovation Survey, CIS) wordt een onderscheid gemaakt tussen 'nieuw voor een bedrijf' (imitatie), 'nieuw voor de markt van een bedrijf' en 'nieuw voor de wereld'. Nieuw alleen voor een bedrijf is nauwelijks nieuw, zou men denken, maar toepassing van iets nieuws kan binnen een bedrijf radicale veranderingen vergen, bijvoorbeeld van kennis en opleiding, apparaten of instrumenten, en organisatie.

\section{Radicale of incrementele innovaties}

Innovatie kan meer radicaal zijn, in de vorm van het toepassen van meer fundamenteel nieuwe principes, ontwerpen of inzichten, of zij kan meer incrementeel zijn, in de vorm van aanpassingen van reeds bestaande innovaties. De toepassing van een bestaande technologie voor een nieuwe functie, bijvoorbeeld, is deels incrementeel (bestaande technologie) en deels fundamenteel (nieuwe functie). Denk bijvoorbeeld aan de bekende nieuwe combinatie van bestaande informatieen communicatietechnologieën in internet, met revolutionaire gevolgen.

\section{Innovatie als 'creative destruction'}

De beroemdste van de innovatie-economen, Joseph A. Schumpeter, kenmerkte innovatie als 'creatieve destructie', waarbij oude producten, (productie)methoden en productiemiddelen worden vervangen door 'nieuwe combinaties'. Er is een samenhang tussen radicale en destructieve innovatie, maar die samenhang is niet algemeen. Een innovatie kan radicaal zijn zonder erg destructief te zijn en een destructieve innovatie kan beperkt radicaal zijn. Radicale innovatie kan meer of minder competence destroying zijn, dat wil zeggen het nut afbreken van bestaande competenties van bedrijven, marktposities en structuren (bijvoorbeeld distributiekanalen) of bestaande investeringen (in technologie, opleiding, etc.).

\section{Box 2.2 Digitale fotografie}

De reeds genoemde digitale fotografie is een nieuwe manier om een bestaande functie te vervullen, maar de innovatie is redelijk radicaal en creatief-destructief. $\mathrm{Zij}$ is radicaal in het toevoegen van nieuwe functies zoals digitale bewerking van foto's en het maken en verzenden van foto's per mobiele telefoon. Zij maakt het mogelijk om visuele en andere media te mixen in computers en internet. Zij is destructief in het wegdrukken van de markt van chemische films en het ontwikkelen 
en afdrukken daarvan en van analoge camera's. Burgers begeven zich met hun mobiel met camera op het terrein van persfotografie en andere rapportage en gaan bewijsmateriaal leveren aan de politie. De innovatie biedt ook de basis voor nieuwe vormen van kunst en ontwerp.

Naarmate een innovatie meer bestaande competenties dreigt te vernietigen, zullen de bestaande bedrijven niet onmiddellijk geneigd zijn de innovatie en diffusie ter hand nemen. Bedrijven die meer schade ondervinden van het verliezen van hun verworvenheden dan winst van de nieuwe mogelijkheden, zullen de ontwikkeling zelfs willen tegenhouden of uitstellen, als ze daar de kans toe krijgen. In die gevallen moet men het dus meer hebben van nieuwkomers. Naarmate men het innovatiebeleid meer richt op het voortbouwen op successen uit het verleden zal de innovatie meer gaan in de richting van het behoud van bestaande basiscompetenties en bijbehorende instituties. Die innovatie kan dan nog radicaal zijn, maar is minder ingrijpend.

Schumpeter (1934) gaf al aan dat innovatie niet alleen plaatsvindt in technologie, maar ook in markten (voor producten en voor productiemiddelen) en in organisatie. Niettemin lag traditioneel de aandacht voor innovatie vooral in technologie. In de ontwikkeling van het denken over innovatie en innovatiebeleid zien we dat in hoog tempo een verbreding van het begrip innovatie plaatsvindt. Dit heeft de nodige implicaties voor het overheidsbeleid.

\subsection{NEDERLANDSE INNOVATIEPRESTATIES}

Hoe presteert Nederland op het gebied van innovatie? Voor beantwoording van deze vraag kijken we naar diverse indicatoren. Het zal blijken dat Nederland beneden peil presteert, zeker als we het ontwikkelingsniveau waarop Nederland zich bevindt in aanmerking nemen.

\section{Productiviteit}

Een eerste indicatie van ondermaatse prestaties is een lager dan gemiddelde ontwikkeling van productiviteit binnen de EU (zie tabel 2.1).

Tabel 2.1 BBP per gewerkt uur (gemiddelde jaarlijkse procentuele toename)

\begin{tabular}{|l|c|c|} 
& $\mathbf{1 9 8 0 - 1 9 9 5}$ & $\mathbf{1 9 9 5 - 2 0 0 6}$ \\
Duitsland & 2.4 & 1.7 \\
Frankrijk & 2.5 & 1.8 \\
Verenigd Koninkrijk & 2.6 & 2.0 \\
Finland & 3.0 & 2.5 \\
Nederland & 1.7 & 1.5 \\
Gemiddelde EU-15 & 2.3 & 1.8 \\
\hline
\end{tabular}

Bron: GGDC/ТСв Total Economy Database, January 2007, www.ggdc.net zie tabel 2.7. 
Terwijl Nederland zich qua bbp per hoofd in de hoogste regionen van de EU-landen bevindt, zitten we qua productiviteitsontwikkeling rond het EU-gemiddelde. Waaraan is dit tekort toe te schrijven? Productiviteit is de resultante van velerlei factoren. Uit de WRR-verkenning bij dit rapport (De Vries 2008) blijkt dat uit internationaal onderzoek kan worden afgeleid dat ongeveer de helft van de stijging van de arbeidsproductiviteit met innovatie van doen heeft (de andere helft vloeit voort uit het onderwijsniveau en de benutting van kapitaal). In dat type onderzoek representeert innovatie een residu, zodat de samenstellende delen ervan niet zijn gedetermineerd.

\section{Innovativiteitsindicatoren}

Er zijn tal van indicatoren van innovatie ontwikkeld. In de European Innovation Scoreboard staat Nederland op de elfde plaats en behoort het niet tot de leiders in innovatie. In een rangordening van de Economist Intelligence Unit staat Nederland op de dertiende plaats. Nederland staat op de twintigste plaats als aantrekkelijke locatie voor buitenlandse R\&D (De Vries 2008). Ditzou een groot deel van de verklaring kunnen zijn voor het lage niveau van private R\&D in Nederland in vergelijking met andere OECD-landen (Erken and Ruiter 2005: 78). Uit een CBS-onderzoek (2007) blijkt Nederland op zes indicatoren van innovativiteit lager te scoren dan het gemiddelde van de EU, en op de resterende twee komt ons land nauwelijks boven het gemiddelde uit en blijft daar beduidend achter bij de top (zie figuur 2.1). Nederland scoort alleen bovengemiddeld op de indicatoren voor octrooien.

\section{Figuur 2.1 Innovatie in Nederland en de EU}

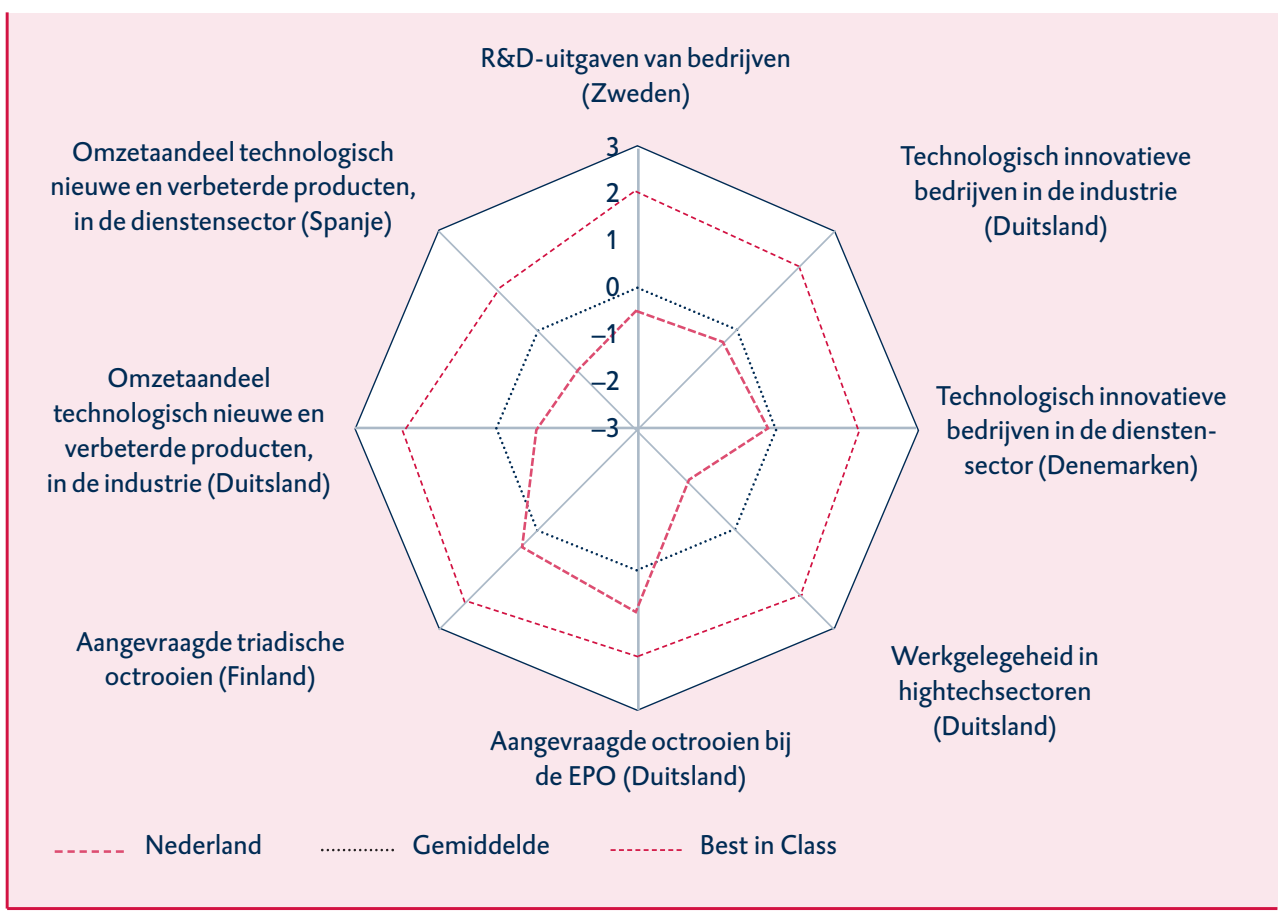

Bron: CBS (2007): 23 
Wat zit er achter deze tekorten? Als het met octrooien goed gaat maar niet met de vertaling daarvan in omzetaandelen van nieuwe producten, in industrie en dienstverlening (zie figuur 2.1), dan hebben we wat genoemd wordt een 'innovatieparadox': Nederland is goed in onderzoek maar niet in innovatie. De innovatieparadox wordt geweten aan een tekort aan 'valorisatie', dat wil zeggen de toepassing van respectievelijk wetenschappelijke en technologische kennis. Verbetering van die toepassing speelt dan ook een belangrijke rol in het huidige innovatiebeleid. Het probleem, en de oplossing, wordt dus gezocht in het deel van het innovatiesysteem dat zich bezighoudt met de toepassing van kennis en technologie. Zo meldt de OECD een 'Dutch paradox' in "an excellent record in knowledge creation, but a mediocre record in innovation activity, which is defined as the successful development and application of new knowledge in new product and/or processes" (OECD 2005c: 104).

\section{Ondernemerschap}

De relatie tussen wetenschap en toepassing speelt zich vooral af in relaties tussen wetenschap en technologische R\&D van gevestigde grote bedrijven. Het probleem kan ook liggen in een gebrek aan ondernemerschap dat actief is in innovatie.

Zowel grote als kleine bedrijven zijn van belang voor economie en innovatie. Het ene is sterk waar het andere zwak is en het moet in beleid gaan om de complementariteit tussen de twee. Hoe zit het met innovatief ondernemerschap in Nederland? Op het eerste gezicht lijkt dat goed te gaan: het aantal nieuwe bedrij-

Figuur 2.2 Innovatie-outputs van het Мкв in Nederland, 1999-2007

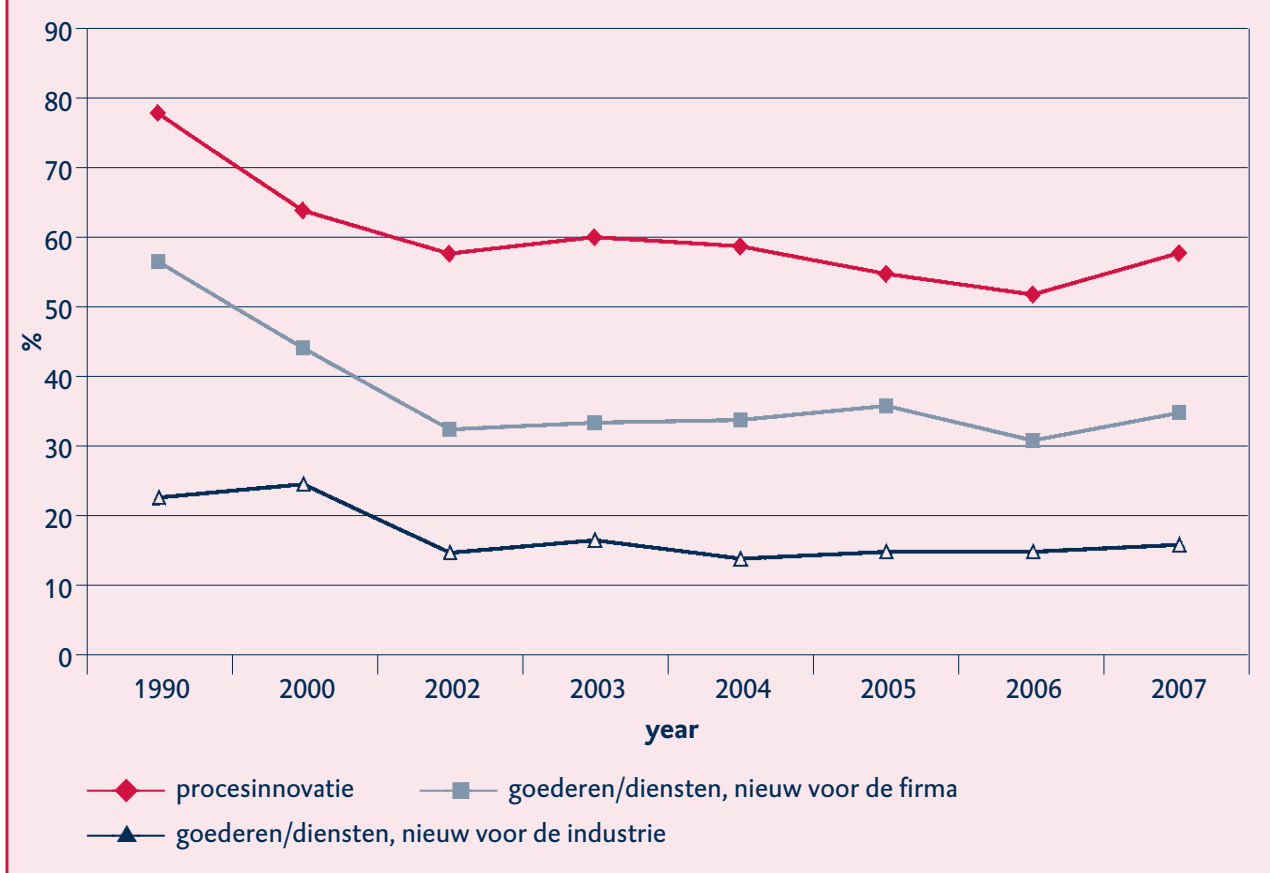

Bron: De Jong en Jansen 2007 
ven is in de afgelopen twee decennia verdrievoudigd. Het betreft hier echter met name zelfstandig ondernemerschap in de zin van self-employment, en dat is verre van gelijk aan het geheel andere begrip van ondernemerschap in de zin van producent van innovatie. De toename van het aantal nieuwe bedrijven is met name toe te schrijven aan het feit dat mensen in loondienst ervoor kozen hun werkzaamheden om fiscale of persoonlijke redenen als zelfstandige zonder personeel (zzp'er) voort te zetten. Gemiddeld genomen is het mkb het laatste decennium eerder minder dan meer innovatief geworden. Dit wordt geïllustreerd in figuur 2.2 met de ontwikkeling van innovatie-outputs van het mkb sinds 1999.

Voorts ligt het percentage innovatieve mkb-bedrijven en het aanbod van early stage venture capital (investeringskapitaal voor de eerste levensfasen van veelbelovende nieuwe bedrijven) ver onder het EU-gemiddelde (zie figuur 2.3).

\section{Figuur 2.3 Innovatie en ondernemerschap in Nederland in relatie tot de EU, 2004}

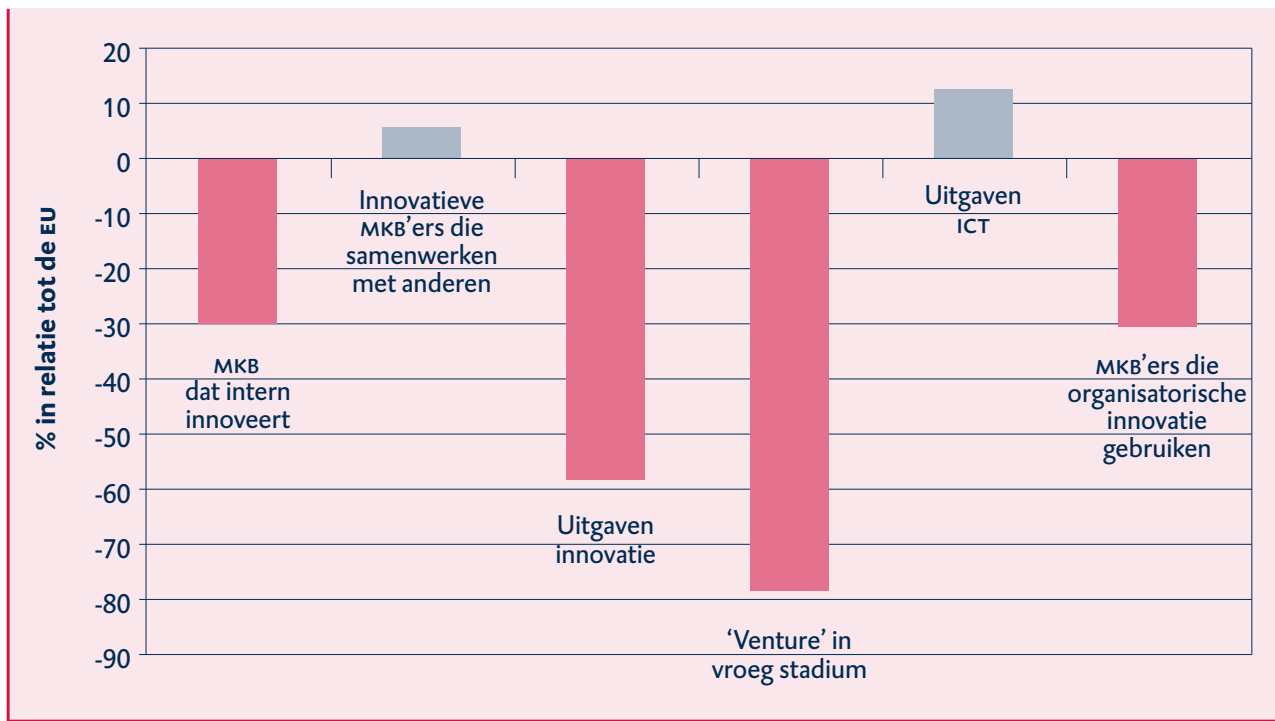

Bron: European Commission 2006

Deze indicatoren laten geen rooskleurig beeld zien van innovatie in Nederland. Dit betekent dat juist nu (een heroverweging van) innovatiebeleid noodzakelijk is.

\subsection{WAAROM INNOVATIE?}

\section{Nut en noodzaak van innovatie}

De uitkomsten van innovatie zijn niet altijd gunstig. Innovatie kan leiden tot onvoorziene negatieve effecten, zelfs onbeheersbare cascade-effecten (bijvoorbeeld in het per ongeluk creëren van een nieuw en niet te bestrijden virus), en leidt vaak tot producten waarvan het maatschappelijke belang niet onmiddellijk evident is (een scheermes met nog een vijfde mesje erbij). 
Het nut van innovatie gaat veel verder dan alleen economisch nut. Innovatie is ook nodig voor het oplossen van maatschappelijke problemen, zoals ten aanzien van energie, milieu, water, medische zorg bij een verouderende bevolking, onderwijs, veiligheid en mobiliteit. Innovatie heeft daarnaast intrinsieke waarde als expressie van creativiteit, in 'the flourishing of people'. Innovatie is bovendien van maatschappelijk belang als basis en prikkel voor ondernemerschap dat paden biedt voor persoonlijk initiatief, integratie en sociale acceptatie.

De economische noodzaak van innovatie komt naar voren in macro-economische analyses van de ontwikkeling van productiviteit (met name de totale factorproductiviteit), die nodig is voor (voortgaande) groei van welvaart. Een belangrijke bron van groei was in de afgelopen decennia de stijging van de arbeidsparticipatie, maar die slaat om in een daling, als gevolg van een verouderende en daardoor minder actieve beroepsbevolking. Innovatie als bron van welvaart wordt daardoor nog belangrijker.

\section{Internationaal perspectief}

Ook de mondiale concurrentie is toegenomen, met zowel kansen als bedreigingen. Kansen om elders producten te (laten) vervaardigen tegen lagere prijzen, kansen in nieuwe buitenlandse afzetgebieden en kansen met bedrijven uit opkomende eco-nomieën die via Nederland hun toegang tot de EU vinden. In dit laatste gooit Nederland hoge ogen als plaats waar stromen van goederen, transacties, mensen en kennis samenkomen en worden gecoördineerd (WRR 2003). De bedreigingen zijn evenwel niet minder groot. Diverse landen (bijv. China, India) lopen in sommige opzichten op Europese landen uit, qua economische groei, qua opleidingsniveaus, R\&D-uitgaven en patenten (Fagerberg 2005). Deze ontwikkelingen hoeven niet gepaard te gaan met een daling van onze welvaart, mits wij maar innovatief genoeg zijn, maar gaan wel gepaard met herstructurering, met plaatselijk verlies en plaatselijk groei van werkgelegenheid. Dat doet een groot beroep op onze inventiviteit en ons innovatie- en aanpassingsvermogen. Innovatie kan zelf creatieve destructie veroorzaken, maar kan ook een uitweg bieden uit dreigende destructie van bestaand werk. Het is juist met het oog op dit aanpassingsvermogen dat de WRR in het rapport Investeren in werkzekerheid (2007) ervoor pleit de kennis en vaardigheden van werknemers voortdurend te actualiseren.

Zoals eerder gezegd, wordt in dit rapport het accent gelegd op micro-/mesoniveau. Ook het gedrag op dat niveau moet echter aansluiten op ontwikkelingen in de wereld. Innovatie moet nadrukkelijk geplaatst worden in de context van de Europese eenwording en mondialisering. Van belang is dan vooral het verschijnsel van de internationale 'versnippering' of 'fragmentatie' van waardeketens (Dicken 2003). Bedrijfstakken liggen nauwelijks meer binnen landen, zeker niet in een klein land als Nederland. Het heeft dan geen zin meer om enig industriebeleid te voeren in de gebruikelijke zin van beleid gericht op ontwikkeling of behoud van bedrijfstakken ('industries') in Nederland. Het gaat eerder om onderdelen van waardeketens die over nationale grenzen heen lopen en die moeten aansluiten op onderdelen elders. Er is voor Nederland bijvoorbeeld waarschijnlijk 
geen perspectief meer voor een geïntegreerde automobielindustrie, maar wellicht wel voor een of andere module van een auto (bijvoorbeeld de 'front end'), in nauwe aansluiting op de automobielindustrie in bijvoorbeeld Duitsland. Dit betekent dat innovatiebeleid zich moet richten op die onderdelen van de keten waar Nederland de meeste toegevoegde waarde kan creëren.

Box 2.3

Opening naar buiten

Een nationaal innovatiebeleid in Nederland moet openstaan voor aansluiting met innovatieve ontwikkelingen in het buitenland. Dat leidt tot een van de vier principes van opening die wij bepleiten: opening naar buiten, vooral voor aansluiting met het buitenland.

Dat vergt niet alleen opening van binnen naar buiten, maar ook van buiten naar binnen: laat buitenlandse bedrijven hier stukken van waardeketens leggen waar Nederland aantrekkelijk in is, en aantrekkelijk gemaakt wordt. Dit lijkt voor de hand te liggen, maar het is allerminst vanzelfsprekend dat in een Nederlands programma voor innovatie ook subsidies of andere faciliteiten verleend worden aan buitenlandse bedrijven die in het buitenland blijven en daar onderdeel vormen van het relevante innovatienetwerk. Aansluiting bij het buitenland kan dan ook gevonden worden door deelname aan programma's van de EU, zoals het Kaderprogramma voor samenwerking in R\&D. Nationale programma's kunnen onder andere gebruikt worden als opstap daartoe.

\subsection{ONTWIKKELING VAN DENKEN EN BELEID}

Dit hoofdstuk laat zien wat het belang van innovatie is. In het denken daarover zijn in de historie diverse stromingen zichtbaar. Deze paragraaf behandelt de voornaamste denkbeelden en ideeën over innovatie en de rol van het overheidsbeleid met betrekking tot innovatie.

Na de Tweede Wereldoorlog, in de jaren veertig en vijftig, waren denken en beleid vooral gericht op wetenschap (w). Achteraf bezien heeft dat alleen te maken met inventie, en dan nog alleen een deel daarvan en niet met innovatie. In de jaren zestig kwam daar belangstelling bij voor toepassing van kennis in technologie en gebruik daarvan in bedrijfstakken en in nieuwe producten en processen, in beleid voor wetenschap en technologie (WT). Dat ging al meer in de richting van innovatie, maar pas in de jaren negentig ontstond een verbreding van de aandacht voor andere dimensies van innovatie, in beleid voor wetenschap, technologie en innovatie (WTI): dit omvatte ook niet-technologische innovatie, marketing, organisatie, ondernemerschap, de diffusie van innovatie en de rol van opleiding daarin (OECD 2007).

\section{Box 2.4 Organisatorische innovaties}

Hoewel pas in de jaren negentig van de vorige eeuw de aandacht voor organisatorische aspecten van innovatie groeide, was het feitelijke belang ervan al veel eerder aanwezig. De eerste industriële revolutie (begin 19de eeuw) had nauwelijks plaats kunnen vinden zonder de organisatorische 
innovaties van een juridische identiteit van een onderneming, beperkte aansprakelijkheid en verhandelbare aandelen, en tenslotte organisatie en toezicht van ver doorgevoerde arbeidsdeling in grootschalige bedrijven. De tweede industriële revolutie (eind 19de, begin 2oste eeuw) hing samen met de instelling van onderzoekslaboratoria in grote industriële bedrijven, vooral in de Duitse chemische industrie. In de derde industriële revolutie, na de Tweede Wereldoorlog, verschoof het leiderschap van West-Europa naar de vs, en in de commercialisatie van micro-elektronica en computer hard- en software speelden daar kleine, nieuwe bedrijven een grote rol, mede als gevolg van een beperkte bescherming van intellectueel eigendom (Bruland en Mowery 2005: 356, 360).

\section{Verbreding van aandacht}

Die verbreding van aandacht hing samen met de onderkenning van innovatie als een niet-lineair proces, met terugkoppelingen van toepassing naar creatie, als verschijnsel dat plaatsvindt in een systeem van velerlei onderdelen en schakels daartussen: kennisinstellingen, bedrijven, toeleveranciers, gebruikers, ontwerpers, tussenpersonen, distributie, ondersteunende diensten, infrastructuur, regelingen en instanties van de overheid en velerlei andere instituties. Er kwam meer aandacht voor de rol van samenwerking en interactie tussen de elementen van het systeem, met daarbij meer aandacht voor ruimtelijke aspecten van locatie en agglomeratie.

In deelvakgebieden groeide de belangstelling voor kennis en leren, onder meer in de economische literatuur en in de sterk in omvang en kwaliteit gegroeide literatuur van management en organisatie. De aandacht voor strategische interactie op microniveau, met gebruik van de speltheorie, nam ook een grote vlucht vooral in de economische literatuur. Er kwam daarnaast meer aandacht voor de sociale aspecten van interactie, zoals sociaal kapitaal en voor effecten van structuren van netwerken en de aard en kracht van verbindingen, in een tak van de sociologische literatuur. Psychologen gingen zich verdiepen in de creativiteit van teams binnen organisaties.

Hiermee is een geweldig potentieel aan inzichten tot stand gekomen. Die kennis blijft echter gefragmenteerd in afzonderlijke stromen van literatuur, in de economie, cognitieve wetenschap, geografie, sociologie, psychologie, sociale psychologie en bedrijfswetenschap. Wetenschappers uit deze disciplines komen er niet toe kennis te nemen van elkaars inzichten, laat staan dat zij die proberen te combineren. Veel wielen worden opnieuw uitgevonden zonder veel acht te slaan op de compatibiliteit van al die wielen. In zijn verkenning heeft de WRR gepoogd enkele wielen tot een voertuig te vormen dat meer beleid kan dragen.

De genoemde verbreding van het innovatiebegrip is ook tot uitdrukking gekomen in de ontwikkeling van empirische indicatoren van innovatie, zoals blijkt uit de meest recente, derde versie van de 'Oslo Manual' (OECD 2005b). Die specificeert plannen voor uitbreiding van het spectrum van indicatoren voor innovatie, waarbij variabelen als marketing, organisatie, ondernemerschap, opleiding en training en diffusie hun intrede doen. Dat gaat zo ver dat in marketingindicatoren ook rekening gehouden wordt met ontwerp en in indicatoren van organisatie ook 
een indicator van kennismanagement wordt opgenomen, evenals indicatoren van externe organisatie in samenwerking tussen bedrijven, tot zelfs het begrip 'sociaal kapitaal'. Daarmee is het einde nog niet in zicht. Men kan pleiten voor verdergaande indicatoren voor organisatie, zoals het vraagstuk van de combinatie van exploitatie en exploratie binnen en tussen organisaties, en organisatorische condities voor creatieve teams en de structuur en sterkte van verbindingen in netwerken en kenmerken van regionale innovatiesystemen. Dan is er nog een vraag naar indicatoren van innovatie bij overheden, en indicatoren van effecten van overheidsbeleid. De vraag is waar het einde ligt van de uitbreiding van indicatoren en hoe hoog de kosten van dit alles zullen zijn.

\section{Additionaliteit van beleid}

Het gaat natuurlijk uiteindelijk om het gebruik van indicatoren voor toetsing en onderbouwing van beleid en ook daar liggen nog problemen (OECD 2007).

Analyse is met name nodig om de 'additionaliteit' van beleid te toetsen: levert het opbrengsten op die zonder dat beleid niet opgetreden waren?

Hoe constateren we additionaliteit? We maken een onderscheid tussen toetsing achteraf van een programma en toetsing vooraf van individuele aanvragen van steun. Toetsing achteraf vergt data over een verloop van tijd, voldoende om effecten te kunnen tonen, en verder data over bedrijven die wel en bedrijven die niet gebruikmaken van het beleid (bijvoorbeeld een subsidieprogramma), maar die voldoende op elkaar lijken om hun prestaties te kunnen vergelijken. Dergelijke analyses komen voor maar zijn nog zeldzaam, omdat de benodigde databestanden en de mogelijkheid van koppeling daartussen vaak niet aanwezig zijn. Het zou bovendien zeer kostbaar worden om dergelijk onderzoek op grote schaal te doen. Niettemin is het raadzaam om beleidsmaatregelen ten minste selectief, naar prioriteit en omvang van de ingezette middelen op deze wijze op additionaliteit te toetsen. Bij de inrichting en uitvoering van het programma moet zo goed mogelijk rekening gehouden worden met het verzamelen van de benodigde gegevens. Bij toetsing vooraf van de additionaliteit van individuele aanvragen kan men vragen om een specificatie van de obstakels die in het geding zijn, van de redenen waarom die niet uit eigen kracht omzeild kunnen worden, de claim te toetsen bij experts of peers die ze kunnen beoordelen. Het is nuttig voor een 'lerende overheid' om die informatie te bewaren als basis voor de beleidsvorming.

\section{Box 2.5 Evaluatie van de innovatievouchers}

Een goed voorbeeld waar de aangegeven procedure is gevolgd, betreft de evaluatie van de innovatievouchers door het СРВ (2007). De mogelijkheid daartoe ontstond doordat er een tekort was aan vouchers, zodat er moest worden geloot. Daardoor kon men achteraf op basis van enquêtering bij deelnemers en niet-deelnemers nagaan wat de verschillen in innovatieve prestatie waren. Van belang was dat zij als redelijk vergelijkbaar konden worden gezien, afgezien van het wel of niet krijgen van een voucher, in die zin dat beide groepen kennelijk belangstelling hadden voor deze weg 
naar innovatie. Daarbij kon men ook de ontwikkeling van effecten in de tijd bezien, van twee golven van vouchers, in 2004 en 2005. De uitkomsten ten aanzien van additionaliteit van de vouchers waren niet eenduidig, maar het gaat hier om de gevolgde methodiek als voorbeeld van hoe het kan en vaker zou moeten.

\section{Het oude denken: focus op RED}

Naast technische problemen valt echter vooral op dat waar de mogelijkheden wel aanwezig zijn, het beleid en het beleidsonderzoek toch blijven hangen in het oude denken in termen van wetenschap en technologie van voor de jaren negentig (Hawkins 2007). De voortdurende focus op R\&D komt in de EU tot uiting in de nadruk daarop in de verklaringen van Lissabon in 2000 en, in vervolg daarop, van Barcelona in 2005 en in de aandacht voor een Europees Instituut voor Technologie (EIT). In Nederland lijkt hij onder andere naar voren te komen in de voortgaande prioriteit voor Technologische Top Instituten. In onderzoeken en rapportages blijkt de voortdurende voorkeur voor R\&D en technologie onder andere uit de indicatoren die we hiervoor hebben gebruikt in figuur 2.1. In de figuren 2.2, 2.3 en 2.4 is daarentegen geprobeerd de aandacht te verbreden naar andere dimensies van innovatie.

Kennelijk is, zoals in andere gebieden, ook in percepties van innovatie in wetenschap, praktijk en beleid de macht van het oude vertrouwde denken groot - in dit geval het denken in termen van wetenschap en technologie - omdat die is ingesleten en vanzelfsprekend en stilzwijgend (tacit) geworden is en daardoor moeilijk vatbaar voor kritiek en verandering. Wat karikaturaal geformuleerd: in het oude denken geldt innovatie $=$ technologie. Omdat de stand van de technologie veelal verbonden is met een bedrijfstak, ontstaat op basis van deze redenering het risico dat innovatiebeleid kenmerken krijgt van industriebeleid.

\section{Het nieuwe denken: focus op het innovatiesysteem}

In het nieuwe denken is innovatiebeleid gericht op het functioneren van het innovatiesysteem, waarbij het gaat om inventie, innovatie en diffusie, door interactie en samenwerking, in ketens en netwerken die grenzen van landen, bedrijfstakken en technologieën overstijgen.

Het ministerie van Economische Zaken besteedt al enkele jaren meer aandacht aan niet-technologische aspecten van innovatie en het denken daarover kan verder ontwikkeld worden. De aandacht voor ondernemerschap is gegroeid en is nog steeds in ontwikkeling. Commercialisatie en aansluiting op productmarkten heeft al redelijk wat aandacht gekregen, maar aandacht voor vraagstukken van organisatie (als onderdeel van 'sociale innovatie') is nog bescheiden. 
Het Nederlandse innovatiebeleid kent een tweetal pijlers: ondersteuning van innovatie in het bedrijfsleven enerzijds en financiering van onderzoek en wetenschap anderzijds. Voor beide pijlers is ongeveer een miljard euro beschikbaar, welke bedragen verschijnen op de begrotingen van de ministeries van EZ en OC\&W.

Naar het inzicht van de raad getuigt het beleid dat zich richt op innovatie en ander beleid dat invloed heeft op innovatie, van de veelzijdige behoeften die het bedrijfsleven in dit opzicht vertoont. Er zijn tal van instrumenten die intensieve toepassing kennen, met name ook ten gunste van kleine bedrijven. We noemen er slechts enkele:

- subsidie voor onderzoek (o.a. WBSO);

- een aanzet tot additionele financiering van R\&D in kleine bedrijven, in navolging van het SBIRprogramma in de vs;

- gesubsidieerde kennisoverdracht naar het mkb (Syntens, het RAAK-initiatief van OCW, innovatievouchers);

- faciliteren van innovatief ondernemerschap (o.a. Technopartner, uitdagerskrediet);

- garanties voor financiering door banken voor kleine bedrijven;

- initiatieven om op het niveau van de EU het gebruik van octrooien goedkoper, sneller en gemakkelijker te maken, vooral voor kleine bedrijven;

- voortdurende pogingen om de complexiteit van regelingen en programma's te reduceren, ook vooral ten behoeve van kleine bedrijven;

- een 'koplopersloket' om innoverende kleine bedrijven langs obstakels in het innovatiesysteem te loodsen.

Er zijn lofwaardige initiatieven ten aanzien van kennis en onderwijs in de 'kennisinvesteringsagenda' van het Innovatieplatform (Innovatieplatform 2006).

Veel van deze instrumenten hebben ten doel om het bedrijfsleven te laten profiteren van de kennis die aan wetenschappelijke en onderzoeksinstellingen wordt ontwikkeld. Dit kenmerk is om meerdere redenen verklaarbaar. Het past bij het langdurig in gebruik zijnde lineaire model waarbij R\&D voorafgaat aan innovatie. Het biedt ook uitvoeringstechnische mogelijkheden, omdat kennisinvesteringen meetbaar zijn. Ook is het een 'veilige' vorm van beleid. Investeren in onderzoek zal, als het al niet baat, toch zeker nooit schaden.

\subsection{CONCLUSIE}

In dit hoofdstuk zijn kort de aard van het innovatieproces en de verschillende daarbij behorende dimensies besproken. Uit een overzicht van de innovatieprestaties van Nederland kunnen we concluderen dat Nederland er op dit gebied niet goed voorstaat en dat juist nu (een heroverweging van) innovatiebeleid nodig lijkt. Hiervoor is een nieuwe kijk op innovatie vereist die meer omvat dan wetenschap en technologie. In de volgende hoofdstukken zal dieper worden ingegaan op de verklaring van innovatieprocessen en de mogelijkheden voor overheidsbeleid ter stimulering hiervan. 
Doel van dit rapport is aan te geven hoe de kwaliteit van het Nederlandse innovatiesysteem kan worden verbeterd. Om dat te kunnen doen, moeten we weten hoe het innovatiesysteem werkt. Met andere woorden: hoe ontstaan innovaties en welke processen spelen daarbij een rol? Dit hoofdstuk gaat in op de bronnen van innovatie. Centraal staan de onvermijdelijke onzekerheid van innovatie - en bijgevolg de onmogelijkheid om innovatief succes te voorspellen en te plannenen de diversiteit van kennis als bron van innovatie. Een evolutionair perspectief, ontleend aan de evolutionaire economie, maakt duidelijk hoe onzekere processen van vormgeving zonder ontwerp vooraf tot stand komen (3.1). Dat dient echter aangevuld te worden met een perspectief van leren en ontdekken als bron van innovatie, met inzichten uit de cognitieve wetenschappen (3.2). Daarmee kan het innovatieproces worden voorgesteld als een cyclisch model (3.3) en als een open proces van samenwerking tussen bedrijven (3.4) waarbij onderling vertrouwen een essentiële voorwaarde is (3.5). De analyse eindigt met een pleidooi voor 'opening in viervoud' (3.6).

\subsection{HET EVOLUTIONAIRE PERSPECTIEF}

\section{Onzekerheid}

Wellicht het meest fundamentele aspect van innovatie is onzekerheid. Dit begrip gaat verder dan de term risico. In tegenstelling tot onzekerheid weet men bij risico welke gebeurtenissen zich mogelijk kunnen voordoen en kan men aan die mogelijkheden kansen toekennen. Dit geldt onder andere voor de verspreiding van redelijk uitgekristalliseerde innovaties waarmee ervaring bestaat in de zin van succes - onder duidelijk herkenbare condities - en falen elders. In die gevallen kan men afwegen en optimaliseren. Onzekerheid ontstaat wanneer men niet alle mogelijke gebeurtenissen kent en men geen kansberekening kan maken. Dat geldt voor toekomstige uitvindingen: die veranderen de mogelijkheden, welke dus vooraf niet bekend en ook niet te voorspellen zijn.

Een algemene evolutionaire theorie, die is afgeleid van biologische evolutie en ook wel wordt aangeduid als het ecologisch perspectief, vormt een vruchtbaar perspectief voor het omgaan met onzekerheid. Immers, in evolutie zit onvoorspelbaarheid 'ingebakken', terwijl desondanks een proces wordt aangegeven waarin nieuwe vormen ontstaan. Die ontstaan zonder voorafgaand doelgericht ontwerp in een cumulatief proces dat padafhankelijk is, in die zin dat het voortbouwt op wat zich eerder ontwikkelde. Volgens het evolutionair perspectief ontstaan nieuwe vormen - in de context hier dus innovaties - uit selectiedruk op een veelheid van min of meer blinde probeersels waarvan het succes niet te voor zien is, gevolgd door een brede verspreiding van wat succesvol blijkt te zijn. 
Net als elders in het beleid bestaat er ook bij innovatie een (diepgewortelde) neiging te denken dat bestuurders weten wat de doelen zijn en daarbij ook de relaties kennen tussen middelen en doelen op basis waarvan zij plannen kunnen maken en directieven kunnen geven voor de uitvoering daarvan. De vraag is echter hoe ze dat kunnen weten onder onzekerheid. Cruciaal voor innovatiebeleid is het stimuleren en handhaven van bronnen van creativiteit en diversiteit, het in stand houden van de selectiemechanismen en de transmissie van succes. En dit alles met onderkenning van het feit dat succes en overleving niet kunnen worden voorspeld en dat mislukkingen erbij horen (WRR 2006a).

\section{Nichecreatie}

De ontwikkeling van nieuwe soorten in de biologie staat model voor innovatie. Volgens de evolutionaire theorie krijgt de ontwikkeling van nieuwe soorten een sterke impuls bij verandering van ecologische niche ('nicheselectie'), als gevolg van externe gebeurtenissen zoals rampen of verandering van klimaat, of doordat migratie tot een nieuwe niche leidt. Naar analogie daarvan argumenteren wij in dit rapport dat innovatie een impuls krijgt van de toepassing van producten, kennis en technologie in nieuwe omgevingen (landen, markten, bedrijfstakken, technologieën, bedrijven) die worden gezocht of opgelegd. In de moderne evolutionaire theorie onderkent men ook het verschijnsel van 'nichecreatie', waar soorten hun selectieomgeving beïnvloeden, in co-evolutie tussen soorten en selectieomgeving. Naar analogie daarvan kan men stellen dat innovaties markten beïnvloeden en dat, doordat markten instituties nodig hebben, zij ook hun eigen instituties creëren, die verdere innovatie in de weg kunnen zitten waardoor men aan die niche moet ontsnappen. In die zin geeft nicheconstructie een prikkel tot selectie van een andere niche. Deze overwegingen vormen een belangrijk deel van het fundament voor ons pleidooi voor opening.

\section{Systeemperspectief}

Het evolutionair perspectief leidt ook tot een systeemperspectief. Daarmee bedoelen we dat innovatie kan worden opgevat als een systeem van velerlei actoren die met elkaar interacteren in het genereren en toepassen van ideeën, waarbij verbindingen tussen de verschillende onderdelen van dat systeem een centrale rol spelen. Deze systeembenadering vormt een deel van het fundament voor ons pleidooi voor aandacht voor andere factoren dan alleen wetenschap en technologie. Het hoofddoel van dit rapport is erop gericht om op basis van de micro-/meso-invalshoek inzicht te verkrijgen in dat ontdekkingsproces en in het evolutionaire systeem (de ecologie van innovatie) en van daaruit aangrijpingspunten te leveren voor overheidsbeleid.

\section{Nuanceringen van het evolutionair perspectief}

Men kan echter ook te ver gaan in de toepassing van de evolutionaire kijk op innovatie. Dat perspectief is nuttig als conceptuele opstap, om los te komen van intuities van innovatie als centraal ontwerp en planning en voor het basisidee 
van variatie, selectie en overdracht als de motor van verandering. De invulling daarvan is echter anders dan in de biologie. In de samenleving komt innovatie voort uit kennis (cognitie) en leren. Leren en innovatie zijn sociaal-culturele processen met eigen kenmerken (Nooteboom 2001). Daarvoor hebben we inzicht nodig in cognitie. In het evolutionair perspectief blijft uitvinding een black box en mede daarom wordt zij in de theorie van innovatie verwaarloosd. Voor een deel komt dit doordat innovatie gedefinieerd is als de succesvolle toepassing en introductie van iets nieuws in de praktijk. Uitvinding wordt gezien, of in elk geval behandeld, als onverklaarbaar. In de biologie is variatie in sterke mate blind en puur toevallig. Ideecreatie daarentegen is weliswaar onvoorspelbaar en in hoge mate ook een kwestie van trial and error - en van toevallige ontdekking - maar is toch ook op een of andere manier gebaseerd op inspiratie uit ervaring, met enige vorm van inferentie. De vraag is hoe dat werkt. Het is van theoretisch belang dat bij innovatie een systematisch verband bestaat tussen de creatie en selectie van variëteit, terwijl de scheiding van creatie en selectie een fundamenteel principe is van de evolutionaire theorie. In de biologie is er reproductieve isolatie tussen soorten, terwijl in de economie nieuwe combinaties gemaakt worden tussen voorheen gescheiden technologieën (bijvoorbeeld tussen informatica en communicatie, in ICT). In de economie kunnen 'uitgestorven’ soorten (zoals oude technologieën) opnieuw tot leven worden gewekt.

\section{Box $3.2 \quad$ Herleving van zeilschepen}

Ten tijde van de oliecrisis in de jaren zeventig van de vorige eeuw, met een verviervoudiging van de olieprijs, werd serieus gedacht aan het opnieuw invoeren van de 'uitgestorven' technologie van zeeschepen met zeilen, maar dan wel van aluminium en computergestuurd.

Doordat de mens gebruikmaakt van communicatie verlopen de verspreiding van het nieuwe en nichecreaties veel sneller dan in biologische evolutie. Dat maakt het probleem dat de gecreëerde niche leidt tot convergentie en consolidatie die verdere vernieuwing in de weg zitten, evenzo urgenter.

Ook anders dan bij evolutie staat in innovatie de creatie van variëteit niet los van transmissie: in de 'overdracht' van kennis, in communicatie, worden betekenissen en ideeën getransformeerd. Overdracht in die zin is eigenlijk veeleer reconstructie.

Dit alles wil overigens niet zeggen dat denken langs evolutionaire lijnen in de economische wetenschap niet toepasbaar zou zijn. Maar bij die wijze van denken in de economie moet rekening gehouden worden met de daar geldende domeinspecifieke omstandigheden.

Een vraag is of er zoiets mogelijk is als een theorie van ontdekking. Een a priori ontkenning van die mogelijkheid berust op een misverstand, ingegeven door de redenering dat het tot ontwikkeling komen van een nieuw idee per definitie onvoorspelbaar is, want als we het konden voorspellen zou het geen nieuw idee 
meer zijn. Men kan echter inzicht hebben in processen van ideegeneratie zonder de pretentie op basis daarvan de uitkomst van dat generatieproces te kunnen voorspellen, net zoals men inzicht heeft in hoe evolutie werkt zonder te kunnen voorspellen welke levensvormen zullen ontstaan. Dat is uiterst relevant voor een beleidsperspectief dat niet uitkomsten wil vastleggen maar wel het proces wil bevorderen dat tot verrassing leidt.

\subsection{KENNIS EN LEREN}

Innovatie vergt leren, op twee manieren. Leren, in de zin van het zich eigen maken van reeds bestaande kennis, is nodig voor de toepassing van ontdekkingen in innovatie en voor de diffusie daarvan. Leren in de zin van de creatie van nieuwe kennis is nodig voor inventie. Dat leren vergt ook afleren, het verlaten van gevestigde ingesleten kennis en praktijken. Gezien de centrale rol van leren in innovatie ligt het voor de hand om gebruik te maken van kennis omtrent kennis en leren uit de cognitiewetenschap, de wetenschap van kennis en leren.

\section{Het belang van verschil}

We maken gebruik van een constructivistisch interactionistisch perspectief volgens welke mensen de wereld zien, interpreteren en beoordelen op basis van mentale categorieën die zich vormen in wisselwerking met andere mensen. Dit interactionistisch perspectief geeft de basis voor een beoordeling van het belang van de verbindingen in het innovatiesysteem in de generatie en diffusie van ideeën. Het constructief perspectief impliceert dat mensen de wereld verschillend zien al naar gelang ze hun cognitie hebben ontwikkeld in verschillende omgevingen, langs verschillende levenspaden. Er is, met andere woorden, een grotere of kleinere 'cognitieve afstand' tussen mensen. Cognitie is hier een breed begrip, dat naast perceptie en kennis ook moraliteit omvat. Dit geeft een nadere onderbouwing van het idee dat in de samenleving kennis divers, verspreid en lokaal ingebed is. In de economische wetenschap is dit benadrukt in de Oostenrijkse school in de economie, met name door Friedrich von Hayek. Een implicatie hiervan is dat een centrale overheid niet in staat is om alle mogelijkheden van de verspreide, lokale, diverse kennis te overzien en dat het verstandig is zich te richten op het aanboren daarvan in een bottom-up-proces van innovatie.

Dit leidt tot een pleidooi om actoren aan de basis van de samenleving, mensen die werken in bedrijven, kennisinstellingen en de overheid, burgers en consumenten, in bedrijven en regio's, ruimte te bieden om te experimenteren met hun eigen oplossingen binnen door de centrale overheid globaal gedefinieerde beleidsterreinen. ICT, en vooral internet, biedt daarvoor geheel nieuwe mogelijkheden met een vooralsnog onbekende reikwijdte.

\section{Relatie tussen theorie en praktijk}

Het web van mentale categorieën van een individu vormt diens 'absorptiecapaciteit': het vermogen tot het vormen van percepties, interpretaties, inzicht en oordelen. Dat vermogen impliceert een beperking: men kan slechts absorberen 
wat inpasbaar is. Maar bij absorptie is ook in zekere mate sprake van reconstructie, zowel van wat geabsorbeerd wordt als van het cognitieve apparaat waarin de absorptie plaatsvindt. Die transformerende absorptie noemen we assimilatie. Zelfs herinnering is geen kwestie van het ophalen van wat opgeslagen is, maar reconstructie, die beïnvloed wordt door de context en de triggers van herinnering. 'Kennisoverdracht' draagt in dit licht een misleidende connotatie. Zij is geen overdracht van iets dat blijft wat het is, maar is een reconstructie daarvan. Goederen worden getransporteerd, kennis wordt getransformeerd. Zoals eerder is aangegeven, komt dit erop neer dat in termen van evolutionaire theorie transmissie tevens een bron van variatie is. Met andere woorden, leren in de zin van bestaande kennis verkrijgen is - tot op zekere hoogte - een kwestie van nieuwe kennis construeren. Dit maakt ook dat het onderscheid tussen innovatie en diffusie enigszins vervaagt. Als iemand een innovatie adopteert, zal dat gepaard gaan met veranderingen om de innovatie in te passen en aan te vullen met wat men al weet, kan en daarbij nog extra creëert.

Een beleidsimplicatie van deze gedachtegang is dat relaties tussen theorie en praktijk en daarmee tussen universiteit en bedrijfsleven, niet alleen een kwestie zijn van toepassing van wetenschappelijk onderzoek, maar ook van inspiratiemede - vanuit de praktijk. Een centrale vraag, onder andere voor wetenschapsbeleid, is hoe de interactie tussen generatie (exploratie) en gebruik (exploitatie) van ideeën plaatsvindt.

Exploitatie betekent de toepassing en verbetering van nieuwe ideeën, principes, concepten, of logica, terwijl exploratie het proces is waarin deze ontstaan. Aan de ene kant vullen deze twee processen elkaar aan en brengen zij elkaar voort, maar aan de andere kant stellen zij ook verschillende eisen: een verschillende mentaliteit, benadering, wijze van bestuur en organisatie waardoor zij moeilijk tegelijkertijd en op dezelfde plaats te combineren zijn. Wij zien dit probleem overal: in bedrijven bij het spanningsveld tussen R\&D enerzijds en operationele en productieactiviteiten anderzijds, bij het spanningsveld tussen ondernemerschap en bedrijfsvoering, bij het spanningsveld tussen universiteiten (exploratie) en bedrijfsleven (exploitatie) en bij het spanningsveld tussen de ontwikkeling en de uitvoering van beleid.

\section{$3 \cdot 3$ ONTDEKKING EN TOEPASSING}

\section{Cyclisch innovatiemodel}

In deze paragraaf gebruiken we een 'cyclisch innovatiemodel' van wisselwerking tussen inventie, innovatie en diffusie, dat het oude 'lineaire model' van de overdracht van kennis uit onderzoek in het denken over innovatie heeft vervangen. Volgens het cyclisch model kunnen we het innovatieproces zien als een spiraal van inventie (uitvinding, ideegeneratie), ontwikkeling, commercialisatie, marktpenetratie en diffusie, consolidatie, en differentiatie, die weer leidt tot het begin van inventie. Dit geeft aan hoe exploitatie en exploratie elkaar opvolgen, en uit elkaar voortkomen (zie figuur 3.1). 
Figuur 3.1 Cyclus van innovatie

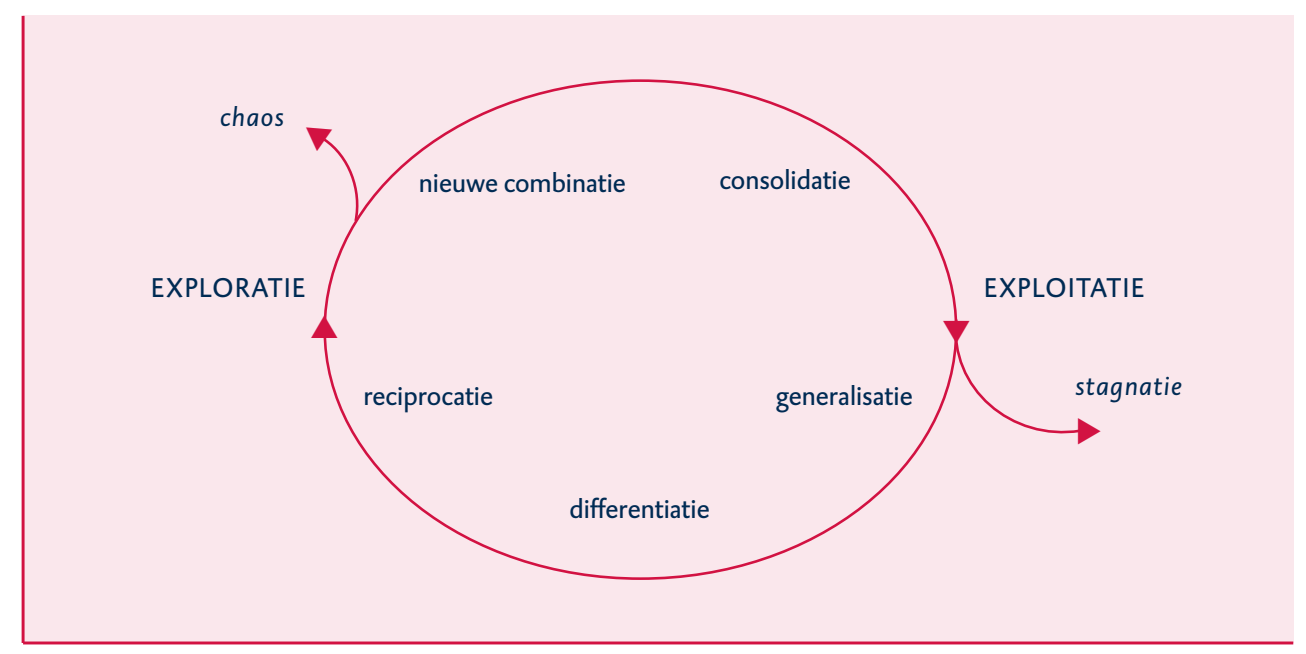

De achtergrond hiervan is de toepassing van bestaande kennis en competenties in nieuwe contexten (bijvoorbeeld nieuwe toepassingen van wetenschap en technologie, nieuwe markten van producten, een nieuwe werkkring voor mensen). Dit wordt generalisatie genoemd. Die leidt tot een confrontatie met nieuwe eisen van overleving die tot aanpassing kunnen nopen (Nooteboom 200o). Dit is analoog aan het principe van nicheselectie in de evolutionaire theorie, volgens welke een nieuwe ecologische niche de ontwikkeling van nieuwe soorten bevordert. Dit vergt 'opening naar buiten', in het opzoeken van nieuwe uitdagingen en 'opening van buiten naar binnen', in het toelaten van nieuwe uitdagingen. Om daarbij exploitatie zo veel mogelijk in stand te houden kan men differentiatie toepassen. Dat wil zeggen dat geprobeerd wordt tot aanpassing te komen door nieuwe selecties te zoeken uit een bestaand repertoire, dat in eerdere ervaring is opgebouwd.

\section{Box $3.3 \quad$ Senseo}

Het Senseo koffieapparaat, ontwikkeld in een alliantie tussen Philips en Douwe Egberts, is een mooi voorbeeld van een schumpeteriaanse 'nieuwe combinatie'. Hoe ontwikkelt het zich verder? Het is onlangs gedifferentieerd met de invoering van een fel rood model, om te appelleren aan emoties van nieuwe klanten in de Braziliaanse markt, dat elders niet verkocht wordt. Het product is ook gedifferentieerd met pads voor thee in plaats van koffie.

Als differentiatie niet volstaat voor overleving in de nieuwe omgeving kan men zich laten inspireren door praktijken in de nieuwe omgeving die daar lijken te functioneren waar eigen praktijken falen. Men kan dan experimenten aangaan met nieuwe combinaties van bekende elementen uit bestaande praktijken en nieuwe elementen uit onbekende praktijken die men tegenkomt ('reciprocatie' genoemd). Dit leidt tot zogeheten 'hybride' praktijken, die als voorlopers de tran- 
sitie naar radicale vernieuwing inluiden (Mokyr 1990). Kenmerkend voor hybriden is dat men het potentieel van nieuwe elementen kan verkennen zonder reeds de basislogica, structuur of architectuur van de bestaande praktijk prijs te geven. Het nadeel van hybriden is dat ze leiden tot inefficiënties in het systeem ('spaghetti'), overlap en doublures, misfits en workarounds om die op te lossen. Dat geeft aanzetten tot meer radicale, architecturale verandering (Henderson en Clark 1990). De periode met de hybride geeft inzicht in welke elementen men het liefst zou willen behouden, gezien hun prestaties en de richtingen waarin men zou kunnen denken voor nieuwe principes van ontwerp of architectuur waarmee nieuwe elementen beter hun potentieel kunnen realiseren. Dit vergt 'opening voor verassingen'. In dit stadium kunnen kleine veranderingen in ontwerpprincipes leiden tot sprongsgewijze verandering in de functies van het geheel.

\section{Box $3.4 \quad$ Stoomschepen}

Een klassiek voorbeeld van een hybride is het stoomschip. De eerste stoomschepen waren niet meer dan zeilschepen met een stoommachine er op als hulp bij ongunstige wind of stromingen. De Savannah, het eerste stoomschip dat in 1819 de Atlantische Oceaan overstak, gebruikte de stoommachine voor 80 uur tijdens een reis van 30 dagen. Pas 14 jaar later werd voornamelijk op stoom gevaren. Verdere uitvindingen en verbeteringen waren nodig, zoals de schroef als vervanging van het raderwiel. Zeewater deponeerde zout in de boiler en dat veroorzaakte explosies. Dat vergde een scheiding tussen het water dat de condensator koelde en het water in die condensator. Houten schepen waren te klein voor grote machines en voor efficiënt gebruik. Dat vergde een overgang naar stalen schepen en dat gebeurde in de tweede helft van de negentiende eeuw (Mokyr 1990: 128).

Uit de beschrijving van het ontwikkelingsproces volgens het cyclische innovatiemodel blijkt dat inventie onderhevig blijft aan trial and error zonder geheel blind te zijn, omdat zij geworteld is in een proces van toepassing en aanpassing op basis van opmerkzaamheid, verbeelding en onder druk van overleving. Zij geeft ook aan hoe exploratie voort kan komen uit exploitatie. Zij geeft aan hoe een ogenschijnlijk sprongsgewijze vernieuwing kan ontstaan uit een meer geleidelijk proces van stappen op weg daar naartoe. Cruciaal in het proces is opening naar nieuwe contexten met nieuwe uitdagingen en mogelijkheden, opening voor samenwerking voor het verkennen van nieuwe combinaties, opening in de vorm van nieuwsgierigheid en aandacht voor vreemde praktijken, en de bereidwilligheid experimenten met elementen daarvan aan te gaan en de bereidheid te experimenteren met verrassende hybriden.

Exploratie kan stranden in een chaos van prototypes en pogingen die maar niet door willen breken omdat zij technisch of commercieel niet levensvatbaar zijn, of van een strijd waar maar geen winnaar uit kan komen. Als een doorbraak slaagt, loopt zij vervolgens bij pogingen om oude praktijken te vervangen op tegen het obstakel dat bestaande instituties en markten die daar de selectieomgeving vormen de introductie tegenhouden. Het is dan vaak zo dat radicale innova- 
ties pas veel later breed doorbreken en tijdelijk alleen daar worden doorgevoerd waar hun bestaan in te passen valt in de bestaande orde. Het is een bekend verschijnsel dat aanvankelijk innovaties daar ingang vinden waar hun toepassing het makkelijkst te verwezenlijken is en in een latere fase daar waar ook het potentieel het best benut kan worden (zie tekstbox 3.5). Vooral hier is het van belang om opening te verschaffen voor buitenstaanders die met hun innovaties toegang zoeken tot de markt.

\section{Box 3.5 Stoommachines}

Stoommachines werden eerst gebruikt voor het leegpompen van tin- en kolenmijnen, voordat zij gebruikt werden voor transport, waar bestaande technologieën vervangen moesten worden, zoals de paardentram en zeilschepen. Voor die overgang waren ook verdere technologische ontwikkelingen nodig om de machine kleiner en efficiënter te maken. Een doorbraak daarbij was de uitvinding van Watt voor de scheiding tussen zuiger (heet) en condensator (koud) (Mokyr 1990: 85).

Het proces van ontdekking vergt opening ten aanzien van de uitkomst ervan. Men kan beginnen met een intuïtie van waar men naartoe denkt te gaan, maar men komt meestal ergens anders uit. Het beroemde scheerapparaat Philishave van Philips begon als ontwikkeling van een nieuwe dynamo voor fietsverlichting. Innovatie vergt dat men een open mind heeft voor wat eruit mag komen. Dat vergt dat men niet succes en beloning afstemt op wat vooraf verwacht wordt. Dat vergt nieuwe vormen van subsidiëring, financiering, verantwoording en afrekening.

In het begin van een doorbraak is er veelal concurrentie tussen verschillende vormen en prototypen van het nieuwe. Naast technische levensvatbaarheid ontstaat de vraag naar commerciële levensvatbaarheid, waarbij de aandacht verschuift van technologie naar commercie en van vorm naar prijs. Na verloop van tijd leidt selectie in laboratorium en markt tot convergentie op een 'dominant ontwerp'. De overgang in de ICT van 'mainframes' naar pc's is hiervan het schoolvoorbeeld. Daardoor vermindert de onzekerheid voor gebruikers, neemt de vraag toe, treden nieuwe aanbieders toe om van de opkomende markt te profiteren en neemt de prijsconcurrentie toe. Prijzen komen onder druk, wat weer nieuwe gebruikers uitlokt. Winstmarges nemen af, tenzij barrières voor concurrentie opgeworpen worden. Daardoor verschuift de concurrentie van vorm naar kosten, met gebruik van efficiëntie van grotere schaal waar aanwezig, mogelijk gemaakt door toenemende vraag. De aandacht verschuift naar de organisatie van productie en distributie, voor maximale efficiëntie. De structuur van markt, infrastructuur en instituties vormt zich naar de optimalisatie van exploitatie. Dit is analoog aan het principe van nichecreatie in de evolutionaire theorie. De arbeidsmarkt en leveranciers specialiseren zich op de nieuwe competenties en behoeften (Boschma en Lambooy 1999). Deze vormen van specialisatie oefenen aantrekkingskracht uit op nieuwe deelnemers aan het zich ontwikkelende veld. Er ontstaan netwerken met centrale actoren die het netwerk stabiliseren. Stan- 
daardisatie van praktijken en organisatie bepaalt percepties van waaraan men moet voldoen. Al deze ontwikkelingen leiden tot stabilisatie en consolidatie. Vervolgens dreigt het gevaar van stagnatie, in verstening van het succes. Voor een nieuwe ronde van exploratie moet men daaraan ontsnappen door uit te wijken naar nieuwe niches en nieuwe toepassingen. En als we dat doen, betreden we weer het pad van exploratie, zoals besproken.

Aldus ontstaat een 'cyclus van innovatie', met een bovenlus waar exploitatie ontstaat uit exploratie, en een onderlus waar exploratie ontstaat uit een verschuivende exploitatie, zoals geillustreerd in figuur 3.1. De bovenliggende lus, van exploratie naar exploitatie, is bekend terrein in de innovatieliteratuur. De onderste lus, van exploitatie naar exploratie, is nieuwer. Exploitatie kan doodlopen in stagnatie. Dan wordt het hard nodig om dingen weer af te leren, in nieuwe uitdagingen van generalisatie. Die kan men vrijwillig zoeken in nieuwe omgevingen of zij kunnen van buitenaf worden aangeboden of opgedrongen. In termen van evolutionaire theorie: de bovenste lus is er een van niche construction en de onderste komt voort uit niche selection. Empirische evidentie voor de cyclus wordt door Gilsing (2005) gegeven in een analyse van de overgang van exploratie naar exploitatie in de ontwikkeling van nieuwe media in Nederland en een analyse van de koppeling in de Nederlandse biotechnologie tussen exploratie in kleine biotechnologiebedrijven en exploitatie in grote farmaceutische bedrijven. De hierboven gegeven conceptualisering van het proces van innovatie heeft velerlei implicaties, voor zowel de grote lijn van de analyse als voor details.

\section{Convergentie en sluiting}

Op het pad van exploratie naar exploitatie treden convergentie en sluiting op. Convergentie is de ontwikkeling en vaststelling van een dominant ontwerp; sluiting is de ontwikkeling van standaarden voor technologie en organisatie. Het ontstaan van convergentie kan in belangrijke mate worden overgelaten aan de marktwerking, terwille van efficiënte allocatie ter optimalisatie van de exploitatie. Dat vergt natuurlijk wel de gebruikelijke instituties van eigendom, transactie, contract, mededingingsbeleid en dergelijke. Er is sluiting in de zin van stabilisatie van technologie en marktstructuur. Dit mag niet gepaard gaan met het dicht timmeren van de markt. Er dienen openingen in de markt te zijn voor levendige concurrentie op kosten en incrementele verbeteringen. Verzadiging van een markt geeft een prikkel voor productdifferentiatie en nieuwe toepassingen en deze opening kan leiden tot nieuwe exploratie. In die exploratie is de effectiviteit van marktwerking minder vanzelfsprekend, omdat de inmiddels ontstane marktstructuren, belangen en instituties zich tegen opening zullen verzetten. Met andere woorden, markten creëren hun eigen instituties die efficiënte allocatie mogelijk maken maar ook obstakels vormen voor ontsnapping aan gevestigde structuren, normen en praktijken. 
Mobiele telefonie vergde een nieuwe technologie en infrastructuur van communicatie, via kabel en satelliet, locatie en identificatie van de cell phone in een geografisch rooster van cellen, de keuze van technische standaards en verdeling van frequenties. Men kan wellicht ook zeggen dat het een opheffen van telefoonmonopolies vergde, alsmede privatisering.

\section{Internationalisering}

De analyse heeft ook implicaties voor de rol van internationalisering. Internationalisering is een vorm van opening naar nieuwe contexten, en kan de basis vormt van het proces waarin het bestaande wordt geconfronteerd met nieuwe uitdagingen en inzichten die leiden tot nieuwe ideeën. Waar grote bedrijven vroeger internationaliseerden voor groei van omzet en voor een uitweg uit verzadigde markten, gebruiken zij nu in toenemende mate internationalisering als een proces van ontdekking en innovatie (Bartlett en Goshal 1989). Dat is ook een van de redenen waarom grote bedrijven ook hun R\&D voor een deel in andere landen plaatsen, om van het innovatieve potentieel aldaar te profiteren (Cantwell en Piscitello 1999). Het gaat daarbij dus niet alleen om lagere kosten.

\section{Mobiliteit van arbeid}

Er zijn ook implicaties voor de mobiliteit van arbeid, waardoor toepassing van kennis en competentie in nieuwe contexten het pad tot ontdekking kan openen. Datzelfde geldt voor spin-offs vanuit bedrijven van medewerkers die zelfstandig hun ideeën gaan ontwikkelen in een andere omgeving, vrij van de gebaande paden van het bedrijf. De analyse geeft ook aan waarom interdisciplinariteit een bron van innovatie kan zijn, doordat principes van de ene discipline worden onderworpen aan nieuwe uitdagingen en indicaties voor vruchtbare combinaties van principes uit de andere discipline. Met andere woorden: de cyclus geeft een nadere analyse van innovatie als het maken van nieuwe combinaties, zoals voorgesteld door Schumpeter.

\section{Box 3.7 Opening voor innovatie}

Eerder beweerden wij dat het beleid de onvoorspelbaarheid van innovatie moet accepteren en de ondersteuning vooral moet zoeken in het faciliteren van processen die verrassingen opleveren. Op grond van de huidige analyse zou dat het volgende kunnen betekenen.

- Het stimuleren van 'generalisatie', dat wil zeggen de migratie van bestaande competenties naar nieuwe terreinen van mogelijke toepassing, zowel extern, van Nederland naar buiten, als intern, binnen Nederland. In dit opzicht is de liberalisatie van handel van grote betekenis voor innovatie. Het principe geldt ook voor migratie van werkers naar nieuwe werkomgevingen, in binnenen buitenland. Het geldt bijvoorbeeld ook voor migratie en contact tussen universiteiten en bedrijfsleven. Hier ligt het belang van opening naar buiten.

- Het stimuleren van 'reciprocatie', dat wil zeggen experimenten met nieuwe combinaties van elementen uit verschillende praktijken, met acceptatie van de onvermijdelijke problemen van 
resulterende hybriden. Dit vergt een zekere ruimte voor experimenten met een zekere afscherming van al te vroege selectie door concurrentie. Hier ligt het belang van opening voor samenwerking en van opening voor verrassing voor nieuwe dingen die niet passen in bestaande verwachtingen, doelen en systemen.

- Aandacht voor toetredingsbarrières voor innovatieve doorbraken in een selectieomgeving die verandering behoeft om de innovatie toe te laten. Hier ligt het belang van opening voor buitenstaanders.

De combinatie van exploitatie en exploratie binnen organisaties is niet eenvoudig en vormt een centrale uitdaging voor het bestuur. Dit wordt nader beschouwd in hoofdstuk 7. Een dilemma doet zich met name voor in de relatie tussen beheersing en flexibiliteit. Beheersing, op basis van duidelijke normen en een stabiele taakverdeling is nodig voor efficiëntie ('exploitatie') en voor verantwoording. Het proces van ontdekking ('exploratie') vergt echter flexibiliteit, met ruimte voor afwijking van bestaande normen.

\subsection{OPEN INNOVATIE}

Innovatie bestaat vaak uit schumpeteriaanse 'nieuwe combinaties', en dat geeft aan dat een belangrijke bron van innovatie ligt in samenwerking tussen mensen of bedrijven met verschillende kennis, competenties en middelen om samen tot die nieuwe combinaties te komen. In de afgelopen jaren heeft het idee van 'open innovatie', na ontwikkeld te zijn in de innovatiewetenschap ook in de praktijk terrein gewonnen (Chesbrough 2006). Daar wordt mee bedoeld dat bedrijven niet in isolement moeten proberen te innoveren, maar in samenwerking met anderen. Dat geeft efficiënties van schaal en scope en vooral van belang voor innovatie, een grotere diversiteit en flexibiliteit voor de nieuwe combinaties. De diepere achtergrond, zo stellen wij voor, ligt in de voordelen van cognitieve afstand.

Cognitieve afstand geeft een probleem en een kans. Cognitie heeft hier, zoals eerder al vermeld, betrekking op zowel rationele als morele dimensies van cognitie, op kennis en oordeel. Het probleem is dat men moeilijker samenwerkt naarmate de afstand groter is, omdat men elkaar slechter verstaat (minder passende absorptiecapaciteit) en verschillende opvattingen heeft over samenwerking. De kans ligt hierin dat juist het verschil een mogelijkheid biedt om iets te leren. Innovatie wordt bevorderd door een balans tussen verschil en overeenstemming, in optimale cognitieve afstand: groot genoeg om elkaar iets nieuws te vertellen, maar niet zo groot dat men elkaar niet kan verstaan (Nooteboom 1999). Hier zien we het belang van diversiteit maar ook van beperking ervan.

Dit wordt geïllustreerd in figuur 3.2. De dalende rechte lijn geeft weer dat het moeilijker is om samen te werken en elkaar te begrijpen, naarmate de cognitieve afstand toeneemt. De stijgende rechte lijn geeft weer dat de nieuwheidswaarde van de relatie dan toeneemt. Als de innovatieve prestatie gelijk is aan het wiskun- 
Figuur 3.2 Optimale cognitieve afstand

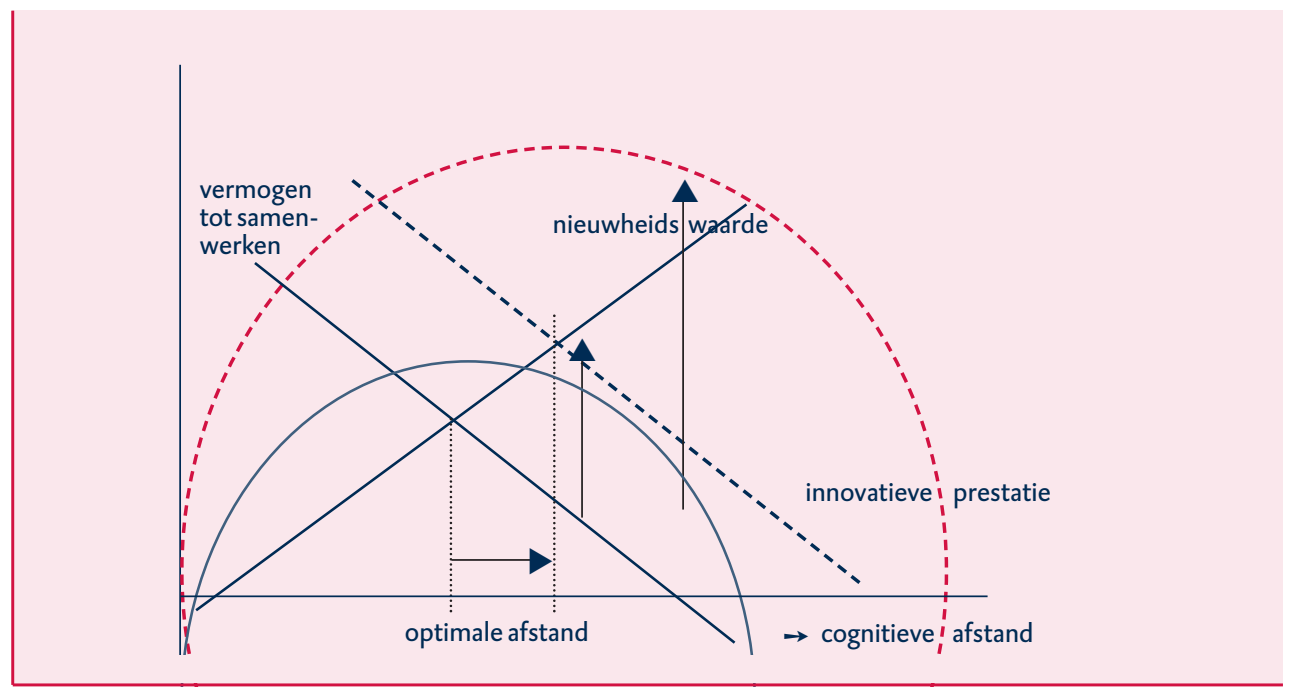

dig product van nieuwheidswaarde en het vermogen die te realiseren in samenwerking, dan ontstaat een omgekeerde $U$-vormige relatie, met een optimale cognitieve afstand.

\section{Box 3.8}

\section{Empirische evidentie}

Een econometrische bevestiging van het model van de optimale cognitieve afstand is gegeven door Nooteboom et al. (2007), in een analyse van 994 allianties van 116 bedrijven in een periode van 10 jaar. Als maat voor innovatieve output werden octrooien genomen, en als proxy voor cognitieve afstand het verschil tussen technologische profielen geconstrueerd op basis van octrooigegevens. Li et al. (2007) vonden een bevestiging in een analyse van samenwerking tussen toeleveranciers en producenten van 1635 innovaties van 55 o Canadese bedrijven in 35 jaar. Innovatieve prestatie werd gemeten als aantal radicale innovaties (nieuw voor de wereld) en cognitieve afstand werd gemeten als verschil in positie in de classificatie van bedrijfstakken.

Bij al te grote cognitieve afstand kan de parabool onder de nul-as duiken en wordt de prestatie negatief.

\section{Waarom samenwerking?}

Het wordt algemeen erkend dat voor innovatie samenwerking nodig is, maar waarom eigenlijk? Het is evident dat samenwerking meer variatie en flexibiliteit geeft voor nieuwe combinaties dan integratie van activiteiten in een enkele organisatie, maar waarom is het ook cognitief vruchtbaar? Het eerder beschreven proces van innovatie geeft een antwoord op deze vraag. Interactie dwingt de deelnemers om hun ideeën in te passen en aan te passen in het denkkader van de ander (generalisatie). Verschillen worden duidelijk en geven aanleiding tot andere 
selecties uit bestaande kennis (differentiatie). Indicaties doen zich voor van mogelijkheden om onderling elementen van elkaars denken in te passen in nieuwe hybriden van denken en doen (reciprocatie), die prikkels en indicaties geven tot een nieuwe integratie van gezamenlijk denken en doen. Door inventief gebruik van metaforen en voorbeelden kan men elkaar helpen de cognitieve afstand te overbruggen en wederzijdse inpassing en aanpassing van ideeën te bevorderen.

Organisaties hebben belang bij goede samenwerking. Daarom proberen zij de interne cognitieve afstand in te perken in een zekere 'cognitieve focus'. Maar er moet voldoende afstand overblijven voor interne innovatie. Die focus geeft per definitie een vorm van bijziendheid (group think), die gecompenseerd moet worden in externe contacten met actoren (personen, bedrijven) met een andere, complementaire cognitieve focus 'externe economie van cognitieve scope' (Nooteboom 1992). Aldus ontstaat het beeld van figuur 3.2 opnieuw, maar nu op het niveau van organisaties, waar cognitieve afstand betrekking heeft op het verschil in 'cognitieve focus' van de organisaties.

Het vermogen samen te werken met andersdenkenden ligt niet vast. Zij groeit met de accumulatie van kennis en ervaring in die samenwerking. Dit wordt in figuur 3.2 geillustreerd door de stippellijnen. Als de dalende lijn, die het vermogen tot samenwerken voorstelt, omhoog schuift, dan schuift de optimale cognitieve afstand naar rechts en neemt ook de bijbehorende innovatieve prestatie toe (Nooteboom et al. 2007). Voor bedrijven geeft het aldus een concurrentievoordeel om ervaring op te bouwen in samenwerking met andersdenkenden: men kan samenwerken op grotere cognitieve afstand en daardoor komen tot meer radicale innovatie. ${ }^{1}$

Als bedrijven langdurige relaties onderhouden en die relaties ook exclusief zijn, dat wil zeggen afgesloten zijn van andere contacten buiten de groep, dan zal na verloop van tijd de cognitieve afstand afnemen. Op den duur zal de cognitieve afstand zo zijn afgenomen dat het innovatieve potentieel van de relaties verdwijnt (Wuyts et al. 2005). Dan kan het nodig zijn om te zorgen voor voortdurende verversing van de groep, met toetreding van outsiders en uittreding van insiders. Langdurige relaties hebben echter niet noodzakelijk dit effect. Als partijen ook externe relaties onderhouden, buiten de groep, waardoor zij voortdurend gevoed worden met nieuwe ideeën en impulsen van buiten kan ook een langdurige relatie innovatief blijven.

Kortom, open innovatie vergt niet alleen dat men met anderen samenwerkt maar ook dat men opening blijft betrachten voor de toetreding van buitenstaanders, of ervoor zorgt dat er opening is in de vorm van relaties met andere groepen. Men moet zorgen voor opening in drie betekenissen: samenwerking met anderen, opening van toetreding door buitenstaanders en opening voor relaties buiten de groep. 
De notie van optimale cognitieve afstand heeft ook implicaties voor nadere invulling van het eerder besproken innovatieproces, met name de stap van generalisatie. Het is aan te raden een nieuwe context van toepassing te zoeken, bijvoorbeeld een land voor export van een product, op optimale cognitieve afstand.

De analyse heeft ook politieke implicaties voor het nut van enerzijds diversiteit en anderzijds gedeelde percepties binnen landen en binnen Europa. Diversiteit binnen landen en Europese diversiteit bieden een bron van innovatie (Crescenzi et al. 2007) en een zekere mate van gedeelde percepties en waarden geeft een kans om daarvan te profiteren.

\subsection{VERTROUWEN}

Voor samenwerking in innovatie is vertrouwen van groot belang. Samenwerken is echter moeilijk en loopt vaak fout. Bij het opzetten van samenwerkingsrelaties is er vaak weinig aandacht voor problemen van machtsvorming, reputatie, status, wantrouwen en gebrek aan begrip. Het wordt vaak als gemakkelijker gezien wanneer men 'de baas' is en kan vertellen 'hoe het moet', dan wanneer men moet samenwerken zonder overkoepelende hiërarchie en men een evenwicht moet zoeken van wederzijds belang, zonder dat er een hogere 'baas' is die conflicten oplost. De verleiding bestaat dan om de overheid in die rol van de baas te zetten. De uitdaging is om dat niet te doen en de kunst van samenwerking te leren. Dat vergt vertrouwen, maar elkaar vertrouwen is moeilijk.

Vertrouwen is bij uitstek bij innovatietrajecten van belang, omdat het de sleutel vormt tot vruchtbare samenwerking. Immers, bij innovatie is het sturen van relaties door middel van contracten en materiële prikkels problematisch als gevolg van de onzekerheid die gepaard gaat met innovatie en het nieuwe van de kennis en competentie, waardoor de mogelijkheden tot contractueel vastleggen, waarnemen en evalueren van competenties en prestaties ('monitoring') beperkt zijn. En waar sturing op contract, hiërarchie en monitoring minder mogelijk is heeft men meer vertrouwen nodig. Dit geldt vooral in de vroege innovatiestadia (exploratie), waarin niemand weet wat de doelen en middelen en de verbanden zijn en welke competenties nodig zijn. In verschillende iteraties moet men op zoek naar evenwicht van belang en inzicht in doelen, middelen en de causale relaties daartussen. Dit is kwetsbaar voor de druk van concurrentie, die de nodige speling in tijd en middelen kan elimineren.

'Vertrouwen' is echter een rijk en glibberig begrip dat veel misverstanden oproept. Is vertrouwen een kwestie van beheersing op basis van dwang of prikkels, of een kwestie van moraliteit, of van emotie, of een combinatie van dit alles? Men hoort vaak dat vertrouwen transparantie vergt, maar is opgelegde transparantie niet een bewijs van wantrouwen? Hier is geen plaats om recht te doen aan de complexiteit van het begrip en het gebruik van vertrouwen, in de mogelijkheden en de beperkingen ervan (Nooteboom 2002). We stippen slechts enkele elementen aan. 


\begin{abstract}
Vertrouwen heeft last van 'causale ambiguïteit'. Als er iets fout gaat kan dat liggen aan een ongeluk, beperkte competentie, gebrek aan aandacht, soms zelfs boze opzet uit opportunisme. De kunst is om niet meteen het ergste - opportunisme te vrezen, en boos weg te lopen (exit). Van cruciaal belang is open communicatie (voice) van beide kanten in de relatie. Als (potentieel) slachtoffer moet men zijn zorg uiten om er achter te komen wat de oorzaak van (mogelijk) falen is en wat er aan gedaan kan worden. Als veroorzaker moet men zwakheden en fouten niet verhullen maar tijdig melden, zodat men er zo snel mogelijk samen iets aan kan doen. Maar die vrijwillige transparantie van de partner moet wel worden verdiend, door er constructief op te reageren: bij een gemeld probleem niet meteen blaam en straf, maar gezamenlijke inzet voor verbetering.
\end{abstract}

Derden, of tussenpersonen, kunnen een belangrijke rol spelen bij de besturing van samenwerking. Voor de oplossing van geschillen kan gebruikgemaakt worden van arbitrage of bemiddeling, maar de rollen van een tussenpersoon gaan verder dan dat. Er is één aspect dat daarbij bijzondere aandacht verdient. Zoals zojuist vermeld heeft vertrouwen te lijden onder 'causale ambiguïteit': als er iets misgaat is vaak niet duidelijk wat er is misgegaan en waarom. Je kunt de verkeerde conclusie trekken dat de oorzaak opportunisme was, omdat je daar het bangst voor bent, terwijl het in feite slechts een ongelukje was. Een tussenpersoon kan helpen duidelijkheid te verschaffen over wat er echt aan de hand is. Regelmatige evaluatie van de ontwikkeling van de relatie door een tussenpersoon kan misverstanden voorkomen die leiden tot een vicieuze cirkel van wantrouwen, bij escalatie waarvan geen herstel meer mogelijk is. Verder kan een tussenpersoon bijdragen aan een betrouwbaar reputatiemechanisme door beschuldigingen van opportunisme of incompetentie te onderzoeken (filtering) en alle partijen op de hoogte te stellen van de resultaten daarvan (broadcasting).

\title{
Box $3.9 \quad$ Bemiddeling door zakelijk dienstverleners
}

\begin{abstract}
Als het verhaal over open innovatie hout snijdt, dan opent zich een markt voor nieuwe zakelijke dienstverlening in de vorm van dergelijke bemiddeling. Tot op zekere hoogte wordt die rol al gespeeld door bijvoorbeeld accountants, advocaten, banken, ingenieursbureaus, regionale ontwikkelingsmaatschappijen, de Syntens organisatie, en andere. Dat gebeurt echter succesvoller als gebruik gemaakt wordt van de beschikbare knowhow en ervaring ten aanzien van samenwerking. Er lijkt een nieuwe groep van bemiddelaars te ontstaan die connecties maakt tussen partijen die in het innovatieproces actief zijn (Nambisan en Sawhney 2007). De overheid zou de ontwikkeling van deze intermediairs kunnen bevorderen, eerder dan zelf als tussenpersoon het mijnenveld van samenwerking te betreden, waarin de overheid last krijgt met haar plicht tot openbare verantwoording en bovendien gegijzeld kan worden door belangen.
\end{abstract}

Er is een tegen vertrouwen ingaande tendens om steeds meer te sturen op het meten van prestaties als basis voor 'afrekening'. Dat kan goed zijn voor de exploitatie, maar kan exploratie in de weg zitten. Eerder noemden we al het dilemma van beheersing en flexibiliteit. Beheersing vergt normering, standaards, toezicht 
en administratie, die hoge transactiekosten kunnen geven en de beroepsuitoefening, creativiteit, intrinsieke motivatie en innovatie in de weg kunnen zitten. Exploratie vergt een zekere ruimte voor experiment en voor afwijking van vastgestelde normen of standaards.

De sluiting ter wille van exploitatie kan de opening ter wille van exploratie in de weg zitten. Welke andere of aangepaste sturingsconcepten kunnen we gebruiken, die efficiënte exploitatie bevorderen, maar tegelijk ruimte geven voor exploratie? Dat is een fundamentele opgave voor management en organisatie. Het vervullen van die opgave vergt sociale innovatie, in de zin van innovatie van organisatie. Dit wordt nader besproken in hoofdstuk 7 .

Een goede institutionele basis voor vertrouwen is een belangrijke vestigingsplaatsfactor. Dat geldt vooral voor innovatie, maar ook breder, voor de beperking van transactiekosten in excessieve juridische beheersing, zoals bijvoorbeeld gebruikelijk in de vs. De overheid heeft daar een taak. Die omvat de gebruikelijke instituties van wet en recht die vooral gericht zijn op formele, op dwang gebaseerde beheersing van relationele risico's, maar ook instituties in de vorm van gebruiken, normen en waarden. Het voorbeeld dat de overheid geeft met haar eigen gedrag speelt daarin een belangrijke rol. Naast gebruikelijke argumenten van efficiëntie en effectiviteit voor samenwerking binnen de overheid en samenwerking met private partijen, zou de overheid het voorbeeld kunnen geven van goede samenwerking voor open innovatie en vertrouwen. ${ }^{2}$

\subsection{CONCLUSIE: OPENING IN VIERVOUD}

Innovatiebeleid bestaat niet alleen uit opening, ook uit sluiting. De overheid heeft een rol in het (laten) vastleggen en bewaken van formele instituties zoals wetten, veiligheidseisen, eigendom, opleidingseisen, en diploma's. Dat is nodig voor efficiënte exploitatie en voor het bieden van continuïteit en rechtszekerheid. Dergelijke sluiting vormt echter vaak een obstakel voor exploratie, die juist openingen vergt. Met de altijd aanwezige neiging tot behoud van wat bereikt is en bestaat, krijgt die noodzaak van ruimte voor exploratie in de vorm van vernieuwde openingen te weinig aandacht. Op grond van de analyse in dit hoofdstuk is er alle aanleiding voor de noodzaak opening als hoofdelement in de aanpak van innovatie centraal te stellen en wel opening in viervoud. En gegeven het feit dat spontane marktkrachten op die terreinen tekortschieten, liggen daar taken voor de overheid die momenteel in beleidsdiscussies onderbelicht zijn gebleven.

\section{Opening voor samenwerking}

Ten eerste ligt er een taak voor de overheid als het gaat om opening ten aanzien van samenwerking, zodat partijen kunnen profiteren van de diversiteit van kennis, op voldoende maar niet te grote onderlinge cognitieve afstand. Dat vergt open communicatie, gericht op wederzijds belang en vertrouwen, in 'voice', met vrijwillige transparantie. Het is in de mode om 'open innovatie' mooi te vinden, maar in werkelijkheid is men er slecht toe in staat, in overheid en bedrijfsleven. Er bestaat een 
blijvende, hardnekkige neiging om in alles de baas te willen spelen in plaats van de kunst van het geven en nemen te ontwikkelen. Goed onderhandelen is niet het onderste uit de kan halen, maar zoeken naar oplossingen van problemen die voor de ander zwaar wegen en van jou geen al te grote offers vergen. Samenwerken vergt een zeker evenwicht van belang. Dat is even wennen in een systeem waar men in lessen economie nog steeds doceert en leert dat economisch handelen puur een kwestie van eigenbelang is en dat organisatie en relaties gebaseerd zijn op het principe dat er altijd een opdrachtgever (principaal) en een uitvoerder (agent) is. Dat komt voor, en eigenbelang blijft meestal een voorwaarde, maar vaak en vooral in innovatie zijn vruchtbare relaties een kwestie van wederzijds belang en zijn partners elkaars opdrachtgevers en uitvoerders. Er staat geen 'baas boven baas' en dat maakt de samenwerking lastig maar niet onmogelijk. De kunst daarvan is te leren en we weten veel over hoe het kan. Het is van groot belang dat overheid en bedrijfsleven de kunst van dergelijk samenwerken leren. Nieuwe, daarbij passende intermediairs kunnen daarin een rol spelen, en dit geeft perspectief voor een nieuwe branche van zakelijke dienstverlening.

\section{Opening naar buiten}

Ten tweede opening naar buiten, naar nieuwe contexten van toepassing, onder andere in het buitenland, van binnen naar buiten en van buiten naar binnen, als opening naar nieuwe uitdagingen en inzichten, als basis voor ontdekking. Eerder gaven we al aan wat het belang daarvan is als prikkel en inspiratiebron voor innovatie; om in exploitatie het pad van exploratie te betreden. Er is een institutionele logica die dit tegenhoudt. Een regering wil zich profileren met nationaal beleid om de eigen kiezers tevreden te stellen. Zij heeft geen belang en ook weinig formele competentie om grensoverschrijdende programma's op te stellen, terwijl die wel nodig zijn. Zo komt zij ertoe om nationaal partners aan elkaar te koppelen die zich juist los zouden moeten maken voor nieuwe relaties elders. Door subsidies wordt men verlokt om de verkeerde partners te kiezen.

\section{Opening voor ideeën}

Ten derde opening voor ideeën, creaties en ondernemerschap van buitenstaanders. Dat vergt een kritische blik ten opzichte van gevestigde belangen en hulp bij het omzeilen en opruimen van obstakels voor toegang. Het gaat hier niet alleen om gevestigde belangen die de creatieve destructie van innovatie proberen tegen te houden, of om complexiteit van regelingen en bureaucratie, die vooral voor kleinere bedrijven lastig zijn. Alleen dat zien geeft een onderschatting van het probleem. Het gaat er ook om dat bestaande producten en markten zijn verweven met instituties (zoals technische standaards, veiligheidseisen, opleidingen, distributiekanalen, en gewoonten) die zich hebben gevoegd naar eerdere innovaties en waar de nieuwe innovatie niet in past. Het lastige daarvan is dat men niet kan zeggen dat die slecht zijn. Ze waren goed voor een efficiënte en volle benutting van wat eerder bedacht was. Maar dat neemt niet weg dat ze voor verdere innovatie een obstakel vormen. Vooral nieuwe bedrijven hebben niet de tijd, middelen en kennis om die obstakels te onderkennen en te overwinnen of vermijden (zie tekstbox 3.10). 
Innoverende ondernemers stuiten nogal eens op obstakels van gevestigde belangen, marktstructuren en instituties. Om hen te helpen dergelijke obstakels te omzeilen of op te heffen is bij het ministerie van Economische Zaken een interdepartementaal 'Koplopersloket' ingesteld. We citeren uitspraken van enkele ondernemers uit een evaluatie van het Koplopersloket (Competentiecentrum Energietransities 2006: 10).

"Er zat geen schot in onze discussies met de directie afval (van VROM) over het feit dat afbreekbare bioplastics niet in de groenbak mogen. En grote afvalverwerkers probeerden dat bovendien te voorkomen. Door interventie van het Koplopersloket is op hoog niveau composteren als een serieuze optie op de agenda gezet." (Rodenburg, Jongboom)

"Voor de bouw van een nieuwe fabriek in Zeeland was een vergunning nodig. Wij waren onvoldoende bekend met de regelgeving rond alcohol om te weten dat het veel uitmaakt of alcohol synthetisch of biologisch wordt geproduceerd. Het advies van het Koplopersloket heeft ons 4 tot 5 maanden tijdwinst in de vergunningverlening opgeleverd." (Weissman)

“Wij wilden een fabriek opzetten voor 'waste paper mining'. Dit idee bleek veel weerstand op te roepen bij de gevestigde partijen in de papierbranche. Door de lobby van die partijen bij EZ werd het idee van tafel geveegd. Dit was aanleiding om het Koplopersloket om hulp te vragen." (Zwart)

\section{Opening voor verrassing}

Ten vierde opening voor verrassing tijdens processen van innovatie. Dat vergt ruimte voor experimenten, voor afwijken en voor het falen van aanvankelijke verwachtingen. Dat vergt wellicht andere vormen van verantwoording, niet op basis van vooraf vastgelegde uitkomsten, maar van het proces dat verassing toelaat en verantwoording achteraf op basis van wat er feitelijk uitgekomen is. De implicatie is ook dat men vanuit een programma in een bepaalde technologie of bedrijfstak ergens anders uit kan komen, en dat daar dan ook de ruimte voor moet zijn.

Deze viervoudige opening voor innovatie haakt in op het 'hoe' van innovatie, en vormt daarmee een belangrijke aanvulling op een innovatiepraktijk waarbij innovatie vaak werd geformuleerd binnen de bandbreedten van gevestigde spelers ('wie'), van tevoren vastgestelde doelstellingen ('wat'), nationale programma's, geïsoleerde activiteiten en relaties waarbij opening niet vooropstond.

In verband daarmee is een tweede thema dat door de hoofdstukken heen loopt het vraagstuk hoe we exploitatie en exploratie op elkaar aan moeten laten sluiten, in een 'cyclus van innovatie'. De samenhang tussen de vier vormen van opening en de cyclus wordt geillustreerd in figuur 3.3. De centrale beleidsvraag is hoe we die cyclus draaiende kunnen houden door het op de juiste plaats in de cyclus creëren van de juiste opening.

Samengevat is de samenhang als volgt. Wanneer men in de exploratiefase een uitvinding genereert wordt die onderworpen aan selectie op technische en commerciële levensvatbaarheid om tot een innovatie te komen. Om te overleven 
Figuur 9.1 Vormen van opening in de cyclus van innovatie

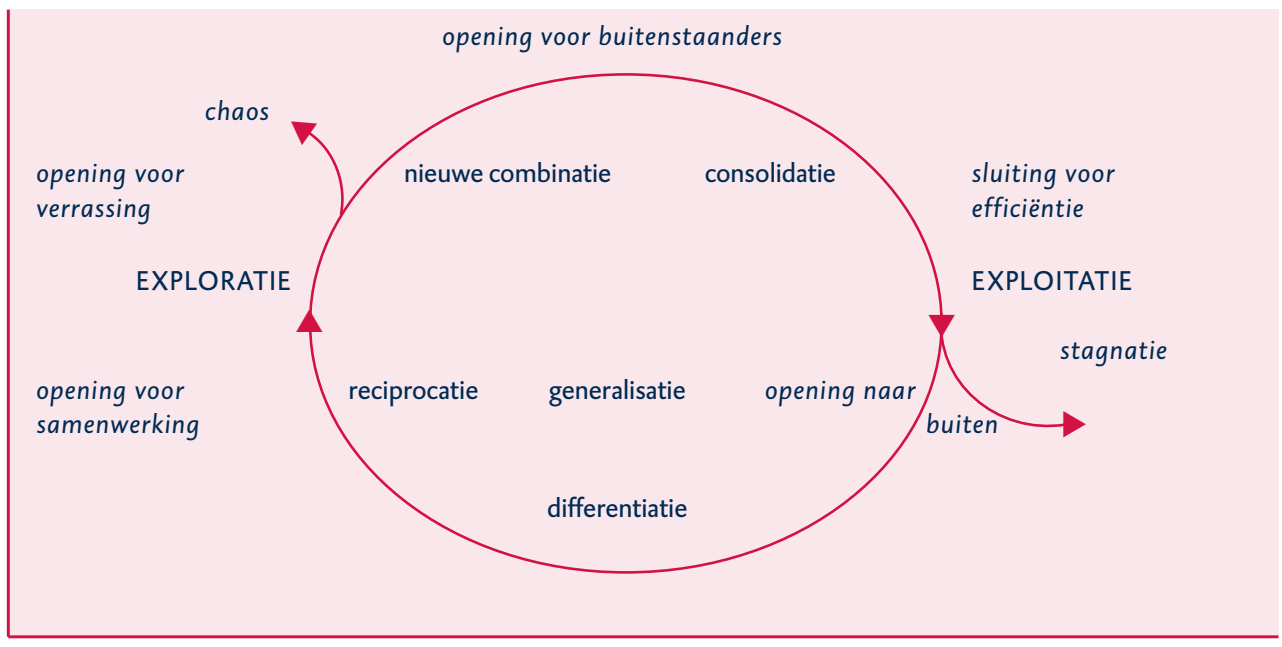

moet de innovatie ook passen in bestaande instituties en marktstructuren, en daar is aandacht van de overheid vereist om opening te bieden voor buitenstaanders die daar niet doorheen komen. Nadat een innovatie is doorgebroken en zich verspreidt, treedt sluiting op in de zin dat markten en andere instituties zich voegen naar optimalisatie ervan. Concurrentie zorgt voor efficiënte allocatie en barrières daartoe dienen te worden voorkomen. Naarmate de markt verzadigd raakt is er een prikkel om de prijsconcurrentie te verminderen door differentiatie van producten en om nieuwe toepassingen te zoeken. Om niet te stranden in stagnatie vergt dit opening naar buiten, voor toepassing en ontwikkeling in nieuwe omgevingen met nieuwe uitdagingen en bronnen van inspiratie, in andere bedrijven of in zelfstandig ondernemerschap, andere bedrijfstakken, andere regio's, andere markten en andere landen. Dergelijke verandering van context kan buiten worden gezocht, maar kan ons ook van buitenaf overkomen. Daar ontmoet men nieuwe uitdagingen die nopen tot aanpassing, in differentiatie, in eerste instantie vanuit bestaande repertoires en waar dat niet lukt in nieuwe combinaties met lokale praktijken, dat opening vergt voor samenwerking met andersdenkenden, waarbij men er verstandig aan doet te zoeken naar partners op optimale cognitieve afstand. Dit leidt vaak tot hybriden of hopeful monsters (Gould 1977) die de basis bieden voor verkenning van nieuwe combinaties, maar oplopen tegen inconsistenties en inefficiënties van het geheel, waardoor prikkels en inzicht ontstaan voor een andere architectuur (Henderson en Clark 1990) of basislogica, in een nieuwe configuratie van oude en nieuwe elementen. Dat levert onvoorzienbare nieuwe vormen en dit vergt opening voor de verrassing van een meer radicale innovatie.

In de volgende hoofdstukken worden de verschillende facetten van opening geconcretiseerd, en wordt aangegeven hoe die vormen van opening bereikt kunnen worden. 


\section{NOTEN}

$1 \quad$ Dit geeft toenemende meeropbrengsten van kennis: meer kennis geeft een beter vermogen om nieuwe kennis te absorberen. In genoemde studie werd echter ook een effect gevonden van verminderende meeropbrengsten: naarmate men meer weet wordt het moeilijker nog iets nieuws te vinden. Kortom: men kan het nieuwe beter absorberen maar moeilijker vinden.

2 Interessant is een recent initiatief van de Belastingdienst om met (grote) bedrijven convenanten aan te gaan voor wederzijds belang, onder andere in reductie van transactiekosten en vergroting van snelheid van afhandeling, door samenwerking en op vrijwillige transparantie gebaseerd vertrouwen. 


\section{PRINCIPES VOOR BELEID}

Het doel van dit rapport is te onderzoeken hoe de kwaliteit van het Nederlandse innovatieproces kan worden verbeterd. Een vraag die daarbij opkomt is wie die verbeteringen tot stand moet brengen. Met andere woorden: is overheidsbeleid voor innovatie nodig? Schieten markten en private sectoren tekort als het gaat om innovatie? Welke andere tekortkomingen zijn er en wat zijn de mogelijke tekortkomingen bij de overheid zelf? In hoeverre moet de overheid innovatie plannen en sturen en kan zij dat?

In de voorgaande hoofdstukken is gepleit voor opening in vier opzichten. Deze vierledige opening is verre van vanzelfsprekend. Ze moet vaak georganiseerd of zelfs afgedwongen worden door de overheid. De overheid creëert in de uitvoering van haar beleid echter zelf ook vaak onbedoeld obstakels voor de genoemde opening. Centraal in onze analyse staat systeemfalen in het innovatiesysteem (4.1). Vervolgens bezien we meer klassieke problemen van marktfalen (4.2) en overheidsfalen (4.3). Daarna plaatsen we enkele kritische kanttekeningen bij een van de centrale elementen van het huidige innovatiebeleid, het sleutelgebiedenbeleid (4.4), en breken we een lans voor een andere invulling van dat deel van het innovatiebeleid, namelijk het wegnemen van obstakels voor benutting van potentieel (4.5).

\subsection{SYSTEEMFALEN}

Wanneer er discrepanties bestaan tussen verschillende elementen van het innovatiesysteem kan er sprake zijn van systeemfalen. Dergelijke tekortkomingen of blokkades van het innovatiesysteem kunnen op verschillende manieren tot uiting komen.

\section{Uitingen van systeemfalen}

Een vaak gesignaleerde tekortkoming is het ontbreken van de juiste opleidingen en bijscholing - bij werknemers maar ook bij het management - die aansluiten bij nieuwe ideeën of ontwikkelingen (zie ook Innovatieplatform 20o6). Een ander tekort is de soms gebrekkige aansluiting tussen exploratie bij universiteiten en exploitatie in bedrijven. Verder is het de vraag of bedrijven beschikken over het juiste management en de juiste organisatie om exploratie en exploitatie met elkaar te verbinden en voorwaarden te scheppen die nodig zijn voor het functioneren van creatieve teams. Vraagtekens kunnen bovendien worden geplaatst bij de structuren van netwerken en regionale innovatiesystemen en bij het tekort aan vertrouwen en ook onvermogen tot samenwerking tussen bedrijven en andere organisaties. Ten slotte zit men vaak vast aan gevestigde belangen en posities die innovatie tegenhouden.

\section{Institutionalisering van markten}

Er is een onderlinge wisselwerking tussen markten en instituties. Markten vergen instituties, zoals onder andere blijkt uit de moeizame transitie van vroegere com- 
munistische landen naar een markteconomie. Markten leiden ook tot institutionele verandering. Dat is bij uitstek bij innovatieprocessen het geval. Succesvolle innovaties hebben tot gevolg dat aan de innovatie gerelateerde markten, onder andere die van toelevering, zich aanpassen aan de nieuwe situatie. Er vormen zich talrijke instituties die zijn gericht op de exploitatie van de innovatie. Daarbij kan worden gedacht aan distributiekanalen, technische standaards, protocollen voor de beoordeling van veiligheid (zie tekstbox 4.1), opleidingen en wettelijke regelingen (bijvoorbeeld van eigendom, aansprakelijkheid). Al eerder is betoogd dat die aanpassingen goed kunnen zijn voor de exploitatie, maar belemmeringen kunnen opleveren voor een volgende ronde van exploratie. Nieuwe exploratie moet zich veelal ontrekken aan de bestaande orde om een kans te krijgen.

\section{Box 4.1}

\section{Een 'catch-22'-situatie in veiligheid}

Van een innovatie in de kinderkleding werd door gevestigde partijen beweerd en aangekondigd dat zij niet veilig was. De innovator moest bewijzen dat het product wel veilig was, terwijl een dergelijk bewijs onmogelijk te leveren was en ook niet werd geëist voor bestaande producten. De ondernemer probeerde het product op veiligheid te laten testen door een onafhankelijke instantie, maar die liet weten dat het niet kon, omdat er geen gevestigd, geaccepteerd testprotocol was voor een dergelijk nieuw product. Die instantie had geen ongelijk, want zij was aansprakelijk voor aantoonbare, getoetste, betrouwbaarheid van hun testprocedures. Kortom, het nieuwe product moest bewijzen dat het veilig was omdat het nieuw was, maar dat kon niet omdat het nieuw was. Dit is wat men noemt een 'catch-22'-situatie.

\section{Patstelling tussen stakeholders}

Het komt vaak voor dat bij een innovatie verscheidene partijen betrokken zijn die in een patstelling terechtkomen, omdat zij zich ieder individueel in een voordelige positie proberen te manoeuvreren en moeite hebben om collectieve keuzes te maken (zie tekstbox 4.2). Deze collectieve keuzes zijn noodzakelijk om tot een succesvolle innovatie te komen. Vaak hebben de spelers elkaar nodig, maar zijn ze ook elkaars rivalen. Sommige oplossingen staan dichter bij de bestaande praktijk en kennis van de ene speler dan bij die van de andere. En als er dan eenmaal een evenwicht is gevonden, kan het problemen opleveren om weer een nieuw evenwicht te vinden als de situatie verandert. Soms is er dan een partij van buitenaf (zoals de overheid) nodig om een oplossing voor dit dilemma te vinden. Dit argument voor overheidsinterventie wordt, ook vanuit het bedrijfsleven, regelmatig aangevoerd.

Er zijn dus omstandigheden waarin een interventie van buitenaf nodig is om een vastgelopen situatie open te breken. Dit kan een taak voor de overheid zijn, maar er zijn ook andere partijen die dit kunnen. Bedrijven moeten de uitdaging aanvaarden om zelf capaciteiten te ontwikkelen die nodig zijn voor het opbouwen van goede samenwerking en netwerken, iets dat onontbeerlijk is in de moderne, op netwerken gebaseerde kenniseconomie. Voorts biedt de behoefte aan bemiddeling hierin kansen voor een nieuwe vorm van zakelijke dienstverlening. 
Het geval van het Electronisch Patienten Dossier (EPD) geeft een illustratie van systemische complexiteit als obstakel voor innovatie. In 1997 kondigde de toenmalige minister Borst van Volksgezondheid de start aan van invoering van het EPD, om efficiënte uitwisseling van medische gegevens mogelijk te maken. Met het EPD kan een arts de klachten van elke patiënt overzien: ziekten of allergieën, medicatie, contra-indicaties enzovoorts. Dit helpt om medische fouten te voorkomen en om betere zorg te verlenen. Foute medicatie is de oorzaak van ongeveer 9o.ooo ziekenhuisopnamen per jaar. De voornaamste oorzaak is dat apotheken, artsen en ziekenhuizen elkaars recepten niet kennen. De directe kosten bedragen $€_{300}$ miljoen per jaar. Het voordeel van het EPD is dat gegevens niet telkens opnieuw hoeven te worden ingevoerd en dat laboratoriumonderzoek niet telkenmale hoeft te worden herhaald. Ook de dienstverlening aan patiënten wordt beter. Wanneer zij beschikken over hun eigen medische gegevens kunnen ze beter beslissingen bespreken met artsen en andere werkers in de gezondheid.

Ondanks deze voordelen is er tien jaar later nog steeds geen landelijk systeem operationeel. Hoe kan dat?

Vele verschillende schakels zijn er bij het EPD betrokken: huisartsen, tandartsen, ziekenhuizen, apotheken (binnen en buiten ziekenhuizen), thuiszorg, psychotherapeuten, fysiotherapeuten, kraamzorgers en verpleegsters. Zij hebben allen hun eigen belangen en consensus is een probleem. De implementatie van het EPD in ziekenhuizen is moeizaam. Ziekenhuizen hebben alle hun eigen bestuur van wie instemming vereist is. Binnen ziekenhuizen zijn er vaak niet minder dan twintig specialismen met hun eigen werkwijzen. Negatieve ervaringen met automatisering kweken scepsis. Alle partijen hebben hun eigen aanpak en infrastructuur van automatisering. De meeste diensten hebben al een eigen systeem om gegevens op te slaan. Dit alles moet op elkaar afgestemd worden. In sommige gevallen is de communicatie tussen systemen al geregeld, bijvoorbeeld tussen huisartsen en apotheken. Daar bestaat een remmende voorsprong: vernieuwing vergt verandering van bestaande systemen. Velen zijn niet gretig, omdat ze tevreden zijn met hun eigen systeem. Huisartsen moeten hun activiteiten vertalen in standaard diagnostische codes. Ze zijn onzeker of het nieuwe EPD-systeem aan hun behoeften zal voldoen. De kosten van verandering zijn hoog. Aansluiting aan het nieuwe systeem kost een huisarts ongeveer $€$ 4.50o. Dat bedrag kan op termijn worden terugverdiend maar de initiële kosten vormen een obstakel. Het systeem kan ook leiden tot verlies van inkomen, juist omdat het behandelingen kan verminderen. Het systeem leidt er bovendien toe dat gegevens voor andere gezondheidswerkers toegankelijk worden. Dit leidt tot verlies van autonomie en macht en geeft anderen inzicht in fouten. Toegenomen marktwerking in de zorg verscherpt de angst. Er zijn ook problemen in de bescherming van privacy. Een zorg is ook bescherming tegen hackers.

Er is ook marktfalen. Er is geen effectieve vraag, omdat patiënten, die uiteindelijk de meeste baat erbij hebben, geen actoren zijn op de markt. Omdat zorgwerkers geen expertise hebben in ICT, zijn ze afhankelijk van de betrouwbaarheid van leveranciers. Er zijn ook lock-in-effecten: het is erg lastig om over te stappen naar een andere leverancier. Het systeem kan niet worden uitgeschakeld tijdens het zoeken naar een andere leverancier (Van der Geest en Heuts 2008). 


\section{Rol voor de overheid}

Als bij gebrek aan geschikte alternatieven dan toch de overheid moet ingrijpen, is het belangrijk dat dit niet verdergaat dan nodig is en dat zij zich terugtrekt zodra dat mogelijk is. Er lijkt behoefte te zijn aan een 'deblokkagebrigade' ${ }^{1}$, die gespecialiseerd is in het beheersen van complexe relaties en de bevoegdheid heeft om te opereren op diverse niveaus en terreinen binnen en tussen departementen. Deze brigade zou te hulp kunnen worden geroepen wanneer zich systeemgebonden problemen voordoen die marktpartijen (nog) niet zelf op kunnen lossen. In het geval van het Elektronisch Patiënten Dossier (zie tekstbox 4.2) lijkt alleen de overheid in een positie te zijn om de ontwikkeling vlot te trekken. Toch is een succesvolle implementatie nog ver te zoeken, met name omdat patiënten niet of nauwelijks in staat worden gesteld invloed uit te oefenen.

Een 'deblokkagebrigade' heeft niet alleen direct nut maar ook indirect merites. De ervaringen en inzichten die de brigadiers opdoen vormen een basis voor leren door de overheid omtrent de oorzaken van blokkades en mogelijkheden die op te lossen, vooral waar het gaat om door de overheid zelf veroorzaakte blokkades.

\subsection{MARKTFALEN}

Vanuit een evolutionair perspectief op innovatie vormt de markt een belangrijk selectiemechanisme, naast bedrijfsinterne selectie van ideeën, projecten en producten en selectie door regulering. Maar de markt kan ook tekortschieten, zodat bedrijven niet het voortouw nemen. Een bekend marktfalen treedt op bij activiteiten van publiek belang waarbij externe effecten optreden. Dat betreft vraagstukken als gezondheidszorg, onderwijs, infrastructuur, mobiliteit, energie, natuur en milieu, veiligheid, en - in toenemende mate - watervoorziening en -beheer. Indien bedrijven niet verleid kunnen worden om maatschappelijk benodigde keuzes te maken die voor hen verkeerd zouden kunnen uitpakken, moet de overheid dit doen. Dat vergt dan ook acceptatie van het risico van verkeerde keuzen, dat wil zeggen acceptatie van het feit dat innovatieve initiatieven vaker falen dan slagen.

Een veelgehoord probleem bij innovaties is dat een innoverend bedrijf niet 100 procent zeker is van de opbrengsten van zijn investeringen en daarom de innovatie niet ter hand neemt. Volgens de gangbare economische theorie heeft in zo'n geval de kennis en kunde van het bedrijf te lijden van marktfalen in de vorm van niet-uitsluitbaarheid, waardoor concurrenten met de innovatie aan de haal kunnen gaan (spillover). Bij nader inzien is dat probleem niet zo groot als wel wordt verondersteld. Dit komt omdat kennis en kunde als gevolg van cognitieve afstand en een beperkte absorptiecapaciteit zich niet altijd even gemakkelijk verspreiden, oftewel sticky zijn. Dat kan bescherming door middel van octrooien hier en daar minder urgent maken, vooral als we in aanmerking nemen dat er ook andere mogelijkheden zijn om intellectueel eigendom te beschermen, zoals snelheid van ontwikkeling (relatief tot snelheid van 'spillover', in aanmerking genomen de 'stickyness' van de betreffende kennis), en de noodzaak van complementaire kennis en activa om de kennis commercieel te benutten. 


\section{Onvoldoende verspreiding van kennis}

De keerzijde van deze medaille is echter dat de markt vaak tekortschiet bij de verspreiding van innovatie. 'Kennisoverdracht' is in dat opzicht een misleidende term. Kennis wordt bij overdracht vervormd, getransformeerd. Bedrijven met een beperkte capaciteit om kennis op te nemen kunnen innovatieve kansen niet goed benutten. Dit is vooral voor kleinere en meer traditionele bedrijven een probleem: door hun geringe omvang en beperkte niveau van kennis missen zij gespecialiseerde expertise. Bovendien is kennis vooral binnen meer traditionele bedrijven vaak in hoge mate impliciet en stilzwijgend (taciet) aanwezig: er is sprake van al doende leren en niet van formele kennisoverdracht. Impliciete, taciete kennis is vanzelfsprekend voor degene die deze kennis bezit. Daardoor is het moeilijker om kritiek te leveren op de bestaande kennis en praktijk, zodat innovaties minder snel worden geadopteerd. Het gebrek aan absorptiecapaciteit en een hoge mate van impliciete kennis leiden tot wat men 'cognitieve' transactiekosten zou kunnen noemen en voor veel kleine bedrijven zijn deze relatief hoog (Nooteboom 1993). Dat is een goede reden om kennisoverdracht naar kleine bedrijven te subsidiëren.

\section{Box $4.3 \quad$ Syntens}

De stichting Syntens (voorheen 'Innovatiecentra') is een gesubsidieerde instelling voor kennisoverdracht aan het mkb. Enkele jaren geleden was de vraag aan de orde of die subsidie moest worden afgeschaft, zodat men de advisering aan de markt kon overlaten. Vanwege cognitieve transactiekosten en de schaaleffecten daarin is een dergelijke dienst commercieel echter niet levensvatbaar. Bij commercialisatie zou een verschuiving optreden naar ondersteuning in exploitatie eerder dan naar stimulering van exploratie en naar grotere bedrijven waar de transactiekosten lager zijn maar die niet de doelgroep vormen.

\section{Te sterke concurrentie}

In hoeverre is concurrentie goed voor innovatie? In tegenstelling tot wat vaak wordt gedacht is concurrentie geen simpel begrip en de effecten ervan op innovatie zijn gemengd. Prijsconcurrentie geeft prikkels om producten te differentiëren. Dit is een vorm van innovatie maar die leidt tot vermindering van prijsconcurrentie. Concurrentie kan ook een prikkel geven om te zoeken naar meer radicale innovaties die bestaande producten verdringen. Zoals we al eerder zagen, gaat exploratie echter samen met onzekerheden op het gebied van gewenste en realiseerbare doelen, middelen en de verbanden hiertussen, en de rollen en belangen van betrokken partijen. Dat vergt een iteratief proces van zoeken en proberen, waarvoor ruimte nodig is in tijd, geld en andere middelen. Prijsconcurrentie kan beletten dat die ruimte wordt gegund. Concurrentie kan leiden tot verhoging van efficiëntie en die kan de slack bieden die nodig is voor exploratie, maar alleen als dat efficiëntievoordeel ten opzichte van de concurrentie ook behouden kan blijven. Dat vergt inperking van de concurrentie. Deze vorm van marktfalen wordt pas sinds kort erkend. De tekortkoming is in dit geval niet dat de productmarkt niet functioneert, maar dat deze juist te goed functioneert: de concurrentie is zo 
sterk dat dit ten koste van aanhoudende exploratie gaat. Volgens Lester en Piore (2004) is dit een van de redenen dat het bedrijfsleven bezuinigd heeft op fundamenteel onderzoek, of dit zelfs helemaal heeft laten vallen en dit steeds meer overlaat aan universiteiten.

\section{Optimale flexibiliteit}

Voor een goede samenwerking tussen betrokken partijen op het gebied van innovatie is een minimale periode van samenwerking nodig om te investeren in onderling begrip en vertrouwen voor het overbruggen van de cognitieve afstand die voor innovatie vruchtbaar is. Daarom moet gestreefd worden naar optimale in plaats van maximale flexibiliteit van relaties. Relaties moeten voldoende continuïteit bieden om investeringen in onderling begrip en vertrouwen rendabel te maken, maar niet zo lang dat zij leiden tot rigiditeit en te weinig cognitieve afstand. Dit heeft implicaties voor het mededingingsbeleid. Dat zou ruimte moeten laten om vormen van samenwerking waarin geïnvesteerd wordt om de cognitieve afstand optimaal te kunnen benutten, lang genoeg te laten duren, zelfs als dit betekent dat tijdelijk sprake is van exclusiviteit waardoor de concurrentie dus beperkt wordt.

Zoals we al eerder hebben gesteld, wordt inventie vooral gestimuleerd door de interactie tussen exploitatie en exploratie De mobiliteit van arbeidskrachten speelt hierbij een aanzwengelende rol, want zij bevordert de verspreiding van nieuwe praktijken en onderzoeksactiviteiten. Daarom is roulatie van personeel tussen afdelingen, of tussen organisaties die zich specialiseren in exploitatie en die welke zich specialiseren in exploratie, van groot belang.

Ook binnen organisaties geldt echter de logica dat een bepaalde continuïteit van werkrelaties is vereist om te kunnen profiteren van de specifieke investeringen in wederzijds begrip en vertrouwen. In het bedrijfsleven geldt dit ook voor de bedrijfsleiding. Deze mag niet te snel wisselen, omdat de investeringen die nodig zijn voor het opbouwen van netwerken, wederzijds begrip, inzet en vertrouwen dan niet meer gedaan worden. Uitvliegen is goed, maar een duiventil niet.

\subsection{OVERHEIDSFALEN}

Ten aanzien van innovatie draagt de overheid de klassieke verantwoordelijkheid voor de borging van publieke belangen (milieu, veiligheid, onderwijs, etc.), maar ook voor gunstige randvoorwaarden en een stimulerend klimaat voor innovatie. Vanuit evolutionair perspectief is het een taak van de overheid om de markt en het innovatiesysteem zo te laten functioneren dat zij de benodigde creatie van variëteit, selectie en transmissie kunnen bieden. De overheid dient het falen daarvan te voorkomen, maar zij kan zelf ook falen. De overheid draagt verantwoordelijkheden ten aanzien van het systeem, maar innovatie laat zich niet ontwerpen, plannen en dirigeren.

\section{Beperkt zicht op kennis in de samenleving}

Wellicht het belangrijkste falen van de overheid ligt in het feit dat zij slechts beperkt zicht en greep kan hebben op de gevarieerde en meer of minder eigen- 
zinnige en lokale kennis en inzichten in de samenleving. Beter dan te pretenderen dat de centrale overheid mogelijkheden en beperkingen kan overzien, is het om de verspreide diversiteit aan kennis in de samenleving aan te boren voor de vorming en uitvoering van beleid (WRR 2006a).

\section{Belanghebbend beleid}

De overheid kan verwikkeld raken in gevestigde belangen. Zij heeft de kennis en steun van bedrijven nodig bij het opzetten van goed gerichte innovatieprogramma's. Het risico bestaat dat het beleid ingekleurd raakt door het perspectief en wellicht ook het belang van die gesprekspartners. Men kan niet bij voorbaat uitsluiten dat bedrijven met de ontwikkeling van innovatieprogramma's louter meedoen om die te vertragen zodra potentiële ontwikkelingen niet blijken te passen in bestaande competenties en investeringen (competence destroying innovation). Het gevaar kan dan ontstaan dat door de betrokkenheid van de overheid de barrières voor buitenstaanders en ondernemers nog groter worden dan ze vaak al zijn. Juist kleinere ondernemers die druk bezig zijn met innovatie missen de tijd en/of de middelen, ervaring, positie en invloed en het retorische vermogen, om een rol te spelen in de ontwikkeling en uitvoering van overheidsprogramma's. Dit staat de in dit rapport bepleite opening voor buitenstaanders in de weg. Het vergt speciale aandacht om bij de opzet van overheidsbeleid oog te hebben voor opening voor buitenstaanders.

\section{Verbrokkelde beleidsvorming}

Innovatie gaat dwars door gevestigde overheidsstructuren heen. Dit betekent voor specifieke innovaties dat de betrokken ambtenaren verspreid zijn over diverse ministeries en over verschillende geledingen binnen ministeries. Elk ministerie heeft zijn eigen publieke verantwoording en zijn eigen legitimering binnen de overheid. Dit levert vaak onduidelijkheid op voor bedrijven die betrokken zijn bij innovatieprogramma's (zie tekstbox 4.4). Ook het Innovatieplatform (2004) constateerde dat het bij de overheid ontbreekt aan één enkel aanspreekpunt voor bij een programma betrokken bedrijven. Het betreft hier de transactiekosten van het beleid.

\section{Box 4.4 Flowers en food}

Bij het sleutelgebied 'flowers en food' betrokken bedrijven moeten in bijeenkomsten voor de ontwikkeling van het programma zelf eenduidige, vaste commitments geven, maar worden geconfronteerd met wisselende representaties van verschillende geledingen van twee betrokken ministeries (LNV en EZ), die zelf met wisselende verwachtingen en voorwaarden komen, waardoor het moeilijk is om te komen tot een snelle en effectieve voortgang.

De vraag is hoe coördinatie en verantwoording kunnen worden geregeld zonder dat zij leiden tot vermijdbare vertragingen, irritaties en frustraties bij partners buiten de overheid. Er lijkt behoefte te zijn aan een 'accountmanager' bij de overheid, zodat er één aanspreekpunt ontstaat zoals gebruikelijk is in het bedrijfsle- 
ven. Diens bevoegdheden voor coördinatie zouden zich kunnen uitstrekken over alle afdelingen en niveaus van alle betrokken departementen, voor zover deze het betrokken onderwerp betreffen. Een accountmanager zou niet alleen coördinatieproblemen op kunnen lossen, maar zou ook een basis kunnen vormen voor beleidsleren bij de overheid (WRR 2006a). Door het aanstellen van een accountmanager voor de coördinatie tussen overheidsinstellingen kan de omvang van de druk op het gebied van regelgeving, voorschriften en processen in ieder geval in beeld gebracht worden. Hierdoor ontstaat de prikkel om deze te vereenvoudigen of te veranderen. Deze noodzaak is sterker dan wanneer het aan partners van buiten wordt overgelaten om de transactiekosten te betalen. Door ministeries zelf de transactiekosten te laten dragen is de kans groter dat deze kosten door middel van betere afstemming en integratie worden gereduceerd.

De opening voor verassing wordt hier ook bedreigd. Zoals eerder is beargumenteerd, is deze vooral van belang in die fasen van het innovatieproces waar exploratie een belangrijke rol speelt. Deze opening voor verrassing wordt bedreigd door inhoudelijke specificatie vooraf van producten en prestaties (deliverables) die moet worden geleverd als conditie voor uitkering van een subsidie. Een alternatief is om aan het voortgangsproces een projectmanager te koppelen, die verantwoordelijk is voor de voortgangsbewaking, de goedkeuring van eventuele koerswijzigingen en de beoordeling van uitkomsten die afwijken van aanvankelijke verwachtingen, inclusief leerzaam falen. Een accountmanager zou dus niet alleen de taak hebben om contacten met de overheid te coördineren, maar ook een taak moeten vervullen bij de verantwoording van voortgang en uitkomsten, en veranderingen daarin (zie tekstbox 4.5). Een alternatief is om voorwaarden te formuleren die niet betrekking hebben op de inhoud van de uitkomst maar kwaliteitsmaatstaven daarvan, zoals publicaties, octrooien, licenties, werkbaarheid van prototypes, of peer review, inclusief beoordeling van de nuttige leerervaring van falen.

\section{Box 4.5 EU-kaderprogramma}

\footnotetext{
Het EU-kaderprogramma voor samenwerking in onderzoek heeft lange tijd gewerkt met het model van de accountmanagers, programmamanagers geheten. Bij eerdere versies van het programma waren de programmamanagers zelf in de uitvoering betrokken, zodat zij eerder konden beoordelen of koerswijzigingen nodig of gewenst waren. Eventuele conflicten konden zij snel oplossen.

De programmamanagers zijn echter uit het proces teruggetrokken en de monitoring van het proces is geformaliseerd en daardoor meer rigide geworden. De reden hiervoor lijkt te zijn dat men vraagtekens heeft bij de onafhankelijkheid van de programmamanagers. Het moet mogelijk zijn garanties daarvoor in te bouwen. Een andere reden was dat het aantal projecten zo gegroeid is dat een nauwe betrokkenheid van programmanagers niet meer betaalbaar was. Maar hier is dan een afweging op zijn plaats: de kosten van extra tijd voor programmamanagers tegen betere flexibiliteit en innovatieve kwaliteit van de projecten.
} 
Een vraag is dan of professionalisering van uitvoering en toezicht op afstand van de overheid de efficiëntie bevordert. Bij uitvoering op afstand ontstaat mogelijk het gevaar dat het leren op basis van die uitvoering - nodig voor nieuwe beleidsontwikkeling - wordt gehinderd. Zoals aangegeven in hoofdstuk 3 moet exploratie onder andere geïnspireerd worden door exploitatie, ook bij de overheid. Roulatie van personeel dat betrokken is bij de twee segmenten van ontwerp en uitvoering van beleid is een mogelijkheid. De vraag die dan rijst is of de beloningsstructuren voldoende vergelijkbaar zijn tussen de beleidsvormende en de beleidsuitvoerende functies. Als verschillen in cultuur van werk een obstakel vormen is dat misschien juist gezond, omdat men daarvan kan leren.

\subsection{HET SLEUTELGEBIEDENBELEID EN BACKING WINNERS}

Een saillant, veelbesproken en ook bekritiseerd instrument van het huidige innovatiebeleid is het beleid van 'sleutelgebieden'. Dit beleid richt zich op het stimuleren van kansrijke economische sectoren; momenteel zijn dat Flowers \& Food, High-tech systemen \& materialen, Water, Creatieve Industrie, Chemie, en Pensioenen \& Sociale Verzekeringen (Innovatieplatform 2007). De discussie daarover noopt tot een beschouwing. In oorsprong was dat beleid gebaseerd op het principe van backing winners: sectoren die hun potentieel al bewezen hebben (dit in tegenstelling tot picking winners-beleid waarbij nog niet is gebleken dat de gekozen sectoren kansrijk zijn). We geven een analyse van argumenten pro en contra dat principe, als espoused theory, maar we bezien ook de feitelijke uitvoering van het beleid (die inmiddels aan een aantal bezwaren is tegemoetgekomen), in een feitelijk gebruikte theory in use. Die laatste blijkt op een aantal punten te sporen met de behoefte aan opening.

\section{Box 4.6 Sleutelgebiedenaanpak Innovatieplatform}

\footnotetext{
"Het Innovatieplatform gelooft in een aanpak vanuit sterkte en van onderop. De sleutelgebieden zijn geselecteerd op ambitie, organiserend vermogen en commitment, economische kracht in relatie tot de Nederlandse concurrentiepositie en hoogwaardige kennis en technologie. Daar doen zich innovatieve kansen voor om onze internationale concurrentiepositie te versterken." (Innovatieplatform 2007: 6)
}

Het uitgangspunt voor keuzen in de besteding van publieke middelen moet voldoen aan drie voorwaarden. Uitgangspunt is dat het een kwestie betreft van prioritair maatschappelijk belang. Vervolgens moet er ook een noodzaak zijn, in die zin dat zonder overheidsinterventie de desbetreffende activiteit niet ondernomen zou worden. Dat kan bijvoorbeeld komen door een marktfalen, waardoor vanwege externe effecten of andere redenen bedrijven zich geen opbrengsten kunnen toe-eigenen en derhalve het initiatief niet nemen. Dit is het criterium van 'additionaliteit'. Ten derde moet men de consequenties van onzekerheid onder ogen zien en afwegen. Als het succes van de activiteit slecht voorspelbaar is 
- wat vooral in exploratie het geval is - zal men moeten accepteren dat de activiteit soms 'mislukt' in de zin dat het beoogde of gehoopte resultaat niet wordt bereikt. Deze drie voorwaarden zijn belangrijke toetsstenen van beleid, die toegepast moeten worden bij de aanwending van publieke middelen voor innovatie en derhalve ook op backing winners en het sleutelgebiedenbeleid.

De gedachtegang achter backing winners is als volgt. Zoals in hoofdstuk 2 is geconstateerd, zijn radicale doorbraken die nieuwe paden van ontwikkeling openen schaars, terwijl juist een bron voor toename van welvaart voortkomt uit die nieuwe ontwikkelingen en toepassingen en variaties daarvan. Dat roept de vraag op of een land zich volledig moet toeleggen op zelf ontwikkelen óf ook gebruik moet maken van wat anderen verzonnen hebben.

Dat een land met een moderne economie fundamentele R\&D moet verrichten is wel duidelijk. Vrijwel altijd blijkt dat men als voorloper forse winsten maakt uit innovatieve doorbraken voordat volgers op de wagen springen en de winst wegconcurreren. Voordeel is ook dat men als voorloper vaak het initiatief heeft in het bepalen van de standaards en instituties die goed passen, waarbij volgers zich aan moeten passen aan standaards die hun minder goed passen. Voorlopers zullen ook vaak de structuur van markten bepalen, inclusief mogelijke toetredingsbarrières. Voorloperschap vormt bovendien een aantrekkelijke omgeving voor de vestiging van andere voorlopers en van snelle volgers, met positieve gevolgen voor innovatiecapaciteit, werkgelegenheid en imago van een land.

Investeringen in opleiding en R\&D zijn dan ook nodig om de wisselwerking tussen onderwijs en onderzoek te stimuleren die de absorptiecapaciteit van een land bepaalt. Deze absorptiecapaciteit is noodzakelijk om een snelle volger te zijn (en inventies en innovaties van elders goed te kunnen benutten).

Men kan van een klein land als Nederland niet verwachten dat het grossiert in radicale, baanbrekende innovaties. In de meeste gevallen zal innovatie exploitatief, incrementeel of imitatief van aard zijn. Het is dus duidelijk dat ondernemers zich als volgers concentreren tot deze vormen van exploitatieve innovatie. Overheidsbeleid kan daartoe een prikkel geven, maar kan ook de voortrekker een duwtje in de rug geven.

De volgende vraag is dan welke gebieden 'wij' als natie moeten uitkiezen om voortrekkers in te zijn en om daar schaars publiek geld op in te zetten, accepterend dat we op andere gebieden volgers zijn. Een gedachte hierbij is ook dat men terwille van de efficiëntie moet streven naar 'focus en massa' en men versnippering en duplicatie van uitgaven moet vermijden. De verleiding voor beleidsmakers is groot om een keuze te maken op basis van de verwachte unieke sterke punten voor de toekomst. In een beleid van picking winners pretendeert men dergelijke voorspellingen van succes te kunnen maken. In de jaren tachtig werd in Nederland daarvoor gekozen met de keuze van een aantal 'speerpuntgebieden' (WRR 1980). Sindsdien heeft men geleerd dat vanwege de onzekerheid van een 
innovatie picking winners-beleid niet goed mogelijk is, omdat het moeilijk is te voorspellen wat toekomstige innovaties zullen zijn.

In 2003 pleitte de Adviesraad voor het Wetenschaps- en Technologiebeleid (AWT) voor een beleid van backing winners (AWT 2003), dat vervolgens vorm heeft gekregen in een beleid van 'sleutelgebieden', ingezet door het in 2003 opgerichte Innovatieplatform. De AWT-logica van backing winners is als volgt.

Toekomstig succes bouwt vaak voort op huidig succes, zodat huidig succes voorspellende waarde heeft voor toekomstig succes. Het succes van 'winnaars' heeft zich reeds in de markt bewezen, zodat zich hier de paradox van voorspelling van succes uit innovatie niet voordoet. Met andere woorden, huidig succes is indicatief voor 'comparatief voordeel' van Nederland. Misfits, fouten en gebreken zijn weggeselecteerd in het selectieproces van markten.

Hier is een aantal argumenten tegen in te brengen. Ten eerste is huidig succes alleen indicatief voor innovaties die niet de bestaande competenties, investeringen en marktposities vernietigen. Voor echt nieuwe dingen heeft succes zich nog niet kunnen manifesteren. Ten tweede hebben, zoals eerder aangegeven, succesvolle innovaties tot gevolg dat structuren van markten en velerlei instituties zich hebben gevoegd naar de exploitatie van de innovatie. Die aanpassingen waren goed voor exploitatie, maar kunnen belemmeringen opleveren voor een volgende ronde van exploratie, met name wanneer die bestaande competenties zouden vernietigen. Het inzetten op bewezen successen bevestigt dan dergelijke obstakels. Voorts is er het al eerdergenoemde probleem dat men door in te zetten op gevestigde successen het gevaar loopt dat men ook inzet op gevestigde belangen. Ook speelt het probleem dat men voorrang geeft aan partijen die hun belangen goed kunnen articuleren, die reeds de benodigde partners hebben, die de tijd hebben zich in te zetten voor het langdurige proces van het opzetten van een sleutelgebied en die de middelen hebben om de hoge transactiekosten te incasseren. Dat zijn veelal de grotere bedrijven en niet de vernieuwende kleine bedrijven die, juist omdat ze de handen vol hebben aan nieuwe ontwikkelingen en worstelen om het hoofd boven water te houden, geen tijd en middelen hebben om deel te nemen aan het complexe en langdurige proces van vormgeving en uitvoering van programma's.

Overwegingen van 'focus en massa' zijn minder vanzelfsprekend dan ze op het eerste oog lijken. Ten eerste zijn er naast voordelen ook nadelen van grote schaal ('massa'), zoals we tot onze schade ervaren hebben in de schaalvergroting in zorg en onderwijs. Ten tweede gaat concentratie van activiteiten ('focus') gepaard met verlies van diversiteit, en die is vooral voor innovatie van belang. Eventuele efficiëntievoordelen moeten daartegen afgewogen worden.

Voorts, en vooral, is het vermogen om successen te kunnen identificeren nog geen argument voor de noodzaak om die te steunen. Welk probleem lost 'backing winners' eigenlijk op? Waarom hebben winners steun nodig? Als zij worden geïdentificeerd op basis van hun succes in de markt, dan kunnen zij toch de 
ontwikkeling van hun verdere succes daarmee financieren? Er moet ook worden voldaan aan de voorwaarde dat zonder interventie van de overheid het voortbouwen op succes niet plaats zou vinden, bijvoorbeeld omdat daarvoor geen opbrengsten gegenereerd worden (het principe van additionaliteit). Als echter bedrijven met succesvolle producten problemen hebben bij de financiering van het opschalen en het in nieuwe markten brengen ervan, dan schort er iets aan de kapitaalmarkt, en moet daar ook de oplossing gezocht worden.

Kortom, backing winners draagt het gevaar van de bevestiging van bestaande structuren, instituties en belangen, met uitsluiting van vaak kleinere en juist sterk innovatieve buitenstaanders en van innovaties die creatief destructief zijn. Bovendien is vaak niet duidelijk waarom winners steun nodig hebben voor uitbouw van hun succes.

Succes dat in principe niet beloond wordt via de markt doet zich voor in universitair onderzoek. Daar is het daarom wel een goed idee om succes te belonen, met persoonsgerichte subsidies of prijzen bestemd voor het uitbouwen van het succesvolle onderzoek. Dergelijke prijzen bestaan al in Nederland, zoals de Spinoza-prijs voor senior onderzoekers en het Veni, Vidi, Vici-programma voor aankomende en opkomende onderzoekers. De prijs gaat ook niet naar de wetenschapper zelf, maar is bedoeld ter ondersteuning van zijn of haar onderzoek. Op de financiering van onderzoek gaat hoofdstuk 5 nader in.

\subsection{REALISATIE VAN ONBENUT POTENTIEEL}

Bij het debat over de feitelijke invulling van het beleid van sleutelgebieden met verschillende instanties en personen ${ }^{2}$ bleek dat het beleid wellicht beter getypeerd kan worden als een beleid voor het opheffen van obstakels voor het benutten van nieuw potentieel (zie tekstbox 4.7). Dan is er niet alleen een identificeerbare kans op succes, maar ook een noodzaak van steun. Dan zou interventie voldoen aan de voorwaarde van additionaliteit. Het past in deze benadering dat men die obstakels dan ook vooral helder moet kunnen expliciteren. In het voortgaande debat bleek wel dat men in toenemende mate tegemoet probeert te komen aan andere, hierboven genoemde bezwaren. Er worden meer pogingen ondernomen om ook kleine bedrijven bij de sleutelgebieden te betrekken, en om ook internationale contacten en samenwerking in te bouwen.

\section{Box 4.7 Onbenut potentieel buiten sleutelgebieden}

Als het gaat om het weghalen van obstakels voor de benutting van potentieel, waarom dan niet ook in andere dan sleutelgebieden? Waarom niet ook in gebieden waar zich nog geen bewezen succes heeft kunnen manifesteren? Waarom niet ook waar innovatie de basis voor bestaand succes vernietigt? Of willen we dat aan het buitenland overlaten? Innovatie en obstakels in de realisatie daarvan, doen zich overal in de economie voor. Innovatie is te fijnmazig om toe te schrijven aan bepaalde 
sleutelgebieden. Zoals eerder aangegeven loopt innovatie over de grenzen van sectoren, technologieën en landen heen. ${ }^{3}$

Ook hier zien we in de feitelijke ontwikkeling van de uitvoering van het sleutelgebiedenbeleid een opening naar tal van projecten waarvan de binding en herkomst met het oorspronkelijke sleutelgebied vrij los is. Het lijkt wel of het sleutelgebied aanleiding gaf om projecten voor innovatie te identificeren die zich ook elders voordoen. En dat is wat ons betreft uitstekend, in een meer generiek beleid om obstakels op te heffen, waar die ook de realisatie van belangrijk innovatief potentieel blokkeren.

In de praktijk van de afgelopen jaren lijkt een zekere convergentie te zijn ontstaan: de uitvoering van het sleutelgebiedenbeleid komt steeds meer in lijn met het eerder aangegeven pleidooi voor opening in viervoud. We zien groeiende aandacht voor het erbij betrekken van kleinere bedrijven (opening naar buitenstaanders), internationale samenwerking (opening naar het buitenland) en opening naar andere sectoren dan de benoemde sleutelgebieden. Het is echter vaak niet duidelijk hoe groot de noodzaak is van het wegnemen van obstakels voor additionaliteit.

\subsection{CONCLUSIE}

In dit hoofdstuk zijn twee typen falen besproken die een legitimatie bieden voor overheidsinterventie. Hiermee is echter niet gezegd dat overheidsingrijpen altijd gewenst is: de overheid kan zelf ook falen. Een terughoudende overheid is veelal beter dan een falende overheid. We hebben deze principes toegepast op een specifiek onderdeel van het Nederlandse innovatiebeleid, de zogenoemde sleutelgebiedenaanpak. Hieruit blijkt dat de uitgangspunten voor de sleutelgebiedenaanpak (espoused theory) niet in lijn zijn met de eerder geformuleerde principes voor beleid. In de praktijk lijkt er - gelukkig - een convergentie op te treden tussen de uitvoering van het sleutelgebiedenbeleid (theory in use) en de door ons geformuleerde principes voor beleid. In de toekomst zou innovatiebeleid van meet af aan al op deze principes gebaseerd moeten zijn, zodat ze sneller tot de hoognodige verbetering van de Nederlandse innovatiecapaciteit leidt. 


\section{NOTEN}

1 De inspiratie voor dit idee is mede ontleend aan de oprichting van de 'Kafkabrigade' van de Stichting Nederland Kennisland, die burgers bijstaat wanneer zij vastlopen in de bureaucratie.

2 Onder andere met het ministerie van Economische Zaken, het Innovatieplatform, de AWT. Voor documentaire evidentie hebben we gebruik gemaakt van EZ (2007).

3 We hebben bijvoorbeeld nog geen voorstel gezien om de detailhandel aan te wijzen als sleutelgebied, maar gelet op alle innovaties die daar plaats vinden zou daar wel aanleiding voor kunnen bestaan. Bezie bijvoorbeeld de revolutionaire effecten van streepjescode en ICT voor de dienstverlening, assortimentsvorming, logistiek, marketing en communicatie, kostenverlaging en verschuiving van macht van producenten naar detailhandel, en de ontwikkeling van handel via internet. 


\section{PRODUCTIE EN GEBRUIK VAN KENNIS}

Bij innovatie is wetenschappelijk en technologisch onderzoek de belangrijkste basis voor exploratie en vormen algemeen onderwijs en beroepsonderwijs de belangrijkste basis voor exploitatie (diffusie). Vanuit een evolutionair perspectief is onderzoek de belangrijkste bron van de creatie van diversiteit, naast ondernemerschap en kunst. De wetenschappelijke gemeenschap, met redacties en reviewers van tijdschriften, wetenschappelijke genootschappen, organisatoren van congressen en dergelijke, commissies voor de selectie van onderzoeksvoorstellen en promovendi, voor universitaire benoemingen en voor peer review, biedt de belangrijkste basis (forum) voor de selectie van ideeën. Voor de derde stap van evolutie, de transmissie van wat overleeft, hebben we publicaties, markten en onderwijs.

Daarnaast is onderwijs natuurlijk om meer redenen van groot maatschappelijk belang. In hoofdstuk 2 constateerden wij dat vooral de toepassing en verspreiding van kennis voor innovatie van belang zijn. Onderwijs is daarom wellicht belangrijker voor de economie dan onderzoek. Verschillende studies hebben aangetoond dat het in dienst nemen van vaardige afgestudeerden de voornaamste weg is waarlangs bedrijven economisch voordeel behalen uit fundamenteel onderzoek (Martin en Tang 2007). Onderwijs wordt gevoed door onderzoek. Beleid ten aanzien van wetenschap en onderwijs is een omvangrijk terrein en dit rapport buigt zich verder niet over onderwijs. Dat neemt niet weg dat ook voor innovatie goed onderwijs een prioriteit is en in de besteding van middelen moet dat belang worden afgewogen tegen het belang van bijvoorbeeld subsidies aan bedrijven. Wat aanbevelingen voor onderwijs betreft verwijzen wij naar de 'Kennisinvesteringsagenda' van het Innovatieplatform (2006).

In dit hoofdstuk richten wij ons op twee onderwerpen: de toepassing ('valorisatie') van wetenschappelijke kennis (5.1) en de financiering van wetenschappelijk onderzoek (5.2). Het eerste thema speelt in het innovatiebeleid een belangrijke rol, vanwege de in hoofdstuk 2 vermelde kennisparadox dat Nederland goed is in onderzoek maar niet in innovatie, waarbij we proberen een bijdrage te leveren aan een oplossing. Over de financiering van wetenschappelijk onderzoek bestaan ons inziens misverstanden die dienen te worden opgelost.

\subsection{VALORISATIE}

In het vorige hoofdstuk is het gebrek aan aansluiting tussen exploratie bij universiteiten en exploitatie bij bedrijven als onderdeel van het systeemfalen geïdentificeerd. Verbetering van die aansluiting heeft hoge prioriteit in het innovatiebeleid, in beleid gericht op meer zogeheten 'valorisatie'. We bespreken eerst de zogenoemde Technologische Topinstituten (TTI's), die zijn opgericht om op geselecteerde gebieden toegepast technologisch onderzoek te bevorderen. Vervolgens plaatsen we de bredere discussie over de relatie tussen universiteiten en bedrijfsleven in de context van de paradoxale relatie tussen exploratie (in universiteiten) 
en exploitatie (in het bedrijfsleven). Vervolgens ontwikkelen we het idee van third spaces. Dit zijn virtuele of fysieke organisaties voor interactie tussen universiteit en bedrijf, die deels zijn verbonden en deels afgeschermd van universiteiten en bedrijven om exploratie te beschermen tegen al te grote commerciële druk.

\section{Technologische topinstituten}

De aandacht voor valorisatie heeft geleid tot tal van voorstellen en maatregelen. Een daarvan is de ontwikkeling van TTI's. Een idee daarbij is ook om onderzoekers (mede-)eigenaar te laten zijn van octrooien, zodat ze nog meer gestimuleerd worden die te ontwikkelen en tot toepassing te brengen. Hierna volgen enkele punten van saillant belang.

Zoals aangegeven in hoofdstuk 2 zou de dominante aandacht voor TTI's geen belemmering moeten vormen voor pleidooien om innovatiebeleid wat minder exclusief te richten op wetenschap en technologie en ook aandacht te besteden aan niet-technologische aspecten van innovatie. Een belangrijk aspect daarvan is de organisatie van de schakels in het innovatiesysteem. Neem de schakel tussen universiteit en bedrijfsleven. Een belangrijke vraag daarbij is of toepassing van wetenschappelijke kennis plaats moet vinden binnen universiteiten, in bedrijven, of in samenwerking daartussen in een vorm van organisatie tussen de twee. De gedachte achter de TTI's gaat vooralsnog uit van het laatste. Vanuit de WRRprojectgroep hebben wij gesprekken gevoerd met vier universiteiten, vier TTI's, een hogeschool, twee middelgrote bedrijven, en drie Nederlandse multinationals over de plaats, de vormgeving, de taak en de financiering van de relatie tussen universiteiten en bedrijven. Hieruit kwam een beeld naar voren dat hieronder wordt samengevat.

\section{Accountmanagers}

Zoals eerder aangegeven gaat de vormgeving en uitvoering van door de centrale overheid gesubsidieerde programma's gepaard met hoge transactiekosten van coördinatie en vertraging. Er zijn hiervoor overigens goede argumenten over verantwoording van besteding van publieke gelden, in het verkrijgen van toestemming en afstemming tussen en binnen departementen. Dat vormt een hinderpaal voor betrokken bedrijven, maar ook voor onderzoekers. Dat was voor ons aanleiding met het idee te komen voor het instellen van accountmanagers die voor die coördinatie zorgdragen. De indruk bestaat dat de TTI's die functie momenteel vervullen. Zij leveren de institutionele kennis en contacten, de kundigheid, het geduld en de aandacht, en dragen de transactiekosten. Hier doen zich schaaleffecten voor: die kosten zijn efficiënter besteed als het gaat om een voldoende grote omvang van projecten en een acceptabel aantal ervan. Dit is een goede reden voor het bestaansrecht van de TTI's. De vraag blijft wel wat dan de prikkel is om de complexiteit van coördinatie binnen de overheid te reduceren, als dat probleem buiten de overheid geplaatst is. Hoe kan de overheid voor haar beleidsontwikkeling en organisatie dan leren van de ervaring uit die praktijk? De behoefte aan het instellen van accountmanagement blijft overigens bestaan waar die niet door TTI's geboden wordt. 


\title{
Exploratie en exploitatie
}

Hiervoor is al gesignaleerd dat het in de relatie tussen universiteit en bedrijfsleven niet alleen moet gaan om de toepassing van wetenschappelijk onderzoek, van universiteit naar bedrijven, maar ook andersom, van inspiratie van dat onderzoek vanuit ervaringen in de praktijk. Dat is een centraal punt in de overgang van een lineair naar een meer cyclisch model van innovatie, van wisselwerking tussen exploratie en exploitatie. Toepassing is een vorm van toetsing, en toetsing is onderdeel van wetenschap.

In de wisselwerking tussen exploratie en exploitatie moet men echter onderkennen dat exploitatie primair commercieel gedreven is, terwijl concurrentiedruk de basis voor exploratie kan bedreigen door de ruimte weg te nemen - in tijd en middelen - die nodig is voor verkenning en iteratie met betrekking tot onbekende doelen, middelen en de causale relaties daartussen (zie ook box 5.1).

\section{Box 5.1 Bell Labs}

\begin{abstract}
Lester en Piore (2004) claimen dat het succes van innovaties in de vs in de jaren 1990 toegeschreven wordt aan de toen opgevoerde druk van concurrentie. Maar er is ook de visie dat de Amerikaanse innovatiesuccessen de uitkomst zijn geweest van de vóór die tijd bestaande instellingen tussen universiteit en bedrijven, zoals de beroemde Bell Labs (die als platforms fungeerden voor de vermaarde Silicon Valley). Die zijn inmiddels vanwege de toegenomen concurrentiedruk afgeschaft. Mogelijk zijn daardoor bronnen van innovatie in de vs verdwenen. Dit beeld komt ook naar voren in de analyse van 'open innovatie' van Chesbrough (2006).

Het is een bekend verschijnsel en een bron van zorg dat het aandeel van bedrijven in fundamenteel onderzoek is afgenomen. Aannemelijk is dat deze afname een gevolg is van bewust beleid gericht op marktwerking en concurrentie.
\end{abstract}

Zoals al is aangegeven, is concurrentie in markten prima voor exploitatie en kan zij ook de opening verschaffen die nodig is om de stap te zetten van exploitatie naar exploratie. Maar zij kan ook de slack wegnemen die juist nodig is voor exploratie. Gevolg van deze ontwikkeling is dat exploratie is verplaatst van bedrijfsleven naar universiteit, waarbij we ervoor moeten oppassen dat de druk van commercie niet ook de basis daarvoor vernietigt. ${ }^{1}$ Kortom, de bronnen van exploratie aan universiteiten verdienen bescherming tegen al te grote druk van commercialisatie.

Dit neemt niet weg dat valorisatie in en inspiratie vanuit toepassing eveneens van belang zijn. De vraag is dan welke oplossing te vinden is voor koppeling met behoud van bescherming van bronnen van exploratie. Gezien het eerder geconstateerde gebrek aan valorisatie als een van de kernproblemen besteden wij hier de nodige aandacht aan.

\section{Tweerichtingsverkeer}

Een van de belangrijkste uitkomsten uit de gesprekken die wij met ter zake kundigen voerden (hun namen staan in bijlage II), is dat het ook voor hen duide- 
lijk is dat het in de relatie tussen universiteiten en bedrijfsleven inderdaad niet om eenrichtingsverkeer gaat, waarin door universiteiten gegenereerde kennis in bedrijven wordt benut. Veeleer is sprake van tweerichtingsverkeer, waarbij fundamenteel wetenschappelijk onderzoek ook wordt geïnspireerd door de praktijk. Theoretisch vloeit dit ook voort uit de analyse van de innovatiecyclus waarbij exploitatie en exploratie op elkaar voortbouwen. De meeste respondenten konden zich vinden in dat concept.

Een andere belangrijke uitkomst was dat het voor het stimuleren van exploratie meer zin heeft om samen ideeën en projecten te genereren rond een breed thema in plaats van projecten op voorhand al precies vast te leggen, waarna deelnemers erop in kunnen schrijven. Dit komt overeen met het idee dat innovatieprojecten zouden moeten inspelen op de diversiteit aan kennis en ideeën die verspreid is over verschillende organisaties en groeperingen, en met het uitgangspunt dat projecten moeten openstaan voor verrassingen en koerswijzigingen.

Ook om andere redenen bleek het onderscheid tussen exploitatie en exploratie in samenwerkingsprojecten nuttig te zijn. Exploitatie is ingebed in tamelijk concreet contractonderzoek, waarbij het bedrijfsleven de gewenste uitkomsten (contractueel) kan vastleggen. In lijn met het eerdere pleidooi voor optimale in plaats van maximale flexibiliteit, bleek dat het bij samenwerking ten behoeve van exploratie belangrijk is dat er voldoende tijd wordt genomen om elkaar te leren kennen en begrijpen (om zogezegd dezelfde taal te leren spreken) en een vertrouwensrelatie op te bouwen. In een dergelijke situatie leveren contracten (bijvoorbeeld voor het vastleggen van intellectueel eigendom) vaak juist extra problemen op, of kunnen zelfs contraproductief zijn. Tegelijkertijd dient er voldoende roulatie van betrokkenen te zijn om ervoor te zorgen dat de variatie aan ideeën groot genoeg blijft en er voldoende cognitieve afstand blijft bestaan.

\section{Intellectueel eigendom}

Over de bescherming van intellectueel eigendom en spillovers waren sommige respondenten van mening dat het hoog tijd is voor een versoepeling van octrooirechten. Om kennis te verwerven moeten onderzoekers ook zelf kennis aanbieden en risico's durven nemen in plaats van hun eigen onderzoeksbevindingen krampachtig te willen beschermen. Vaak speelt exploratie zich af in een fase waarin concurrentie nog geen grote rol speelt, waardoor er geen directe bedreiging voor de eigendomsrechten bestaat. Contracten hebben geen zin in een zo vroeg stadium (er is nog niets gedefinieerd dat vastgelegd kan worden), en iedereen heeft elkaar gewoon nodig om vooruitgang te boeken. Dat wil niet zeggen dat intellectuele-eigendomsrechten geen rol spelen, maar in het beginstadium van exploratie zijn zij vaak minder belangrijk. Octrooien die zijn gebaseerd op exploratie in de beginfase zijn waarschijnlijk al verlopen tegen de tijd dat de exploitatiefase is bereikt. In sommige gevallen werd bij octrooiering nog wel de mogelijkheid opengehouden voor eigen exploitatie, bijvoorbeeld op basis van een spin-off, hoewel ook daar het uitgangspunt was dat dit in de meeste gevallen zou liggen in bedrijven. In andere gevallen wordt eigen gebruik zelfs op voorhand uitgesloten. 
Een overweging daarbij is dat men bij huidige en toekomstige bedrijfspartners niet over wil komen als een potentiële concurrent.

\section{Flexibiliteit van relaties}

Verscheidene geïnterviewden gaven er de voorkeur aan exploratie min of meer op ad-hocbasis uit te voeren met verschillende partners in verschillende situaties. Het voordeel hiervan is de flexibiliteit. Andere respondenten kozen voor meer duurzame 'strategische' relaties, zodat de partijen konden werken aan wederzijds begrip en vertrouwen. Bij dergelijke relaties werd vaak ook tijdelijk personeel ter beschikking gesteld of werden werknemers uitgewisseld voor de duur van het project. Een aantal respondenten bleek huiverig te zijn voor een te nauwe band tussen bedrijfsleven en universiteiten. Dit zou de onafhankelijkheid van universiteiten kunnen beïnvloeden, waardoor zij zich niet goed meer van hun algemeen als belangrijk en legitiem beschouwde taak zouden kunnen kwijten, namelijk het verrichten van onafhankelijk fundamenteel onderzoek. Bovendien zouden anderen (politici, burgers) dan kunnen denken dat openbare instellingen werden ingelijfd door het bedrijfsleven.

\section{Third space}

Een mogelijke oplossing zou het creëren van een daadwerkelijke, fysieke third space tussen universiteiten en bedrijfsleven kunnen zijn in de vorm van een speciaal instituut, met eigen faciliteiten, dat is gericht op de interactie tussen bedrijfsleven en universiteiten en wordt gefinancierd door bedrijfsleven en overheid. Zo'n instituut dient de expliciete taak te krijgen om onderlinge contacten te bevorderen en gezamenlijke projecten op poten te zetten, waarbij cognitieve afstand wordt benut voor exploratie. Door dit instituut onafhankelijk te laten functioneren blijft de integriteit van universiteiten gewaarborgd en bestaat er geen gevaar dat het werk onder commerciële druk beperkt wordt tot exploitatie. Een voorwaarde is dat de deelname van wetenschappers als legitiem wordt beschouwd en dat de prestaties op een adequate manier worden geëvalueerd. Voor het bedrijfsleven geldt dat deelname aan het instituut moet worden gezien als een goede zet in de carrière binnen het bedrijf. Een third space kan ook nodig zijn om interdisciplinair onderzoek tot stand te brengen dat binnen universiteiten vaak niet van de grond komt. Zij zou misschien ook kunnen functioneren als een platform voor spin-offs. In dat geval kan het ook goed zijn om er participatiemaatschappijen bij te betrekken. In veel gevallen gaven de respondenten aan dat ons voorstel al door hen in de praktijk werd gebracht en er al zoiets bestond als een third space, bijvoorbeeld in de vorm van een TTI.

\subsection{FINANCIERING VAN WETENSCHAPPELIJK ONDERZOEK}

Een actuele beleidsvraag is in hoeverre publieke gelden voor onderzoek moeten worden verdeeld via de eerste geldstroom - via universiteiten - dan wel via de tweede geldstroom, via vooral NWO. Hierbij zijn drie soorten financiering te onderscheiden: themagericht onderzoek, persoonsgerichte subsidies en subsidiëring van voorstellen van wetenschappers. 


\section{Programmatische sturing}

In hoeverre moeten maatschappelijke behoeften een rol spelen bij de inrichting en bevordering van wetenschappelijk onderzoek? Enerzijds is het legitiem om brede maatschappelijke prioriteitsgebieden aan te wijzen, zoals energie, milieu, water, gezondheidszorg en vergrijzing. Anderzijds leidt het formuleren van programma's of projecten waarvoor wetenschappers of bedrijven vervolgens een voorstel in kunnen dienen ook tot vragen. Waarom zouden opdrachtgevers het beter weten dan wetenschappers? Bovendien bestaat het gevaar dat de 'waan van de dag' de richting van het onderzoek bepaalt. Ideeën moeten de kans krijgen om van onderaf op te borrelen uit bronnen van verscheidenheid. Dit betekent bijvoorbeeld ook dat ideeën voor promotieonderzoek in Nederland meer afkomstig moeten zijn van de promovendi zelf, in plaats van hun promotoren, zoals in de vs en op sommige universiteiten in Nederland reeds het geval is. Dit moet in de praktijk heel goed mogelijk zijn zonder dat de samenhang tussen de verschillende projecten verloren gaat.

De raad pleit derhalve voor het waarderen en aanboren van verspreide, lokale, diverse kennis in plaats van programmatische sturing van bovenaf.

\section{Prijzen en subsidies}

Zoals gesteld zijn er goede argumenten voor het toekennen van prijzen op basis van bewezen individuele excellentie uit de tweede geldstroom. Daarnaast is het nodig dat projecten kunnen worden gefinancierd op basis van de kwaliteit van een onderzoeksvoorstel, zodat nieuwkomers en buitenstaanders ook een kans krijgen. Dit is echter problematischer, omdat het moeilijk is om het succes en de waarde van exploratief onderzoek van tevoren in te schatten.

Een argument dat men hanteert voor financiering via NWO is dat er langs die lijn meer competitie is dan in toekenning binnen universitaire faculteiten of onderzoekscholen. Dat is tot op zekere hoogte het geval, maar ook onderzoekscholen geven tegenwoordig meer voorrang aan beloftevolle onderzoekers en projecten. De eigen intrinsieke ambities van de school spelen daarbij een stimulerende rol, maar ook de toenemende druk van concurrentie met andere scholen en periodieke beoordelingen in peer reviews door visitatiecommissies zetten hen daartoe aan. Oordelen verspreid over universiteiten bieden meer diversiteit van oordeel om tegemoet te komen aan diversiteit van denken.

Een tweede overweging slaat terug op de onvoorspelbaarheid van goed exploratieonderzoek. Nwo hanteert enerzijds het criterium van haalbaarheid, anderzijds het criterium van vernieuwing. Het eerste is eerder vooraf aan te tonen dan het tweede. Dit kan leiden tot een systematisch voordeel van haalbaarheid boven vernieuwing. Dit is een voorbeeld van hoe exploitatie exploratie kan verdringen. Lokaal, in een onderzoekschool, heeft men rijkere informatie en kennis over project, onderzoeker, begeleiding en andere omstandigheden en kan men veel beter de voortgang van het onderzoek volgen en bijsturen, wat bij Nwo nauwelijks gebeurt. 


\section{Beloningen}

Beloning achteraf heeft het voordeel dat het tegemoetkomt aan het probleem van de onvoorspelbaarheid van exploratief onderzoek. Het is daarom een goed idee een dergelijk systeem van expost-beloning ook in te stellen voor succesvolle initiatieven voor het opzetten van projecten op basis van eerstegeldstroommiddelen, of nieuwe door universiteiten in te zetten middelen. Ook dit is gebaseerd op een bottom-up-benadering waar generatie, toekenning, uitvoering en begeleiding van projecten zo laag mogelijk gelegd worden, bij de bron. Beloning in de vorm van nieuwe fondsen gebeurt dan op basis van prestaties in de vorm van publicaties, citaten, andere vormen van wetenschappelijke erkenning, octrooien, nieuwe bedrijven, en eventueel enquêtering bij bedrijven. Individuele onderzoekers, het liefst uit verschillende landen, zetten samen een project op en weten een van hun universiteiten over te halen om dit te financieren uit de eerste geldstroom. Wanneer het project een succes blijkt te zijn, krijgt de universiteit een beloning om het onderzoek voort te zetten of uit te breiden, of om nieuwe projecten te entameren.

\section{Interdisciplinair onderzoek}

Een laatste punt betreft het interdisciplinaire karakter van universitair onderzoek. Er zijn goede redenen om in onderzoek een disciplinaire focus te hanteren, maar feit is dat radicale vernieuwingen en de toepassing van nieuwe ideeën zich meestal voordoen in een discipline overschrijdende omgeving. Universiteiten zijn echter meestal gericht op en georganiseerd rondom afzonderlijke disciplines. Dit is een van de problemen in de samenwerking tussen bedrijfsleven en universiteiten. Het stimuleren van interdisciplinair onderzoek is immers een belangrijke reden voor het opzetten van een dergelijke samenwerking, wellicht in de vorm van een third space. Er zijn naar het oordeel van de raad maatregelen nodig om interdisciplinair onderzoek te stimuleren, bijvoorbeeld door middel van speciale programma's bij NWO of KNAW. Ook zijn maatregelen nodig waarmee interdisciplinair onderzoek op universiteiten wordt erkend en beloond in het kader van beoordelingssystemen en promoties.

\section{$5 \cdot 3$ CONCLUSIE}

Bedrijfsleven en academische wereld hebben vormen van interactie ontwikkeld die enerzijds zijn gericht op toepassingen (exploitatie) en anderzijds een inspiratiebron vormen voor wetenschappelijk onderzoek (exploratie). Er is echter ruimte voor verbetering, verdere ontwikkeling en uitwisseling van mogelijkheden en vormen. De overheid speelt hierbij een rol op de achtergrond door ervoor te zorgen dat er voldoende prikkels zijn voor universitaire medewerkers om deel te nemen aan deze interactie met het bedrijfsleven en ervaringen uit te wisselen in diverse vormen van samenwerking. Deze stimuleringsmaatregelen zijn geschikt voor grote bedrijven en voor kleine bedrijven met voldoende absorptiecapaciteit, zoals hightechbedrijven en spin-offs van universiteiten of grote bedrijven. De beperkte absorptiecapaciteit van veel bedrijven in het mkb maakt hogescholen voor hen tot een geschiktere samenwerkingspartner dan universiteiten. ${ }^{2}$ 
Om deze rol goed te kunnen vervullen, is het belangrijk dat hogescholen middelen krijgen voor toegepast onderzoek.

Met betrekking tot de financiering van wetenschappelijk onderzoek in het kader van innovatiebeleid, wordt hier gepleit voor het waarderen en aanboren van verspreide, lokale, diverse kennis. Tevens gelden hier de principes van opening voor uitdagers, opening voor samenwerking met andersdenkenden (in interdisciplinair onderzoek), en opening voor verassing en onzekerheid van innovatie, door meer nadruk te leggen op vernieuwing dan voorheen. 


\section{NOTEN}

$1 \quad$ Het gaat hier om de druk van concurrentie in productmarkten, en commercialisatie van wetenschappelijke kennis in die markten. Het gaat hier niet om concurrentie om onderzoeksgelden en reputatie tussen wetenschappers binnen universiteiten, die in principe goed is.

2 In Nederland wordt hierop ingespeeld middels het RAAK-programma, dat wordt gesubsidieerd door het ministerie van Onderwijs en uitgevoerd door Stichting Innovatie Alliantie. 


\section{ONDERNEMERSCHAP EN INNOVATIE}

Ondernemerschap is van groot belang voor innovatie en uiteindelijk voor economische groei. Wij definiëren ondernemerschap als het introduceren van nieuwe economische activiteiten door een individu dat leidt tot een verandering in de markt. In dit hoofdstuk bespreken we de relevante mechanismen hiervoor (6.1). Eerder is al geconstateerd dat er in Nederland een tekort aan ondernemerschap is. In dit hoofdstuk lichten we dit nader toe. Ondernemerschap is niet gemakkelijk in eenduidige cijfers te vatten: we zullen dan ook diverse indicatoren bekijken om een goed beeld te krijgen (6.2). Nadat we hebben aangetoond waar het tekort aan ondernemerschap een belemmering is voor de innovatiecapaciteit van Nederland, bespreken we de mogelijke oorzaken. Op basis van deze diagnose worden suggesties voor beleid geformuleerd (6.3).

\subsection{ONDERNEMERSCHAP, INNOVATIE EN ECONOMISCHE GROEI}

Ondernemerschap is een belangrijke bron van variatie in de economie. Ondernemers experimenteren met nieuwe combinaties van bestaande inzichten en materialen, die leiden tot verbeterde producten of tot geheel nieuwe producten. Nieuwe ondernemingen vervullen een belangrijke rol in het bevorderen van de concurrentie in bestaande markten. De experimenten van nieuwe ondernemingen kunnen leiden tot een proces van 'creatieve destructie', waarbij ondernemingen nieuwe producten introduceren en daarmee andere bestaande, minder goede of overbodige producten (en hun producenten) kunnen 'vernietigen'.

\section{Mislukkingen en succes}

Vele experimenten mislukken. Van tevoren is het niet mogelijk te voorspellen welke experimenten succesvol zullen zijn vanwege de onzekerheid over de technische haalbaarheid van het product, de mogelijkheden om een passende waardeketen te creëren, de adoptie door consumenten en de reactie van mogelijke concurrenten. Maar zonder ondernemerschap zouden, naast de vele mislukte experimenten, ook de uiteindelijk succesvolle experimenten de markt nooit bereikt hebben. De kennis om deze experimenten op te zetten is vaak zeer persoonsgebonden. Deze personen spelen een cruciale rol in het doorontwikkelen en commercialiseren van inventies. Zij zijn aanvankelijk werkzaam in onderzoekscentra, waar het experimenteren plaatsvindt, en besluiten een eigen onderneming op te richten zodra zij kansen ruiken voor een succesvolle marktintroductie van hun product. Experimenten kunnen vaker beter buiten bestaande onderzoeksorganisaties verder ontwikkeld worden tot een product, omdat bestaande organisaties in eerste instantie geen prikkel hebben om hier in te investeren, of omdat de ondernemer liever voor eigen rekening en risico deze kennis wil commercialiseren. 


\section{Kennisinstellingen en ondernemerschap}

Potentiële ondernemers die bij publieke instellingen werken, hebben vanwege de not-for-profit-oriëntatie van deze organisaties nog een extra reden om deze innovaties in hun eigen onderneming te exploiteren. De zogenoemde Knowledge Spillover Theory of Entrepreneurship ziet mede om die reden investeringen in publieke en private kennis als een belangrijke bron voor ondernemerschap en economische groei. Deze kennisinvesteringen zorgen voor een expansie van op nieuwe kennis gebaseerde kansen voor ondernemers. Als ondernemers deze kennis op een succesvolle wijze weten te commercialiseren, zal dit uiteindelijk ook leiden tot economische groei. Dergelijk op nieuwe kennis gebaseerd ondernemerschap kan zelfs tot 'creatieve constructie' leiden. In dat geval ontwikkelen ondernemers geheel nieuwe producten in de slipstream van hun innovaties, welke voorzien in behoeftes die voorheen niet werden herkend of vervuld (bijvoorbeeld het ontwikkelen van botvervangers door nieuwe biotechnologiebedrijven).

\section{Kleine en grote bedrijven}

Soms wordt gedacht dat kleine bedrijven de motoren zijn van de economie. Dit is slechts een halve waarheid. De meeste waarde wordt gecreëerd door de combinatie van kleine en grote ondernemingen in een onderlinge 'dynamische complementariteit'. Kleine ondernemingen zijn zeer nuttig voor exploratie: op kleine schaal kan met relatief lage kosten en met grote aantallen potentiële innovaties worden geëxperimenteerd. Daar waar bestaande grote organisaties hun producten en winsten in gevaar zien komen, kunnen nieuwe snelgroeiende ondernemingen vlot nieuwe producten op de markt zetten (en uiteindelijk ook een grote gevestigde onderneming worden). Als grote ondernemingen eenmaal de incentives hebben om deze nieuwe producten te commercialiseren, kunnen ze overgaan tot massaproductie en door middel van hun distributiekanalen en marketinginspanningen zorgen voor grootschalige verspreiding van het nieuwe product. Op hun beurt zijn kleine ondernemingen met hun experimenteercapaciteit vervolgens nuttig voor de verdere exploitatie van weer een nieuw product. Na de introductie van een product blijken er immers vaak allerlei nieuwe toepassingen en afzetgebieden ontwikkeld te kunnen worden. Grote ondernemingen zijn hier vaak blind voor of hebben daar geen interesse voor.

\section{Economische groei}

Ondernemerschap kan tot economische groei leiden doordat werknemers zelfstandig ondernemer worden en met hun nieuwe ondernemingen kansen uitproberen en realiseren die bestaande organisaties laten liggen. Deze nieuwe ondernemingen zorgen ook voor meer concurrentie ('uitdagers'), waardoor minder efficiënte gevestigde bedrijven zich moeten verbeteren of de markt moeten verlaten. Nieuwe ondernemingen die in staat zijn om te groeien zijn van groot belang: zij zijn in staat om efficiënt te produceren, nieuwe producten grootschalig in de markt te zetten en vormen zo een echte bedreiging voor bestaande partijen. 


\subsection{ONDERNEMERSCHAP IN NEDERLAND}

In het kader van innovatiebeleid is een belangrijke vraag of er 'genoeg' ondernemerschap is. Er is geen 'gouden standaard' of optimale hoeveelheid ondernemerschap die als richtlijn gebruikt kan worden. De analyse voor het beantwoorden van deze vraag begint bij een vergelijking van ondernemerschap over de tijd en in internationaal perspectief, alsook bij het vaststellen van de kwaliteit van het ondernemerschap. Op deze manier kan worden achterhaald of er sprake is van een tekort aan ondernemerschap in Nederland.

\section{Innovatief ondernemerschap}

Helaas is er geen indicator die één op één aangeeft hoeveel ondernemerschap zoals eerder gedefinieerd - er aanwezig is in Nederland. Noodgedwongen moeten we het dus met indicatoren doen die bij benadering weergeven hoe het met ondernemerschap gesteld is. Nederland scoort internationaal gezien qua aantallen zelfstandigen buitengewoon hoog. Het aantal nieuwe ondernemingen ligt internationaal gezien boven modaal en is in de afgelopen decennia spectaculair gestegen. Het lijkt erop dat de deregulering en de flexibilisering van de arbeidsmarkt in de laatste twee decennia een positief effect op deze groei hebben gehad.

Deze groei heeft echter weinig met innovatie te maken. Er zijn voornamelijk meer nieuwe bedrijven opgericht in de bouw en de dienstensector, en er is ook een sterke toename geweest van filialen van bestaande ondernemingen. Relatief veel zelfstandigen (zonder personeel) hebben voor een eigen bedrijf gekozen vanwege fiscale of persoonlijke redenen. Als er naar meer specifieke indicatoren

Figuur 6.1 Internationale vergelijking snelgroeiende ondernemingen

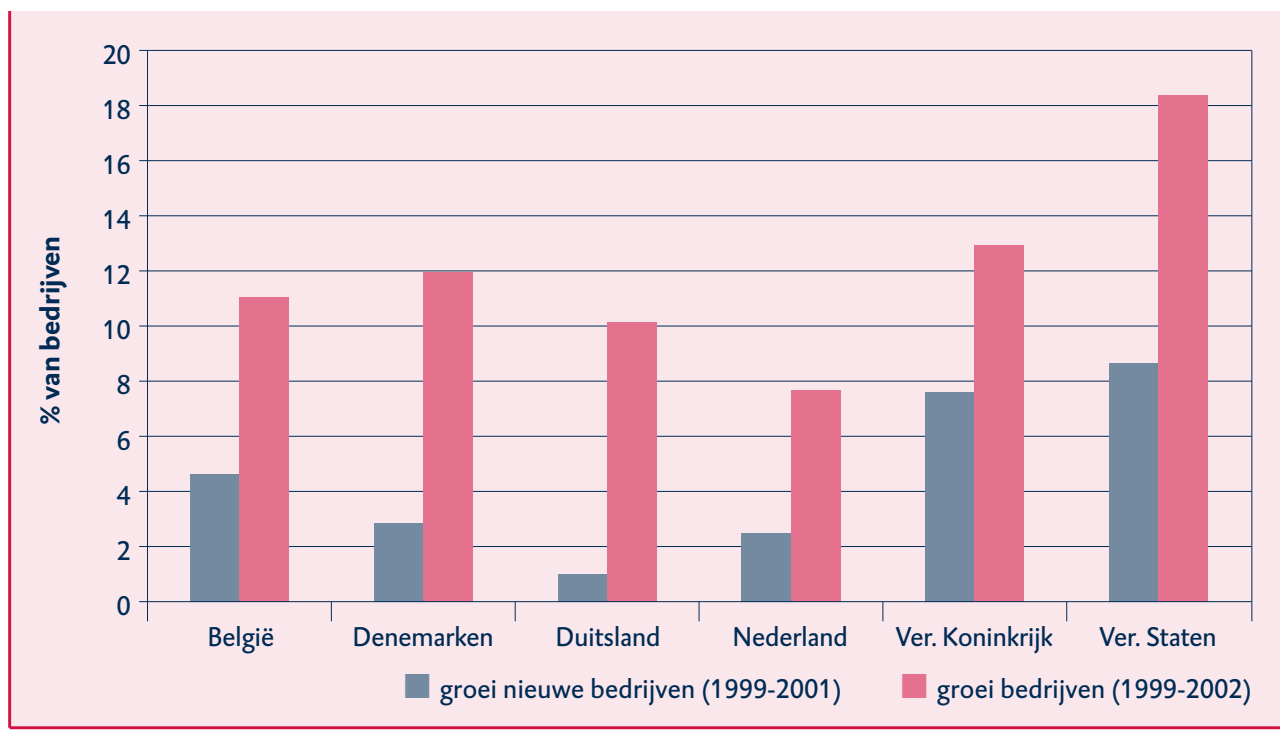

Bronnen: Hoffman and Junge 2006; EIM 2006 
wordt gekeken, zoals ambitieus ondernemerschap, de groei van (nieuwe) ondernemingen (zie figuur 6.1) en innovatie bij het mkb (zie figuur 2.3), dan scoort Nederland internationaal onder het gemiddelde en is er sprake van stagnatie. Naarmate de indicatoren ondernemerschap en innovatie beter weergeven, lijkt de positie van Nederland minder rooskleurig. Nederland loopt achter qua groei van nieuwe bedrijven en innovativiteit van kleine bedrijven.

Wat zijn de noodzakelijke voorwaarden voor ondernemerschap, en in welke mate kan hier een verklaring gevonden voor het tekort aan ondernemerschap in Nederland?

\section{Kansen voor ondernemerschap}

Een eerste voorwaarde voor ondernemerschap is dat er voldoende kansen liggen. Is er sprake van een tekort aan kansen voor ondernemerschap in Nederland? Recent onderzoek (Bosma en Schutjens 2008) heeft aangetoond dat de volwassen bevolking van Nederland ten opzichte van andere landen veel meer kansen ziet voor ondernemerschap. Ook is bekend dat de publieke en private onderzoeksinstellingen in Nederland qua kennisproductie niet achterlopen bij vergelijkbare andere landen, en dat er in Nederland door toegenomen deregulering (of reregulering) meer kansen voor ondernemerschap zijn gecreëerd. In algemene zin lijkt er dus geen sprake van een tekort aan kansen te zijn. Een veelgehoorde klacht bij beleidsmakers is zelfs dat wetenschappelijke kennis te weinig wordt geëxploiteerd.

\section{Ambitie}

Een tweede randvoorwaarde is dat er voldoende bereidheid en vaardigheid is om op nieuwe kansen in te spelen. Internationaal vergelijkend onderzoek laat zien dat de volwassen bevolking in Nederland qua kennis en vaardigheden voor ondernemerschap niet achterloopt (Bosma en Schutjens 2008). De enorme groei van het aantal nieuwe ondernemingen lijkt dit ook te bevestigen. Maar qua bereidheid om op nieuwe kansen in te spelen, vooral wat betreft de ambities om deze op grote schaal te vermarkten, loopt Nederland achter op vergelijkbare landen. Dit wordt ook weerspiegeld in de achterstand van Nederland op het gebied van jonge snelgroeiende ondernemingen. Dit gebrek aan ambities is moeilijk op korte termijn op te heffen. Alleen door middel van rolmodellen (positieve aandacht voor ondernemers van snelgroeiende ondernemingen) en het verhogen van aspiratieniveaus in het onderwijssysteem (het opheffen van de 'zesjescultuur') kan hier op langere termijn verandering in aangebracht worden.

\section{Onzekerheid}

De derde voorwaarde voor ondernemerschap ligt op het vlak van risicoacceptatie en onzekerheid. De Nederlandse bevolking lijkt niet te lijden onder een bovenmatige onzekerheid met betrekking tot het opzetten en groeien van ondernemingen. In tegenstelling tot de veelgehoorde klacht dat het stigma op falen in Nederland zeer hoog is, blijkt uit internationale vergelijkingen (Stam 20o8) dat de angst om te falen - in internationaal opzicht - relatief weinig Nederlanders ervan weer- 


\begin{abstract}
houdt om een onderneming op te zetten. Wel kan onzekerheid een verklaring vormen voor het kleine aantal technologische ondernemingen in Nederland. Het opzetten en groeien van technologische ondernemingen brengt bovenmatig veel onzekerheden met zich mee, met name vanwege de nog niet bestaande vraag naar het te ontwikkelen product. De overheid kan hier een belangrijke rol spelen als leading customer. Op het gebied van public procurement heeft Nederland een achterstand (Porter et al. 2007). De overheid zou zich meer kunnen manifesteren als leidende klant van startende innoverende ondernemingen in publieke sectoren, zoals defensie, zorg, energie en milieu. Een belangrijke doelstelling hierbij moet zijn dat in de praktijk niet alleen gevestigde grote bedrijven de overheid bereiken, maar dat juist ook uitdagers, nieuwe en kleine bedrijven, hieraan deelnemen. De specifieke invulling van dit voorstel is samengevat in box 6.1.
\end{abstract}

\title{
Box 6.1 De overheid als afnemer van innovatie
}

De overheid kan als motor van innovatie fungeren door zelf als inkopende marktpartij op te treden. Daartoe moeten overheidsinstellingen vooraf duidelijk, eenvoudig en regelmatig aangeven in welke technologische gebieden zij graag projecten zouden willen initiëren, zodat kleine en nieuwe bedrijven hier gemakkelijk op kunnen inspringen. Vervolgens zouden de overheidsinstellingen in drie fasen de ontwikkeling hiervan kunnen aanbesteden.

In eerste instantie zouden de vernieuwendheid en haalbaarheid van ideeën moeten kunnen worden uitgewerkt voor relatief kleine bedragen, voor relatief veel indieners. Op deze manier kunnen ondernemingen ideeën uitwerken waar normaal gesproken geen financiering voor is - de zogenaamde finance gap (te veel voor een banklening, te weinig voor een venture capital investering). In de tweede fase krijgt een selectie van de indieners uit de eerste fase de mogelijkheid om nieuwe technologieën en producten te ontwikkelen. Dit geringere aantal projecten vereist meer financiering per project dan in de voorgaande ronde. Als vervolgens de projecten een dusdanig 'levensvatbaar' niveau hebben bereikt na deze tweede fase zijn ze rijp om opgenomen te worden in reguliere opdrachten voor overheidsinstellingen.

Deze fasering verlaagt de risico's voor de overheid en garandeert een grote mate van initiële variëteit in ideeën. De aanbesteding moet in de vorm van contracten worden uitgevoerd, niet in de vorm van leningen of subsidies, zodat de vraag van overheidsinstellingen enigszins geïdentificeerd en vervuld kan worden. Het feit dat de overheid zaken doet met deze ondernemingen kan ook voor investeerders en andere klanten een reden zijn om met deze nog kleine onderneming in zee te gaan. Ten slotte moet de onderneming het intellectuele eigendom van de opgedane kennis krijgen, zodat zij ook de incentives heeft om in deze procedures deel te nemen. Om de kans te vergroten dat dit uiteindelijk gerealiseerd wordt moet de doelgroep duidelijk afgebakend worden (bijvoorbeeld een maximale omvang van 100 werknemers) en moeten er sancties zijn op het niet besteden van een van tevoren vastgesteld deel van het budget (bijvoorbeeld 2,5\%, dat wordt afgenomen van de desbetreffende instelling als het niet besteed is aan kleine bedrijven).

In de Verenigde Staten is een dergelijke regeling al meer dan 20 jaar succesvol: de zogenaamde Small Business Innovation Research (SBIR) regeling heeft een belangrijke rol gehad in de opkomst en groei van zeer innovatieve bedrijven (Lerner 1999). 


\section{De organisatie van exploitatie}

Ten vierde is een noodzakelijke voorwaarde dat er een geschikte organisatorische setting moet zijn voor nieuwe ondernemingen om kansen te exploiteren. Een veelgenoemd argument van marktfalen betreft de onderinvestering in nieuwe kennis, omdat de opbrengsten van het op de markt brengen van producten die hieruit voortkomen niet altijd door het innoverende bedrijf kunnen worden toegeëigend. Een oplossing hiervoor is een goed werkend systeem van intellectueel eigendom. Dit systeem lijkt goed te werken in Nederland en Europa, met als kanttekening dat het vaak nog grote barrières heeft voor kleine bedrijven. Het aanvragen en in stand houden van een octrooi is relatief duur voor kleine bedrijven en de toekenning duurt vaak te lang voor diezelfde kleine bedrijven. Een andere reden dat de organisatie van een onderneming en het op de markt zetten van een nieuw product niet gerealiseerd worden is een gebrek aan investeringskapitaal. Nederland loopt internationaal gezien vooral achter op het gebied van durfkapitaal voor jonge bedrijven (zie figuur 2.3) en informele investeerders (Stam 2008). De Nederlandse overheid zorgt momenteel op diverse manieren voor een vergroting van het aanbod van venture capital (Technopartner, uitdagerskrediet).

\section{Investeringen in innovatie}

Een vijfde voorwaarde betreft het creatieve vermogen van bedrijven om nieuwe combinaties van bestaande kennis en materialen te realiseren die tot innovatie leiden. Zoals al eerder is gememoreerd, toont internationaal vergelijkend onderzoek aan dat het Nederlandse mkb minder investeert in innovatie dan het Europese gemiddelde (zie figuur 2.3). Dit lijkt niet veroorzaakt te worden door een gebrek aan opleidingsniveau of kapitaal maar door een gebrek aan ambities.

De bovengenoemde factoren overziende is de conclusie dat de achterstand op het gebied van ondernemerschap in Nederland vooral veroorzaakt lijkt te worden door een gebrek aan ambitie - wat leidt tot te weinig investeringen in innovatie en in groei - en in mindere mate door enkele belemmeringen in het innovatiesysteem, zoals een gebrek aan investeringskapitaal en geavanceerde vraag.

\subsection{TOEKOMSTIG BELEID}

Voor toekomstig beleid is het van belang om naar trends in de samenleving te kijken, zodat beleidsmakers daar rekening mee kunnen houden in hun planvorming. De verwachting is dat globalisering, de groei van kennis en technologische verandering trends zijn die in betekenis zullen toenemen. Dit betekent dat de internationalisering van het innovatiesysteem zal toenemen (internationalisering van consumptie, productie en zelfs specifieke taken/banen). Ook zal de zoektocht naar nieuwe kennis meer buiten de grenzen van de onderneming en het land plaatsvinden. Bovendien zal de toepassing van nieuwe technologieën hoog op de agenda blijven staan. 


\section{Bevordering van spin-offs en corporate venturing}

Technologische vernieuwing is in eerste instantie meestal een taak voor grote organisaties. De toepassing van nieuwe technologie is en blijft echter een taak van spin-offs van deze ondernemingen. Een middel om dit in de toekomst te vereenvoudigen is het verbieden van het zogenoemde anticoncurrentiebeding. Dit beding vormt een onnodige barrière voor potentiële ondernemers om nieuwe toepassingen van bestaande kennis te realiseren (Fallick et al. 2006). De toepassing van nieuwe technologieën vindt vaak plaats door middel van nieuwe businessmodellen. Deze businessmodellen zouden zowel middels spin-offs als via corporate venturing vorm kunnen krijgen. Corporate venturing mislukt nog te vaak door organisationele problemen. Hier ligt in eerste instantie een taak voor de grote bedrijven, maar innovatiebeleid zou hier aan kunnen bijdragen door best practices op dit gebied onder de aandacht te brengen. Door spin-offs en corporate venturing worden bestaande ervaringen ingezet op nieuwe manieren, daarom zijn deze praktijken een goede context voor de combinatie van exploratie en exploitatie.

\section{Box 6.2 Spin-off}

Voorbeeld van een spin-offis 'Liquavista'. Dat bedrijf biedt een vernieuwde vorm van LCD (Liquid Crystal Displays) die ambiënt licht gebruikt in plaats van licht op basis van voeding uit een batterij. Dat geeft een helderder beeld, ook in zonlicht, en gebruikt minder energie uit de batterij. Dat is van belang voor mobiele telefoons en andere apparaten met een display, zoals horloges. De technologie werd in een periode van tien jaar ontwikkeld binnen Philips, maar vormde de basis van een spin-off, in 2006, in samenwerking tussen Philips en venture capitalist New Venture Partners. Het bedrijf is gestart op de Philips 'campus' in Eindhoven, en heeft inmiddels ook vestigingen in Cambridge (vK) en Hongkong.

Bron: www.liquavista.com

\section{Interactie tussen kennisinstellingen en bedrijfsleven}

Voor de benutting van nieuwe kennis moet de interactie tussen kennisinstellingen en (nieuwe) bedrijven hoog op de beleidsagenda blijven staan. In het kader van ondernemerschap kent deze interactie vele vormen: van samenwerking tussen mkb en kennisinstellingen tot scholing van talent dat later zelf een onderneming begint of bij het mkb gaat werken en als alumnus een relatie onderhoudt met de kennisinstelling. Eerder gaven we aan dat kennisintensieve respectievelijk door technologie gedreven kleine bedrijven wel aansluiting kunnen vinden bij universiteiten, maar dat de meerderheid van het mkb daar niet de benodigde absorptiecapaciteit voor heeft en het eerder moet zoeken bij het hbo. In het vorige hoofdstuk hebben we opgemerkt dat het gevaar bestaat van te veel commerciële invloed op universiteiten. Daarom stelden we voor om een zogenoemde third space te creëren tussen bedrijfsleven en universiteit. Dit heeft ook gevolgen voor incubators bij universiteiten. Privatisering van incubators om de groei van veelbelovende spin-offs van universiteiten beter te stimuleren en ondersteunen heeft twee voordelen ten opzichte van de huidige publieke incubators: deze organisa- 
ties krijgen de beschikking over vakkundiger en marktgerichter personeel en de rol van de universiteit als producent van publieke kennis blijft gewaarborgd.

\section{Internationaal ondernemerschap}

Transnationale ondernemers kunnen als belangrijke makelaar van kennis fungeren tussen diverse (nationale) innovatiesystemen. Veranderingen in de informele en formele instituties met betrekking tot migratie zou een belangrijk middel kunnen zijn om de connecties van Nederlandse emigrantenondernemers met Nederland te versterken en de ambities en internationale connecties van immigrantenondernemers en remigranten te benutten. Toenemende internationale mobiliteit van arbeid, en ondernemers in het bijzonder, is in zulke omstandigheden geen bedreiging maar een kans voor een verbetering van de innovatiecapaciteit van Nederland.

\subsection{CONCLUSIE}

In dit hoofdstuk is het belang van ondernemerschap voor de nationale innovatiecapaciteit besproken. Nederland heeft relatief weinig ambitieuze ondernemers en innovatieve kleine bedrijven. Het laatste is ook nog eens afgenomen in de laatste jaren. Toch lijken er weinig beperkingen te zijn voor ondernemerschap in Nederland, qua kansen, kennis en vaardigheden en stigma op falen. Er is wel relatief weinig investeringskapitaal en er lijken onnodige toetredingsbarrières te zijn voor nieuwe technologische bedrijven. Uiteindelijk is het van belang om te onderkennen dat een verhoging van het ambitieniveau (voor groei en innovatie) de belangrijkste sleutel is tot een verbetering van ondernemerschap in Nederland. Pas als dit is gerealiseerd zullen aanvullende maatregelen, bijvoorbeeld met betrekking tot financiering en stimulering van de vraag, effectief worden. 


\section{ORGANISATIE EN INNOVATIE}

De onderlinge verbindingen en wisselwerkingen tussen de elementen van het innovatiesysteem zijn van groot belang. Dat is een kwestie van organisatie: tussen mensen binnen organisaties en tussen organisaties. De groeiende aandacht voor vraagstukken van organisatie, als onderdeel van het bredere begrip 'sociale innovatie', is in lijn met de geconstateerde toename van aandacht voor niet-technologische aspecten van innovatie, dat wil zeggen aspecten naast wetenschap en technologie. Ook al is het onduidelijk of het innovatietekort in Nederland te wijten is aan grotere tekortkomingen in organisatie dan elders, dat er gemiste kansen zijn is wel zeker. Net zoals er behoefte is aan opening voor innoverende uitdagers in de vorm van zelfstandig ondernemers, is er ook binnen bedrijven behoefte aan opening voor interne innovatie. Eerder wezen we op het belang voor bedrijven en andere organisaties om zich te bekwamen in de kunst van samenwerking, op basis van een wijs gebruik van vertrouwen. Dat komt hierna nog terug bij de bespreking van netwerken. Hier richten wij ons op interne organisatie, vooral van bedrijven. Het gaat in dit hoofdstuk om organisatie voor innovatie (7.1) en om innovatie van organisatie (7.2). Tevens werpen we een eerste blik op organisatie bij de overheid (7.3). Innovatie van organisatie is voor een belangrijk deel gebaseerd op nieuwe mogelijkheden van ICT, vooral internet. In hoofdstuk 1 werd geconstateerd dat Nederland ten opzichte van de vs en een aantal EU-landen achterblijft in de ontwikkeling van productiviteit, vooral in diensten. Dit is voor een deel, mogelijk een groot deel, te wijten is aan achterlopen in het gebruik van die mogelijkheden (zie ook Van Ark en De Jong 2004; McKinsey 2007).

\subsection{ORGANISATIE VOOR INNOVATIE}

In hoofdstuk 4 werd de basislogica aangegeven van hoe exploitatie en exploratie op elkaar kunnen bouwen. Na een ontdekking verschuift de aandacht stap voor stap van exploratie naar exploitatie en na consolidatie van een innovatie kan een nieuw pad van exploratie betreden worden, waar stap voor stap meer afstand genomen wordt van de gevestigde praktijk van exploitatie. Op enig moment is er in die zin tegelijk exploitatie en exploratie, waarbij echter het ene afneemt ten gunste van het andere. Het probleem is dat vroege stadia van exploratie en gevorderde stadia van exploitatie moeilijk op eenzelfde plaats en tijdstip te combineren zijn, omdat ze verschillende en zelfs contraire eisen stellen aan mentaliteit, werkwijze en organisatie. Exploitatie berust op een gevestigde taakverdeling, standaards, praktijken en betekenissen, terwijl exploratie juist gaat om het verbreken daarvan. Het eerste biedt aangrijpingspunten voor kansberekening, redelijk volledige contracten, beoordeling en controle het tweede niet. Het eerste biedt resultaat op korte termijn, het tweede resultaat op lange termijn. Daarom krijgt onder druk het eerste voorrang en het tweede niet. Sluiting dreigt opening uit te sluiten. Het is daarom vaak onafwendbaar om exploitatie en exploratie te scheiden in tijd of plaats. Het is dan wel nodig om die vervolgens op elkaar aan te laten sluiten. 


\section{Scheiding in tijd}

In scheiding van tijd richt men zich op een periode van het ene, waarna men stap voor stap overschakelt op het andere. Men herziet daarbij de structuur, werkwijze, competenties, mentaliteit en de dragers daarvan in een soort fluctuerende organisatie. Die periodieke herstructurering brengt onzekerheid met zich mee en vergt grote flexibiliteit van management en medewerkers. De duur van een cyclus varieert met de aard van de desbetreffende technologie en markt: in de dienstensector is de cyclus vaak korter dan in de industrie. Een probleem bij herstructurering van exploratie naar exploitatie en weer terug is dat die niet werkt als men tegelijkertijd producten of activiteiten heeft in verschillende stadia van de cyclus.

\section{Scheiding in plaats}

De andere optie is scheiding in plaats, waarbij een output van exploratie wordt overgedragen aan exploitatie. Een klassiek voorbeeld is de scheiding tussen R\&D en productie. Het probleem ligt dan in de koppeling tussen de twee. Een mogelijke oplossing daarvoor is roulatie van personeel tussen beide. Een andere optie is het formeren van een soort matrix met een basisstructuur van operationele afdelingen (exploitatie) waarin men doorsneden maakt voor ontwikkelingsprojecten. Nog een andere oplossing is een externe scheiding aanbrengen, waarbij het ene bedrijf zich richt op de exploratie en het andere op de exploitatie. Activiteiten worden dan overgedragen van exploratie naar exploitatie wanneer die er rijp voor zijn. Dit is een van de argumenten voor het opkomende idee van 'open innovatie', in de zin van innovatie door samenwerking. Een voorbeeld is de samenwerking tussen kleine biotechnologiebedrijven die nieuwe werkzame stoffen of processen ontdekken en ontwikkelen (exploratie), en grote farmaceutische bedrijven die de resultaten omzetten in productontwikkeling, testen, en efficiënte productie en marketing (exploitatie) (Gilsing 2005). Het probleem ligt dan toch weer in de aansluiting tussen de twee. Voor een voorbeeld van een poging om dat binnen een organisatie tot stand te brengen, zie tekstbox 7.1. Voor verdere voorbeelden, zie Nooteboom en Went (2008).

\section{Box 7.1 Centraal Boekhuis}

Centraal Boekhuis koopt en levert boeken voor de boekhandel. Het bedrijf heeft drie afdelingen, die nauw op elkaar moeten aansluiten.

(1) 'Assortimentsvorming' van boeken van velerlei uitgevers, met een grote mate van differentiatie van pakketten voor verschillende boekwinkels, naar samenstelling en omvang.

(2) 'Logistiek' voor snelle, efficiënte en betrouwbare levering.

(3) ' $\mathrm{IT}^{\mathrm{T}}$ om de logistiek te ondersteunen en om strategisch vitale informatie te vergaren en te analyseren omtrent welke boeken goed lopen, over welke onderwerpen en van welke schrijvers, en tegen welke prijs, met welke lezers op welke plaats, ten behoeve van de afdeling Assortimentsvorming en als dienstverlening aan uitgevers en boekwinkels.

Efficiënte exploitatie is duidelijk cruciaal en van overwegend belang, als primaire voorwaarde voor overleving. Maar niet alleen exploitatie, ook exploratie is van belang, om ontwikkelingen in lees- en 
koopgedrag, in de uitgeverij en in technologie van ICT (internet!), en de samenhang daartussen, bij te houden en waar mogelijk te voorzien. Vanwege de samenhang tussen de drie kernactiviteiten moet innovatie in de drie afdelingen afgestemd en gesynchroniseerd worden. Om dit te realiseren en tegelijkertijd een efficiënte exploitatie te handhaven, werd de volgende oplossing gevonden. Voor exploratie werd een permanent R\&D-team ingesteld van acht mensen vanuit de drie verschillende afdelingen die op verschillende momenten worden aangesteld (twee nieuwe deelnemers elk half jaar) en na twee jaar weer uittreden. Ze keren dan echter niet automatisch terug naar hun oude afdeling en ze weten van tevoren niet naar welke afdeling ze gaan.

Men kan de voordelen zien. Een is dat exploratie is geworteld in ervaring in exploitatie en wordt verricht vanuit het bewustzijn dat men later operationele verantwoordelijkheid krijgt voor de implementatie. De verschillende afdelingen zijn vertegenwoordigd om de samenhang tussen de kernactiviteiten te bewaken. Er is doorstroming in het team om cognitieve afstand te onderhouden, maar er is ook continuïteit in het team, omdat elk half jaar twee nieuwe leden gaan samenwerken met vier zittende leden. Omdat ze niet weten of ze terugkeren naar hun oude afdeling, hebben ze niet de neiging om in de exploratie hun achterban uit de wind te houden.

Geeft dit ook problemen? Het systeem roept vragen op. De veronderstelling lijkt dat de cyclus van innovatie twee jaar is, maar wat gebeurt er als die cyclus langer duurt, zodat men niet kan afmaken waar men aan begon? Zijn er steeds mensen te vinden die geschikt en gemotiveerd zijn voor zowel exploratie als exploitatie? Veroorzaakt het periodiek mensen weghalen uit de afdelingen niet voor discontinuïteit die dan weer de exploitatie verstoort? Worden rivaliteiten tussen afdelingen wellicht in de exploratie voortgezet, ondanks het feit dat men waarschijnlijk niet terugkeert naar de oude afdeling? Is het systeem bestand tegen radicale verandering zoals het bestellen van boeken via internet? Dit illustreert dat in het vraagstuk van exploitatie en exploratie elke oplossing zijn problemen heeft, en hoe hardnekkig het probleem daardoor is.

Het is van groot belang dat vooral het bedrijfsleven leert dergelijke vormen van organisatie voor de combinatie van exploratie en exploitatie te gebruiken en verder te ontwikkelen. Onderdeel van het innovatiebeleid van de overheid kan zijn dat te bevorderen, met bewustwording en bevordering van de verspreiding en uitwisseling van ervaringen.

Onlangs hebben onderzoekers, vakbonden, werkgeversorganisaties en beleidsmakers het Nederlands Centrum voor Sociale Innovatie opgericht, dat zich richt op het verbeteren van de organisatorische voorwaarden voor innovatie. Dit is een goed initiatief. Wij vrezen echter dat ook hier de aandacht vooral uitgaat naar verbeteringen ten behoeve van exploitatie, in de vorm van verbeteringen in het kader van 'operationele excellentie', waarbij men aan exploratie niet meer toekomt. Er zijn ook initiatieven nodig om exploratie te bevorderen, die wat verder van de dagelijkse bedrijfspraktijk af staan. In elk geval moet men oppassen dat maatregelen voor exploitatie niet de exploratie in de weg gaan zitten.

In kleinere bedrijven zijn exploitatie en exploratie vaak gemakkelijker te combineren. Exploitatie- en exploratiemedewerkers opereren op dezelfde werkvloer, schakelen zo nu en dan van het ene op het andere over, terwijl de ondernemer er zelf bovenop zit (zie tekstbox 7.2). 
De отв ('Only The Best') groep in Eindhoven werkt met 150 werknemers aan diverse geavanceerde toepassingen van nieuwe technologie, onder andere in lichtgevende, buigzame polymeerpanelen, energie-efficiënte en goedkope straatverlichting, een nieuw substraat en depositietechniek voor zonnecellen, plus een volautomatische productiestraat daarvoor, en systemen voor duurzame energie in woningen. Ron Kok, de bestuursvoorzitter, leidde ons over de werkvloer. Op onze vraag waar de exploitatie respectievelijk de exploratie plaatsvond, wees hij naar twee groepen die naast elkaar werkten in een gezamenlijke open ruimte. Die plaagden elkaar met hun verschillende competenties, werkwijzen, belangstelling en ervaring, maar ze onderbraken waar nodig hun werk om elkaars mening te vragen. Ron Kok praatte hier zowel als daar, liep rond en zag een probleem van discrepantie of wrijving zodra die zich voordeed en nam direct iedereen mee voor een overleg om de problemen op te lossen.

Dit is ongetwijfeld een van de oorzaken voor het relatief grote innovatieve vermogen van kleinere bedrijven (Acs en Audretsch 2003). Een zekere formalisering van planning, organisatie en rapportage kan waarde hebben voor kleine bedrijven om aandacht te krijgen voor strategisch vooruitzien en financiële planning, en om de veelal stilzwijgende kennis enigszins vast te leggen. Daarin schuilt echter ook een gevaar: te veel formalisering werpt blokkades op voor de flexibiliteit en vloeibaarheid, en zelfs enige gewenste ambiguïteit van taken en activiteiten en vooral de schakelingen en koppelingen tussen exploitatie en exploratie.

Een vorm van organisatie voor innovatie is ook het bevorderen en faciliteren door grote bedrijven, van spin-offs van bedrijven door werknemers die op eigen houtje een vinding, die binnen het moederbedrijf niet als passend gezien wordt, willen omzetten in innovatie in external corporate venturing. Deze belangrijke bron van innovatie is hiervoor reeds besproken (hoofdstuk 6).

\section{Innovatie en arbeid}

De verkenning bij dit rapport geeft een overzicht van onderzoek in de toegepaste psychologie omtrent de organisatorische condities voor creatieve teams (Anderson en Gasteiger 2008). Het blijkt dat die vaak sterk lijken op, zo ze niet hetzelfde zijn als, voorwaarden voor de kwaliteit van arbeid: intrinsieke motivatie, autonomie, opening en psychologische veiligheid en inspirerend leiderschap. Hier lijkt een kans te liggen voor een nieuw verbond tussen management en personeel en tussen werkgevers en werknemers. Hier bestaat de mogelijkheid niet alleen innovatie te bevorderen, maar ook de kwaliteit van arbeid. De raad is van mening dat het vanuit die optiek een gemiste kans is dat er geen werknemersvertegenwoordigers zijn opgenomen in het Innovatieplatform. Nu bestaat dit orgaan alleen uit politici, zakenmensen, enkele wetenschappers en een paar ondernemers.

Eerder al is gewezen op het belang van opening ten aanzien van het verloop van innovatieprojecten, om ruimte te laten voor verrassing. Om innovatietrajecten open te houden voor verrassing kunnen subsidie- en beloningssystemen nut 
afwerpen. Men moet daarbij de subsidie of beloning niet zozeer baseren op de beoogde inhoudelijke uitkomst, maar op prestaties ongeacht de inhoud van de uitkomst, zoals in onderzoek aantallen publicaties van goed niveau, octrooien, en oordelen van peers. Daarnaast kan men zich richten op intrinsieke motivatie en reputatie. Mensen, vooral in wetenschap en de toepassing ervan, hebben eer en voldoening in succes hoog in het vaandel. Succes is afgezien van directe beloning goed voor hun carrière, en bevorderlijk voor hun reputatie, en dat werkt vooral goed als middelen voor verdere projecten mede op basis van reputatie worden toegekend.

Verder is beargumenteerd dat toezicht en controle innovatie in de weg kunnen zitten. Dat lijkt vooral van toepassing te zijn op de overheid. Sinds de jaren tachtig van de vorige eeuw zijn overheden in navolging van de private sector meer aandacht gaan besteden aan de meting en evaluatie van prestaties, in results based management als onderdeel van new public management. In 2002 werd dat ingevoerd onder de naam 'Van Beleidsbegroting tot Beleidsverantwoording' (VBTB). Dit was gericht op transparantie voor het parlement en ontwikkelde zich tot een instrument voor een meer efficiënte overheid (Tweede Kamer 2004; Van der Dussen 2006). Dat is ongetwijfeld legitiem en van grote waarde. Het heeft echter ook, vooral voor innovatie, een negatieve kant omdat men vooraf zekerheid verlangt over de uitkomst.

\subsection{INNOVATIE VAN ORGANISATIE}

Met betrekking tot de combinatie van exploratie en exploitatie, maar ook breder, is dankzij de nieuwe mogelijkheden van ICT, met name van internet, een aantal nieuwe vormen van 'platformorganisatie' ontstaan. Gebruikers kunnen hun producten hier in meer of mindere mate vormgeven of zelfs bijdragen aan de innovatie ervan. Daarnaast ontstaan open source-gemeenschappen, waarin de gebruikers tevens producent zijn.

In platformorganisaties bieden producenten een platform met modules waaruit gebruikers hun eigen goed of dienst kunnen configureren, vragen kunnen indienen, of informatie kunnen aanbieden. In termen van de cyclus van ontdekking (hoofdstuk 3) biedt dit een platform voor de differentiatie van producten. Er zijn ook platforms voor uitbesteding, waar potentiële toeleveranciers behoeften kunnen identificeren en analyseren en aanbiedingen kunnen doen. Zoals is aangegeven door Von Hippel (2005) gaan sommige producenten verder door het bieden van toolkits voor ontwikkeling, die aan gebruikers middelen geven voor productontwerp, het maken van prototypes en het toetsen ervan. Bijvoorbeeld: software voor gebruikers om hun eigen 'chips' (microprocessoren) te ontwerpen. In termen van de cyclus van innovatie biedt dit een basis voor 'reciprocatie', in verkenningen van nieuwe combinaties, met nieuwe elementen vanuit de eigenzinnige gebruikscontext van de klant. 
Open source communities gaan nog een stap verder: hierin zijn er geen aparte producenten meer, maar zijn de gebruikers hun eigen producenten. Gebruikers produceren voortdurend nieuwe toevoegingen aan het bestaande systeem met vrije toegang tot de bron (source). Dit doet zich vooral voor in de productie van niet-fysieke producten, zoals software (bijvoorbeeld Linux, Apache, Sendmail) en informatie (bijvoorbeeld Wikipedia). Deze vorm van innovatief organiseren is zo succesvol, omdat men voluit gebruik kan maken van het potentieel van internet en niets meer nodig heeft dan dat (bijvoorbeeld geen fysieke distributie).

Dergelijke nieuwe vormen van organisatie zijn minder goed werkbaar in de industrie vanwege de fysieke productie. Toepassing is vooral voor de hand liggend in de dienstverlening, omdat daar van nature al de gebruiker coproducent is (een patiënt, bijvoorbeeld, participeert in het proces van behandeling). Dat impliceert dat met name bij de overheid en semi-overheid kansen liggen, omdat het daar vaak gaat om dienstverlening aan burgers. Er zijn al verrassend veel innovaties van deze soort in publieke diensten (zie tekstbox 7.3). Dit staat in contrast met de veelgehoorde opvatting dat innovatie bij overheidsdiensten nauwelijks voorkomt en ook niet goed mogelijk is.

\section{Box 7.3 Het Britse ‘Direct Gov' project}

Een voorbeeld van innovatie van overheidsdiensten is het Britse 'Direct Gov' project. Dit is een portfolio van faciliteiten en diensten (centraal webportaal, kiosk, digitaal tv-kanaal) bedoeld om online overheidsdiensten meer efficiënt en effectief aan te bieden. Het is ontworpen als centraal referentiepunt voor burgers voor online toegang tot kerndiensten van de overheid. In plaats van een organisatie te kiezen die is geschoeid op de leest van ministeries, is het project bedoeld om toegang te geven naar onderwerp (zoals autogebruik) of groep (zoals invaliden). Volgens de Cabinet Office is dit de grootste e-transformatie in het Verenigd Koninkrijk (NAO 2006).

\subsection{INNOVATIE VAN OVERHEIDSDIENSTEN}

Platformorganisaties en misschien zelfs open source-gemeenschappen bieden juist bij overheidsdiensten kansen voor meer innovatie van zowel kwaliteit als snelheid.

Tot op zekere hoogte is het nuttig om hier het gebruikelijke onderscheid te hanteren tussen innovaties voor efficiëntie en innovaties voor kwaliteit. Een vraag is dan wel wat de betekenis is van kwaliteit in publieke diensten. Kwaliteit omvat daar niet alleen aspecten van gebruikersnut zoals relevantie, gebruiksgemak, gemak van toegang en snelheid van reactie, maar ook publieke kwaliteit zoals gelijkheid van toegang, rechtvaardigheid (due process), en publieke verantwoording.

Voor een beter inzicht in innovatieprocessen bij de overheid kijken we eerst naar hoe die in het bedrijfsleven verlopen. Het is nuttig daarbij gebruik te maken van het bekende onderscheid tussen frontoffice (in contact met klanten) en backoffice 
(achterliggende productie en ondersteuning). In het bedrijfsleven zijn vroege innovaties voornamelijk gericht op efficiëntieverbetering op basis van technologie, vooral IT. Innovaties komen daar tot stand onder druk van het bestuur om kosten te reduceren en het rendement van bestaande uitgaven te verhogen. De meeste op efficiëntie gerichte innovaties zijn door de backoffice geïnitieerd en niet zelden aan de frontoffice opgelegd. Zij berusten op schaalvergroting, verdere specialisatie en arbeidsdeling, standaardisatie van procedures, het opleggen van nieuwe technologie, uitbesteding en het benutten van mogelijkheden van synergie tussen activiteiten ('scope'). Latere innovaties, die niet zozeer de efficiëntie maar eerder de gebruikskwaliteit willen bevorderen, komen vooral voort vanuit de vraag. Zij zijn gericht op de kans en noodzaak nieuwe diensten te introduceren en snellere respons te bieden, op betere locaties en in meer gedifferentieerde en voor gebruikers gemakkelijker vormen. Daarbij is de frontoffice onmisbaar als kanaal van informatie van klanten naar bedrijf. Er ontstaat druk van de frontoffice, als die de kans krijgt en gemotiveerd wordt, voor nieuwe producten of processen. Maar dat moet dan wel door de backoffice gelegitimeerd, geaccepteerd en ondersteund worden.

Bij publieke diensten kan men verwachten dat er vanwege publieke en politieke verantwoording veel meer angst is voor falende innovaties. Verantwoording is strak georganiseerd en initiatieven komen van 'bovenaf', omdat het de politiek is die beleid maakt en omdat er vanwege overwegingen van rechtvaardigheid en gelijkheid minder ruimte is voor selectie en differentiatie van markten. Dan is de ruimte voor initiatieven vanuit de frontoffice al snel erg klein en daarmee is de ruimte voor productinnovatie beperkt. Men kan verwachten dat het merendeel van de innovaties geïnitieerd wordt vanuit de backoffice en meer gericht is op efficiëntie dan op kwaliteit. Er zijn indicaties dat dit inderdaad het geval is en dat de processen erg top-down zijn, met veel nadruk op hiërarchie en rang (zie NAO 2006 en box 7.4). ${ }^{1}$ Dit is moeilijk te rijmen met het principe dat innovatie in kwaliteit vanuit de vraag ruimte vereist voor de frontoffice, die vrijwel altijd lager is in hiërarchie en rang en minder goed is gepositioneerd in beleidsnetwerken.

\section{Box 7.4}

Innovaties in de publieke sector

\footnotetext{
In Nederland is in opdracht van de Commissie Innovatie Openbaar Bestuur onderzoek gedaan naar innovatie in de publieke sector, met een vergelijking tussen openbaar bestuur, politie en defensie, onderwijs en cultuur en zorg en welzijn (InAxis 2004). Dat geeft een goede illustratie van hoe schaars radicale innovatie is: 10 procent van het totaal. Van alle praktijkvoorbeelden heeft 50 procent een direct effect op burgers. Waar in het openbaar bestuur de meeste praktijkverbeteringen op instigatie van het management tot stand komen (top-down), zijn het in de zorg, en meer nog bij de politie, de medewerkers die de innovatie initiëren. Onderwijs staat in alle indicatoren onderaan. Waar in de periode 2002-2004 in het geheel van de publieke sector het aandeel van radicale innovaties met vier procentpunten toenam (tot 10\%), bleef het in het onderwijs constant (5\%). Inspiratie vanuit de interne organisatie komt in de publieke sector gemiddeld in $45 \%$ van de gevallen voor (in het onderwijs 14\%).
} 
Een kanttekening: dit zijn slechts globale indicaties en de vergelijking tussen onderdelen van de publieke sector kan misleidend zijn. Het is mogelijk dat in sommige sectoren innovaties minder door de meting zijn opgepakt dan in andere.

Nader onderzoek naar vormen, omvang en oorzaken van innovatie in de publieke sector is nodig. Het punt hier is dat innovatie ook in de publieke sector mogelijk gebeurt en voor uitbreiding vatbaar is.

Gewezen is al op de gevaren voor innovatie van strakke beheersing, in procedures van 'accountability'. Dat is echter niet het enige en wellicht ook niet het belangrijkste probleem. Gerelateerd daaraan zijn de genoemde organisationele en mentale obstakels om innovatie te openen naar initiatieven van lager ingeschaalde staf met een lagere status en positie en naar deelname van burgers die meer mee gaan doen in de frontoffice.

Bij overheidsdiensten is een perspectiefverandering nodig met betrekking tot de rol van de frontoffice bij het initiëren en leiden van innovatie en bij het verder openen van de frontoffice voor burgers. Dat is een noodzakelijke voorwaarde om te kunnen profiteren van het enorme, nog onbenutte potentieel van nieuwe organisatievormen zoals van de platformorganisatie. Als onderdeel van het platform moeten er dan ook modules zijn die toegespitst zijn op verschillende behoeften en competenties van verschillende burgers, om gelijkheid van toegang te waarborgen. 


\section{NOOT}

1

NAO (2006) laat zien dat ongeveer tweeënhalf keer zo veel innovaties gericht zijn op efficiëntie als op kwaliteit. Het rapport laat ook zien dat ambtenaren vaak te voorzichtig zijn voor innovatie en dat hun invloed op de dienstverlening in recente jaren is versmald tot de levering van de dienst en interne organisationele vraagstukken eerder dan de inhoud en kwaliteit van de dienst. 


\section{NETWERKEN EN REGIONAAL BELEID}

De voor een innovatiesysteem zo belangrijke verbindingen tussen schakels nemen veelal de vorm aan van netwerken, met name tussen bedrijven en andere organisaties. De structuur, aard en sterkte van die netwerken hebben een belangrijke invloed op innovatie. Het is de vraag in hoeverre overheidsbeleid langs die weg, dus via invloed op structuur, aard en sterkte van verbindingen, gevolgen heeft voor het innovatieproces (8.1). Netwerken concentreren zich vaak in regionale 'clusters' en innovatiesystemen. Dat roept vragen op met betrekking tot lokale inbedding en agglomeratie (8.2). Bij elkaar hebben die implicaties voor een regionaal innovatiebeleid (8.3).

\subsection{NETWERKEN}

Eerder is al gewezen op de noodzaak van open innovatie, in de zin dat bedrijven niet alles zelf proberen te doen maar samenwerking zoeken. Daarbij is het belang aangegeven van verschillen in kennis die groot genoeg zijn om een potentieel van schumpeteriaanse nieuwe combinaties te bieden, van complementaire kennis, vaardigheden en competenties (Meeus en Faber 2006), maar niet zo groot dat onderling begrip en samenwerking om dat potentieel te realiseren onmogelijk zijn ('optimale cognitieve afstand').

\section{Corporate governance}

Wetenschappelijk onderzoek terzake geeft aan dat bedrijven te veel fuseren en overnemen en dat dit vaak geen waarde toevoegt (zie o.a. Schenk 2005). Men streeft er te veel naar om eigendom en zeggenschap te krijgen of te behouden als doel op zich (om 'de baas' de zijn), in plaats van te kiezen voor de (moeilijker) weg van samenwerking in wederzijdse afhankelijkheid, wat vaak beter zou zijn voor innovatie. Samenwerking tussen organisaties in allianties bewaart en benut cognitieve afstand, biedt meer flexibiliteit in het (re)configureren van activiteiten, wat ook van belang is voor nieuwe combinaties en geeft minder kosten en problemen van integratie in een enkele onderneming. Dit geldt vooral voor complementaire activiteiten in verschillende technologieën, producten of markten. In het geval van meer gelijke activiteiten en met een focus op efficiëntie eerder dan innovatie, zijn er betere argumenten voor integratie door fusies en overnames. In een empirisch onderzoek lieten Bleeke en Ernst (1991) zien dat waar in het algemeen zowel fusies/overnames als allianties op hun best in 50 procent van de gevallen succesvol zijn (waarde toevoegen), het hanteren van de vuistregel van fusies/overnames in het geval van gelijke producten in gelijke markten en allianties in alle andere gevallen voor beide het succespercentage stijgt van 50 procent tot 70 procent. Het verdient aanbeveling om in beleid ten aanzien van corporate governance meer nadrukkelijk de vraag te betrekken wanneer fusies en overnames een slechtere optie zijn dan allianties en hoe bevorderd kan worden dat de beste optie gekozen wordt. 


\section{Dichtheid van netwerken}

Samenwerking (en rivaliteit) vindt plaats in netwerken. In de sociologische en bedrijfskundige literatuur heeft een debat gewoed over strength of weak ties (Granovetter 1973; Burt 1992) versus strength of strong ties (Coleman 1988). Dichte en sterke verbindingen zijn slecht voor de toegang tot nieuwe bronnen van informatie, voor flexibiliteit van configuratie en voor toe- en uittreding tot netwerken, en juist die zijn nodig voor innovatie. Dichte en sterke verbindingen zijn echter goed voor risicospreiding in contacten, voor gezamenlijke absorptiecapaciteit en voor de beheersing van risico's in relaties, op basis van reputatiemechanismen, coalitievorming en het bouwen van vertrouwen. ${ }^{1}$ Dit leidt tot een gecompliceerde afweging die niet gemakkelijk is om te zetten in een simpele regel voor beleid, zeker niet voor de centrale overheid, op afstand van het specifieke veld van samenwerking waar het daadwerkelijk om gaat. Niettemin zijn er echter ook enkele meer algemene principes waarop wel beleid gevoerd of getoetst kan worden, zoals die van aantallen potentiële deelnemers, hun verscheidenheid, deelnemers met een centrale positie en het tot stand brengen van netwerken met een zogenaamde small world-structuur. Beleid dat gericht is op het bevorderen van ondernemerschap heeft bijvoorbeeld een positieve invloed op het aantal en de verscheidenheid van mogelijke deelnemers in netwerken.

\section{Small worlds}

Small world-netwerken zijn netwerken die lokaal een grote dichtheid hebben met sterke verbindingen, die echter worden gecombineerd met minder dichte en zwakkere verbindingen met andere, vergelijkbaar gestructureerde netwerken elders op afstand. Dit geeft een generieke oplossing van het eerdergenoemde vraagstuk van de beste combinatie van strong en weak ties. Lokaal heeft men hiermee een goede basis voor samenwerking en gezamenlijk vermogen om kennis van elders te absorberen, terwijl cognitieve afstand en flexibiliteit worden ingebracht door de zwakkere, meer flexibele verbindingen met bronnen elders (zie tekstbox 8.1 en Bathelt et al. 2004).

\section{Box 8.1}

\section{Small worlds in de Nederlandse biotechnologie}

Gilsing en Nooteboom (2006) geven empirische evidentie van het innovatieve potentieel van small worlds in een analyse van de netwerkstructuur van lokale Nederlandse clusters van biotechnologiebedrijven en universiteiten, in samenhang met de netwerkstructuur van hun verbindingen met vergelijkbare buitenlandse clusters. De lokale netwerken hebben een hoge dichtheid van sterke verbindingen in termen van duur van relaties, frequentie van contact en specifieke investeringen in de relatie. Dat versterkt het vertrouwen en onderling begrip, wat het benutten van cognitieve afstand bevordert. Het versterkt ook de gezamenlijke absorptiecapaciteit. Het heeft echter het nadeel van te weinig flexibiliteit van configuraties en een dreiging van te weinig diversiteit van kennis en een te grote vermindering van cognitieve afstand. Dat wordt gecompenseerd door minder dichte en minder hechte relaties met vergelijkbare gemeenschappen elders, vooral in het buitenland, met meer flexibiliteit en cognitieve afstand. 
In hoofdstuk 4 werd aangegeven dat langdurige relaties kunnen leiden tot een te kleine cognitieve afstand, tenzij partijen ook putten uit andere bronnen die zij niet met elkaar delen. Een andere bron van voortdurende variëteit is voldoende toe- en uittreding van deelnemers. Deze overwegingen leveren elementen voor de ruimtelijke dimensie van innovatiebeleid (regionaal, nationaal en internationaal), die hieronder nader worden uitgewerkt.

In de werking van het principe van small worlds ligt een verband met de innovatiecyclus waar werd beweerd dat externe verbindingen met onbekende contexten of toepassingsgebieden nieuwe uitdagingen en kansen kunnen opleveren, nieuwe inzichten verschaffen in de beperkingen van bestaande manieren om dingen aan te pakken, druk geven tot verandering omdat bestaande oplossingen niet passen in die nieuwe context, indicaties bieden hoe nieuwe elementen kunnen worden ingebouwd en hoe oude en nieuwe elementen kunnen worden geïntegreerd in een nieuwe architectuur.

\subsection{REGIONALE INNOVATIESYSTEMEN}

Innovatieve netwerken concentreren zich vaak in geografische regio's, zoals Food Valley in Oost-Nederland en Maintenance Valley in West-Brabant. Dit biedt voordelen. Marshall (189o) liet al zien dat colocatie van gelijksoortige activiteiten kan leiden tot voordelen van gebundelde aantrekkingskracht voor afnemers, gebundelde vraag naar gespecialiseerde arbeid en toeleveranciers en uitwisseling van werknemers en ervaring. Colocatie van complementaire activiteiten geeft ook snelheid en efficiëntie van afstemming. Een ander voordeel is dat economische activiteiten die zijn ingebed in netwerken van regionale innovatiesystemen minder snel verdwijnen naar opkomende economieën (zoals China en India) dan geïsoleerde activiteiten of technologieën. Een nieuwer inzicht is dat colocatie van verschillende activiteiten, in bedrijvigheid en recreatie, in een local buzz, bijdraagt tot de benutting van diversiteit op basis van geplande en toevallige ontmoetingen, voor nieuwe combinaties (Bathelt et al. 2004). Lokale buzz draagt ook bij tot reputatiemechanismen en persoonlijke contacten en processen van voice die bijdragen aan het vertrouwen dat, zoals in hoofdstuk 3 beargumenteerd, vooral in innovatie van belang is (zie ook Storper en Venables 2004). Lokale tussenpersonen helpen in de formatie en begeleiding van samenwerking, het overbruggen van cognitieve afstand en het bouwen en onderhouden van vertrouwen.

\section{Gerelateerde variëteit}

In de recente geografische literatuur wordt het begrip 'gerelateerde variëteit' van activiteiten gehanteerd, dat wil zeggen activiteiten die weliswaar verschillen maar toch tamelijk op elkaar lijken en kansen bieden voor complementariteit. Door deze gerelateerde variëteit zou de regionale werkgelegenheid het sterkst groeien. Zowel bij meer variëteit als bij meer specialisatie neemt de groei af (zie Frenken et al. 2007). Hier wordt een verband zichtbaar tussen cognitieve afstand en gerelateerde variëteit: bij beide wordt gepleit voor verschillen die groot genoeg 
zijn voor mogelijke vernieuwing, maar niet zo groot dat dit potentieel niet kan worden benut.

\section{Kleine en grote bedrijven}

Vaak is aangetoond dat kleine en grote bedrijven elkaar aanvullen (zie hoofdstuk 6). Dat is iets waarmee in het regionaal beleid rekening gehouden moet worden. Kleine bedrijven zorgen ervoor dat er voldoende variëteit bestaat op het gebied van trial-and-error-leren, wat cruciaal is voor experimenten. Grote bedrijven bieden op hun beurt niet alleen een platform voor spin-offs van nieuwe ondernemingen, maar vormen ook een basis voor grootschalige exploitatie (productie, distributie) van innovaties en voor verregaande specialisatie van arbeid (met de bijbehorende gespecialiseerde vraag naar arbeid). Ook zijn grote bedrijven een interessante partij voor universiteiten, omdat zij meer gespecialiseerde kennis in huis hebben, lagere transactiekosten bieden en over meer financiële en andere middelen beschikken om een samenwerking aan te gaan op het gebied van exploratie, mogelijk in de vorm van een third space. Voor veel kleine bedrijven zijn hogescholen een meer natuurlijke partner, omdat de cognitieve afstand minder groot is.

\section{Rol van universiteiten}

Het gevaar bestaat dat innovatieactiviteiten opgesloten raken in regionale of lokale 'clusters' die geografisch en economisch geïsoleerd zijn en waarbij de verbindingen te sterk en dicht zijn. Het small world-concept stelt dat er ook 'kanalen' moeten zijn die een agglomeratie verbinden aan vergelijkbare, concurrerende en complementaire agglomeraties elders. Hierdoor ontstaat een 'open agglomeratie'. Op dit punt suggereren wij dat universiteiten wellicht de knooppunten van small world-netwerken kunnen vormen, die zorgen voor een verbinding tussen regionale innovatiesystemen en vergelijkbare systemen elders in de wereld. Universiteiten zijn ingesteld op contacten in internationale gemeenschappen.

Deze mogelijke rol van universiteiten moet worden gekoppeld aan het idee van een third space tussen universiteiten en het bedrijfsleven. Die verbindt universiteiten met het plaatselijke bedrijfsleven in regionale innovatiesystemen, terwijl de universiteiten de vereiste kanalen naar de buitenwereld bieden. Dit wordt geïllustreerd in het eerder aangegeven empirisch onderzoek van biotechnologie in box 8.1. Samenwerking op lokale schaal is dankzij de ervaring en de experimenten die voortkomen uit de lokale variëteit waarschijnlijk vooral geschikt om middels een interdisciplinaire structuur en opzet de mogelijkheden van nieuwe combinaties goed te benutten, terwijl de mondiale contacten van de universiteit met de buitenwereld verdieping en renovatie bieden op gespecialiseerde gebieden (Ponds en Van Oort 2006). Universiteiten als knooppunten, met een third space die de universiteiten koppelt aan het plaatselijke bedrijfsleven, kunnen bedrijven ook helpen om toegang te krijgen tot nieuwe input- en outputmarkten. Dat geldt met name voor middelgrote en kennisintensieve kleine bedrijven. Niet alleen universiteiten maar ook grote 
bedrijven kunnen echter de rol vervullen van 'kanaal' voor contacten met de buitenwereld.

Kortom, innovatie in regionale systemen wordt bevorderd door gerelateerde variëteit en door contacten met de buitenwereld en/of een wisseling in spelers: hierdoor blijft de variëteit behouden en de cognitieve afstand optimaal. Wellicht kunnen universiteiten, die per definitie zijn gericht op internationale contacten en uitwisseling een verbinding met de buitenwereld vormen. Dit kan aansluiten bij de contacten tussen universiteit en bedrijfsleven op het gebied van exploratie, zoals eerder uiteengezet. Wanneer er in de regio multinationals zijn gevestigd kunnen ook zij deze rol vervullen.

\subsection{REGIONAAL BELEID}

In het huidige regionale beleid, van nationale en regionale overheden, bestaat vooral veel aandacht voor best practices in regionale systemen elders. Daarbij kan worden gedacht aan Silicon Valley, industriële ‘districten' in Italië, Helsinki, Cambridgeshire (VK) en Boston. Beleidsmakers hopen systemen te kunnen overplanten naar de plaatselijke situatie. Dit is echter een illusie. In Italië zijn beroemde industriële gebieden ontstaan dankzij institutionele zwakheden, waardoor actoren op persoonlijke netwerken werden teruggeworpen. Beleidsmakers proberen nu de Italiaanse situatie te imiteren, terwijl de onderliggende zwakheid ontbreekt. Lokale en regionale systemen zijn historisch gegroeid door een samenloop van lokaal gebonden en uiterst padafhankelijke omstandigheden. De contextuele kenmerken van deze systemen zijn essentieel voor de structuur en de prestaties en kunnen niet worden gegeneraliseerd (Boschma 2005). Hun succes moet niet gezocht worden in blauwdrukken van specifieke configuraties met een pretentie van universele, context onafhankelijke geldigheid, maar in een onderliggende logica over hoe componenten en omstandigheden op elkaar ingrijpen. Op basis van dergelijk inzicht in de 'dieptestructuur' van de ruimtelijke dynamiek kan men proberen configuraties te ontwikkelen die aansluiten op specifieke omstandigheden en mogelijkheden. Er is een ruimtelijke verdeling van arbeid, waarbij sommige regio's uitblinken in onderzoek, andere in innovatie en weer andere in productie. Vaak zijn verschillende bedrijfstakken in verschillende regio's geconcentreerd en binnen één bepaalde bedrijfstak kan een bedrijf er op de ene plaats anders uitzien dan op de andere plaats. Dat betekent dat de verschillende regio's potentieel hebben ten aanzien van verschillende soorten activiteiten. Het is bijvoorbeeld kortzichtig om het beleid uitsluitend te richten op regio's waarin R\&D sterk vertegenwoordigd is, waarbij kansen op het gebied van toepassingen en productie uit het oog worden verloren. Bepaalde indicatoren, zoals $\mathrm{R} \& \mathrm{D}$, creatieve klasse, het aantal hightech- en kennisintensieve bedrijven geven aan wat de sterke punten van een regio zijn en in Nederland is vrijwel iedere regio wel sterk op het gebied van een of meer van deze indicatoren, zoals empirisch aangetoond door Raspe et al. (2004). 
In de uitvoering van het huidige sleutelgebiedenbeleid wordt in toenemende mate de samenwerking binnen regionale structuren sterk gestimuleerd. Het beleid raakt daarmee een ander beleid, 'Pieken in de Delta', dat zich richt op regionale clusters. Als in feite het sleutelgebiedenbeleid om goede redenen zo verweven raakt met Pieken in de Delta, verdient het overweging die twee te integreren in één enkel programma. In het huidige beleid zijn de innovatieprogramma's (i.c. sleutelgebieden) leidend ten opzichte van de gebiedsgerichte programma's (i.c. Pieken in de Delta). Dit impliceert dat, als voor de ontwikkeling van een regio ook versterking van fundamenteel onderzoek nodig is, dit alleen kan als het in een sleutelgebied past.

\section{Grotere rol voor regionale overheden}

Gezien de specificiteit van de plaatselijke en historische context en de systematische samenhang tussen elementen van het regionale innovatiesysteem (zoals ruimtelijke ordening, infrastructuur, de plaatselijke arbeidsmarkt en onderwijs) zou het regionale beleid moeten worden ontwikkeld door de plaatselijke of regionale overheid en niet door de nationale overheid. Wanneer dit inderdaad gebeurt, is er ook meer ruimte voor gedifferentieerde maatregelen voor verschillende vestigingen van grote bedrijven; nationaal beleid richt zich toch eerder op de totaliteit van een grote onderneming. Dit is in lijn met ons uitgangspunt van verspreide, gedifferentieerde, lokale kennis die men moet aanboren, eerder dan dat men van bovenaf ontwerpen maakt en oplegt.

Dit argument voor regionaal ingebed beleid wint aan kracht wanneer we kijken naar de dynamiek van clusters. Ook daar is sprake van een dynamiek van exploratie en exploitatie, met verschillende eisen in verschillende stadia. In de beginfase van ontwikkeling is een relatief grote behoefte aan lokale inbedding te verwachten met sterke en dichte verbindingen. Deze fase zal dan waarschijnlijk worden gevolgd door een stadium waarin deze inbedding iets minder sterk wordt, zodat het potentieel van nieuwe innovaties op markten iets verder van huis benut kan worden en men toegang krijgt tot nieuwe bronnen. Dit mechanisme dient zowel als aanvulling op de lokale variëteit als om de cognitieve afstand te herstellen. Dit levert nogal wat complicaties op bij een beleid dat is gericht op regionale clusters en innovatiesystemen. Zijn beleidsmakers in staat om vast te stellen in welk ontwikkelingsstadium een lokaal cluster zich bevindt en krijgen zij het voor elkaar om hun beleid tijdig in te voeren, voordat de volgende ontwikkelingsfase is bereikt waarin het beleid juist contraproductief kan werken? Het kan er dan op neerkomen dat het beleid inbedding stimuleert in een fase dat deze juist minder zou moeten worden. Regionale overheden zijn vaak beter op de hoogte van wat er speelt en kunnen sneller reageren dan de nationale overheid. Regionale of lokale overheden zijn aan de andere kant echter niet altijd in staat om lokale structuren te doorbreken, zodra deze contraproductief zijn geworden als gevolg van de creatieve destructie van radicale innovatie. Netwerken van ondernemers, arbeiders en politici die de eerdere welvaart mogelijk maakten, verstarren en staan verandering in de weg: 'institutionele lock-in' (Grabher 1993). 


\section{Beperkte rol van nationale overheid}

Gezien de lokale specificiteit van kennis, omstandigheden, successen en mislukkingen, en de noodzaak om op het juiste moment dat beleid te kiezen en te implementeren dat aansluit bij de verschillende ontwikkelingsstadia, zou de centrale overheid bescheiden moeten zijn ten aanzien van haar ambities voor het sturen van regionale ontwikkeling en dit beleid zo veel mogelijk over moeten laten aan regionale initiatieven van onderaf, die beter kunnen inspelen op de specifieke configuratie van betreffende variabelen. Bij deze variabelen gaat het onder andere om gerelateerde variëteit, complementariteit van kleine en grote bedrijven, samenwerking tussen universiteiten en grote bedrijven en tussen hogescholen en kleine bedrijven, spin-offs van bedrijven, kenmerken van netwerkstructuren, onderwijs en scholing, arbeidsmobiliteit, contacten buiten de regio (small worlds) en inkomende en uitgaande mensen en bedrijven in de regio. De nationale overheid zou zich dan kunnen richten op de contacten tussen regionale clusters en andere clusters in binnen- en buitenland, de mogelijke rol van universiteiten bij het tot stand brengen en onderhouden van contacten met het buitenland, het komen en gaan van organisaties, op maatregelen om lokale of regionale vriendjespolitiek of zelfs corruptie tegen te gaan. 


\section{NOOT}

1 Voor een overzicht van empirische evidentie voor deze effecten van netwerken, en een recente uitbreiding daarvan in een empirisch onderzoek van de combinatie van netwerkeffecten en het eerder besproken effect van cognitieve afstand, zie Gilsing et al. (2008). 


\section{CONCLUSIES}

Dit rapport hanteert een benadering die zich richt op hoe innovatie werkt op het niveau van actoren (mensen, organisaties, overheid) en hun interacties, in inventie, innovatie en diffusie van innovaties. De analyse van deze hoe-vraag leidt vervolgens naar de implicaties over wat er moet gebeuren op velerlei niveaus: voor werknemers, werkgevers, bedrijven, andere organisaties en de overheid. Dit hoofdstuk concentreert zich op de vraag waar de overheid op moet letten als het gaat om het stimuleren en faciliteren van initiatieven die innovatie tot stand brengen, dan wel het innovatief vermogen vergroten en hoe de overheid de prikkel tot innovatie kan versterken.

De analyse van dit rapport richt zich op de vraag welke richting het overheidsbeleid met betrekking tot innovatie moet ingaan om de innovatiecapaciteit van Nederland te verbeteren. Traditioneel zijn er in Nederland verschillende richtingen met betrekking tot innovatiebeleid: (a) generiek beleid ter versterking van marktwerking en (b) beleid gericht op specifieke actoren (bedrijven, individuen) of sectoren (bedrijfstakken, technologiegebieden). Dit rapport onderscheidt zich hiervan: het laat zien dat de overheid het innovatieproces kan faciliteren en stimuleren zonder zelf de inhoud te bepalen (dat wil zeggen, zonder zelf te kiezen voor het steunen van specifieke actoren en sectoren). Wij komen ook tot aanbevelingen die in doel generiek en in uitvoering specifiek zijn. Het opheffen of omzeilen van obstakels voor ondernemerschap of complexe projecten, bijvoorbeeld, is generiek, waarvoor principes zijn aan te wijzen, maar kan in zijn uitwerking in het ene geval een geheel andere invulling krijgen dan in het andere geval. Dat is nodig vanwege de inherente onzekerheid van innovatie waardoor men niet kan voorspellen in welke vorm obstakels zich voor zullen doen.

Hierna geven wij eerst een samenvatting van de betekenis en urgentie van innovatiebeleid en het achter het beleid liggende denken. Vervolgens reiken wij verscheidene aanbevelingen aan die een invulling bieden van de in dit rapport bepleite vier vormen van opening en van de benodigde combinatie van exploratie en exploitatie. In het huidige beleid is op velerlei punten goede voortgang geboekt. Onze aanbevelingen zijn voor een deel gericht op verdere verbetering langs de lijnen van het huidige beleid. Daarnaast geven wij aan hoe de overheid kan bijdragen aan een bredere aanpak van innovatie. Naast beleid gericht op wetenschap en technologie omvat dit ook beleid gericht op ondernemerschap, op het veranderen van organisatie, management en arbeid zodanig dat kennisproductie breder plaatsvindt en nieuwe kennis sneller wordt herkend, verspreid en aangewend voor nieuwe producten en diensten. Aandacht wordt besteed aan hoe de overheid kan bijdragen aan de creatie van netwerken en allianties tussen organisaties ten behoeve van innovatie. Ten slotte is er aandacht voor mogelijke knelpunten. De aanbevelingen zijn mede gericht op kennelijke en mogelijke knelpunten die eerder in dit rapport zijn geïdentificeerd: institutionele belemmeringen, het vraagstuk van valorisatie, bronnen en obstakels voor ondernemerschap, knel- 
punten en mogelijkheden in interne organisatie en externe organisatie en het vraagstuk van criteria voor keuzen voor de inzet van middelen.

\subsection{URGENTIE VAN INNOVATIEBELEID}

\section{Matige innovatieprestaties van Nederland}

Innovatie is de belangrijkste bron van verdere welvaartsgroei, vooral nu bij de huidige daling van het aandeel van de werkzame bevolking de toename van het aantal werkenden als bron wegvalt. Innovatie is ook nodig om verschuivingen in werkgelegenheid op te vangen bij toenemende concurrentie van opkomende economieën. De arbeidsproductiviteit geldt als indicator voor de mate waarin een economie innovatief is. Nederland neemt wat de productiviteitsontwikkeling in EU-lidstaten betreft een middelmatige positie in, dit in schril contrast met het bbp per hoofd waar ons land hoog scoort. Een en ander duidt erop dat de (interne) verandering van ons bedrijfsleven, maar ook van onze nationale economie, trager verloopt dan de veranderingen in de voor ons zo belangrijke omgeving. Voor een open economie als de Nederlandse die zo afhankelijk is van ontwikkelingen in die omgeving is dit zorgelijk. Er zijn vele aanwijzingen uit onderzoeken dat dit vooral toe te schrijven is aan een gebrek aan 'valorisatie' (overdracht en toepassing van kennis) en een tekort aan ondernemerschap. Gebrek aan valorisatie komt onder andere tot uiting in een lagere dan gemiddelde prestatie in nieuwe productiemethoden en producten in zowel industrie als dienstverlening.

Daar komt bij dat gemiddeld genomen het mkb het laatste decennium eerder minder dan meer innovatief is geworden. Het percentage innovatieve mkbondernemingen ligt op de meeste indicatoren ver onder het EU-gemiddelde. Diffusie van innovaties vergt goed onderwijs en ook daar is verbetering nodig, niet alleen in het technisch-wetenschappelijk onderwijs, maar ook in andere disciplines en in het algemeen vormend en het beroepsonderwijs op alle niveaus. Er zijn ook, zij het zwakkere, indicaties dat er tekortkomingen zijn in de organisatie van (strategische) samenwerking, binnen en tussen organisaties, consumenten en burgers, maar ook tussen werkgevers en werknemers. De conclusie lijkt onontkoombaar dat juist op het moment dat innovatie van groot belang is, mede gezien het open karakter van onze economie, de prestatie van Nederland matig is.

De implicatie is dat het opnieuw doordenken van het innovatiebeleid urgentie heeft. Het is van belang dat (nog eens) te constateren. Uit ervaring lijkt de aandacht voor innovatie de kop op te steken wanneer het economisch slecht gaat. Het ging slecht bij de instelling van het Innovatieplatform in 2003. Het gevaar is niet denkbeeldig dat de aandacht verslapt wanneer het economisch beter gaat. Er is alle reden voor om de aandacht voor innovatie vast te houden.

\section{Instituties, institutionele context en voorwaardenscheppend beleid}

Macro-economische condities zijn voor het creëren van optimale condities voor innovatie van groot belang. Die condities zijn noodzakelijk maar niet voldoende voor innovatie. Detailkennis is nodig van de processen die daadwerkelijk kunnen 
leiden tot de ontwikkeling van exploratie en exploitatie. Een kernpunt is dat een voortgaande dynamiek van uitvinding, innovatie en diffusie van innovaties, in een voortdurend op elkaar bouwen van ontwikkeling (exploratie) en toepassing (exploitatie), niet een simpele kwestie is van marktwerking die vanzelf tot stand komt als men er maar 'ruimte voor de markt' geeft. Een beperking wordt gevormd door het feit dat de responsiviteit van het bedrijfsleven op marktprikkels sterk wordt bepaald door organisatie-interne factoren, waarbij weerstanden tegen veranderingen en de daarmee verbonden organisatie-inertie mede verklaren waarom innovatie te weinig tot stand komt. Maar er zijn meer problemen. Het is niet zo dat markten automatisch werken als men maar beperkingen oplegt aan gedrag dat marktwerking 'verstoort'. De gedachte dat men slechts obstakels op moet heffen is te simpel. Sommige obstakels zijn niet op te heffen of moeten niet opgeheven worden, zoals bestaande standaards en regels die nodig zijn voor efficiënte werking van bestaande markten. Als ze innovatie en nieuwe markten in de weg zitten, moet men ze omzeilen en daartoe paden creëren. Markten zijn goed voor selectie op (statische) efficiëntie, maar niet altijd voor de creatie van diversiteit. Druk van concurrentie kan ook een prikkel geven tot het ontwijken van prijsconcurrentie door middel van productdifferentiatie waardoor de veronderstelde efficiëntie van marktwerking gedeeltelijk teniet gedaan wordt. Concurrentie kan ook de ruimte wegnemen, in tijd en middelen, die nodig is voor exploratie van nieuwe betekenissen en mogelijkheden.

Markten vergen instituties en creëren instituties die op zich nieuwe markten in de weg kunnen zitten. Zij zijn onderdeel van een innovatiesysteem, met een coevolutie van markten en instituties. Instituties zijn nodig, niet alleen voor het opheffen van obstakels, maar ook als enablers. Voor een voortgaande dynamiek van exploitatie en exploratie is een enabling state nodig, een overheid die condities schept voor creatie en behoud van diversiteit, voor instituties en markten die zowel selecteren alsook ruimte laten en paden bieden voor verandering van de selectieomgeving en voor de diffusie van innovaties, het scheppen van netwerken en daarmee uiteindelijk het verbeteren van de randvoorwaarden en mogelijkheden voor concurrentievermogen en productiviteitsgroei.

Langetermijneffecten van de vormgeving van de institutionele context en de daarmee samenhangende regelgeving gericht op het behalen en behouden van innovatief voordeel blijken echter even belangrijk te zijn als de meer traditionele aspecten van regelgeving zoals het verminderen van onzekerheid door processen van standaardisering, het minimaliseren van negatieve kortetermijneffecten op bijvoorbeeld de werkgelegenheid en het (achteraf) verhelpen van sociale noden. Tot het op de institutionele context gerichte overheidsoptreden dat ondernemers, bedrijven en organisaties prikkelt tot het innovatief gedrag behoren een rijke omgeving van veelgeschakeerd onderwijs- en scholingsaanbod, het vooraf investeren in menselijk en sociaal kapitaal, maar ook activerend arbeidsmarktbeleid, het verhogen van de betrokkenheid van personeel in ondernemingen, arbeidstijden en voorzieningen die combinatie van arbeid, zorg en gezin mogelijk maken. Over de mogelijke vormgeving en noodzakelijke aanpassingen van de 
verzorgingsstaat, alsmede over de in het licht van die wijzigingen noodzakelijke flexibilisering van de arbeidsmarkt, de overgangen van baan- naar werkzekerheid en over de verhoging van de arbeidsparticipatie heeft de WRR eerder adviezen uitgebracht (WRR 2006b; WRR 2007). Deze vormen het complement van het hier voorliggende advies over hoe er vorm moet worden gegeven aan een dynamischer groeistrategie voor de komende jaren. Dit drieluik van adviesrapporten vormt een geheel en er zijn aanwijzingen dat het geheel van een dynamische groeistrategie niet werkt zonder ieder van die delen en omgekeerd: geen deel werkt optimaal zonder het geheel. Kortom: eerder dan een laissez faire-beleid is een actieve betrokkenheid van de overheid nodig voor meer 'ruimte' voor innovatie. Die actieve opstelling kan de overheid bewerkstelligen via de organisatie van opening in viervoud (zie par. 9.3 e.v.).

De uitbreiding van een macro-economische benadering met een micro-/mesobenadering met aandacht voor de institutionele aspecten en de daarop gerichte rol van de overheid is nog gaande. Op diverse terreinen van het innovatiesysteem is de kennis nog onvolledig, en zijn nader onderzoek en beleidsontwikkeling geboden om de lacunes te vullen.

\subsection{ANDERS DENKEN OVER INNOVATIEBELEID}

\section{Vijf overwegingen}

Mede op basis van een micro-/mesobenadering staan voor het nieuwe denken over innovatiebeleid volgens de raad vijf overwegingen centraal.

- Innovatie is meer dan wetenschap en technologie en omvat ook ondernemerschap, commercialisatie en marketing, organisatie binnen en tussen bedrijven, diffusie en kennisoverdracht.

- Innovatie is ontwikkeling van wat nog niet bestaat (exploratie) plus toepassing en verbetering van het bestaande (exploitatie) en de combinatie van de twee is een centrale uitdaging voor het innovatiebeleid op alle niveaus.

- De dynamiek van exploitatie en exploratie vergt opening naar nieuwe gebieden, samenwerking binnen en tussen bedrijven, verrassing en onvoorspelbaarheid, en naar uitdagers.

- Innovatie is voor een belangrijk deel fundamenteel onzeker, waardoor planning zeer beperkend kan zijn. Het gaat om de organisatie van het toeval en het faciliteren van creatieve destructie.

- Diversiteit is cruciaal, en innovatie vergt waardering, stimulering en mobilisatie van diverse, verspreide, lokale kennis, ideeën en opvattingen.

\section{Van industriebeleid naar innovatiebeleid}

In Nederland gaat het innovatiebeleid gaandeweg meer uit van het nieuwe denken, maar vertoont zij tevens sporen van het oude denken met zijn focus op R\&D. Het oude denken uit zich bijvoorbeeld ook in enkele aspecten van het 'sleutelgebiedenbeleid'. Het vertrekpunt voor dat beleid is de gedachte dat prioriteiten voor innovatie zijn toe te schrijven aan bepaalde bedrijfstakken of gebieden van technologie. Innovatie laat zich echter niet opsluiten in een bedrijfstak of techno- 
logie. Het heeft dan weinig zin meer om beleid te voeren in de gebruikelijke zin van beleid gericht op ontwikkeling of behoud van bedrijfstakken (industries) in Nederland. Het gaat eerder om onderdelen van waardeketens die over grenzen heen lopen. We moeten van een industriebeleid ${ }^{1}$ naar een innovatiebeleid. De uitvoeringspraktijk laat ook zien dat innovatie al snel buiten de oevers van sleutelgebieden treedt.

Afgezien van overheidssubsidiëring van bepaalde activiteiten met een innovatief karakter neigt het beleid er vervolgens toe de nadruk te leggen op vrijemarktwerking, liberalisatie en opheffing op marktbelemmeringen. In de vorige paragraaf is al betoogd dat het opheffen van marktverstoringen en obstakels vanuit het oogpunt van innovatie te simpel is. Markten zijn goed voor selectie en efficiëntie, maar zeker niet altijd voor creatie, innovatie en diversiteit.

\section{Meer dan wetenschap en technologie}

Er is een neiging, in Nederland en elders, om de focus te blijven richten op wetenschaps- en technologiebeleid. Naast die eenzijdige nadruk werkt dit ook een vorm van denken in de hand waarin zekerheid, beheersbaarheid en bestuurbaarheid vooropstaan. Wetenschap en technologie blijven van groot belang, maar de productie en benutting ervan (valorisatie) vergt evenzeer de aandacht. Technologische topinstituten hebben een prominente plaats in het huidige beleid. Die kunnen een functie hebben, maar wat telt is de context waarbinnen deze opereren. $\mathrm{Zij}$ dienen ingebed te zijn in een systeem van uitvinding, toepassing, ondernemerschap, commercialisatie, met organisatie van de bijbehorende samenwerking.

Het innovatiebeleid moet zich niet alleen richten op het functioneren van het innovatiesysteem, maar ook op wat genoemd wordt sociale innovatie. Daarbij gaat het over het veranderen van organisatie, management en arbeid zodanig dat nieuwe kennis breder wordt ontwikkeld en sneller wordt herkend, verspreid en aangewend voor nieuwe producten en diensten. Daarbij komt steeds nadrukkelijker het besef naar voren dat zonder het sociale het technologische niet kan renderen en ook slecht tot ontwikkeling komt. De opening voor verrassing en vernieuwing die vooral nodig is voor exploratie vergt in organisaties een zekere ruimte voor reflectie en experiment (slack), welke onder de druk van de roep om efficiëntie voortdurend weg gerationaliseerd dreigt te worden.

Op het belang van aandacht voor organisatorische aspecten van innovatie is eerder gewezen door het Innovatieplatform (2004). Organisatie is vooral van belang vanwege de wisselwerking die georganiseerd moet worden, binnen en tussen organisaties, tussen ontwikkelaars, dragers en toepassers van ideeën, om te komen tot waardevolle nieuwe combinaties. Die wisselwerking is onvoldoende.

\section{Diversiteit}

Innovatie komt voort uit een diversiteit van ideeën die lokaal zijn ingebed. Mensen ontwikkelen hun waarneming, kennis en oordeel in interactie met hun 
omgeving, langs hun levenspaden. Dat betekent dat zij daarin verschillen ('cognitieve afstand') en dat zij elkaar nodig hebben en elkaar aan kunnen vullen voor hun doen maar ook voor hun denken. In het huidige tijdsgewricht doen ondernemers en ook werknemers er goed aan hun vermogen tot samenwerking met andersdenkenden te ontwikkelen.

Veel hangt af van de overheid, hoewel ook zij niet in staat is alle mogelijkheden te overzien en te doorzien en er derhalve verstandig aan doet open oog te houden voor het bottom-up-proces van innovatie. Daarbij kan de overheid wel coördineren, zodat de inspanningen van afzonderlijke actoren gezamenlijk leiden tot een meerwaarde bij het dynamiseren van de economie. Bij coördineren moet men denken aan het bijeenbrengen van de verschillende soorten kennis bij gebruikers, werknemers en ontwikkelaars van kennis. De feitelijke invulling van het huidige beleid is ook in toenemende mate bottom-up, maar er blijven obstakels en daarmee aandachts- en actiepunten voor de overheid voor de realisatie van innovatief potentieel die een verdere opening vergen, in de vier vormen die in het voorgaande zijn uiteengezet.

\section{Exploratie en exploitatie}

Exploitatie (verbeteren van het bestaande) en exploratie (ontwikkelen wat nog niet bestaat) zijn beide nodig voor innovatie en dienen daarom beide te gebeuren, maar ze stellen verschillende eisen aan doel, middelen, mentaliteit, tijd en organisatie. Bestaande product- en kapitaalmarkten zijn geschikt voor exploitatie maar kunnen exploratie in de weg zitten. De overheid draagt in belangrijke mate verantwoordelijkheid voor de selectieomgeving, met name marktwerking, maar ook voor oplossingen van het falen ervan.

\section{Onzekerheid}

Innovatie is onzeker omdat zij mogelijkheden creëert die er nog niet zijn. Dat betekent onvoorspelbaarheid en een mogelijkheid van falen, in de zin dat er niet uitkomt wat men had gehoopt of verwacht. Een evolutionair perspectief kan helpen: het geeft aan dat nieuwe vormen kunnen ontstaan zonder doelgericht ontwerp vooraf, maar kan bijdragen aan de omgang met onzekerheid en vooral ook het benutten ervan. Het zoeken naar opening in het aflopen van de innovatiecyclus kan eveneens een bijdrage zijn. Innovatiebeleid is dan het stimuleren en handhaven van bronnen van diversiteit, de selectieomgeving (vooral markten) en de transmissie van succes. Maar het blijft een gegeven dat overleving niet goed voorspeld kan worden en mislukkingen erbij horen.

\section{Opening in vier richtingen}

Het toeval van innovatie kan volgens de innovatiecyclus tot op zekere hoogte worden georganiseerd. Exploratie wordt bevorderd door het onderwerpen van het bestaande aan nieuwe uitdagingen, die worden gezocht of die ons overkomen en die leiden tot nieuw inzicht in noodzaak en mogelijkheden voor nieuwe combinaties. Dat vergt opening in viervoud. Opening naar nieuwe gebieden, naar verschil van inzicht en appreciatie van de waarde ervan en inzet en het vermogen 
voor samenwerking om die waarde te realiseren; opening voor verrassing, risico en onzekerheid, en opening voor uitdagers. De plaats van deze verschillende vormen van opening voor de overgangen tussen exploitatie en exploratie, in een voortgaande cyclus van innovatie, zoals eerder in dit rapport besproken, wordt geillustreerd in figuur 9.1. Bij al die opening is een aandachtspunt hoe de overheid de instituties vorm kan geven en vernieuwen om die openingen tot stand te brengen. Dat wordt in volgende paragrafen toegelicht.

\section{Figuur 9.1 Vormen van opening in de cyclus van innovatie}

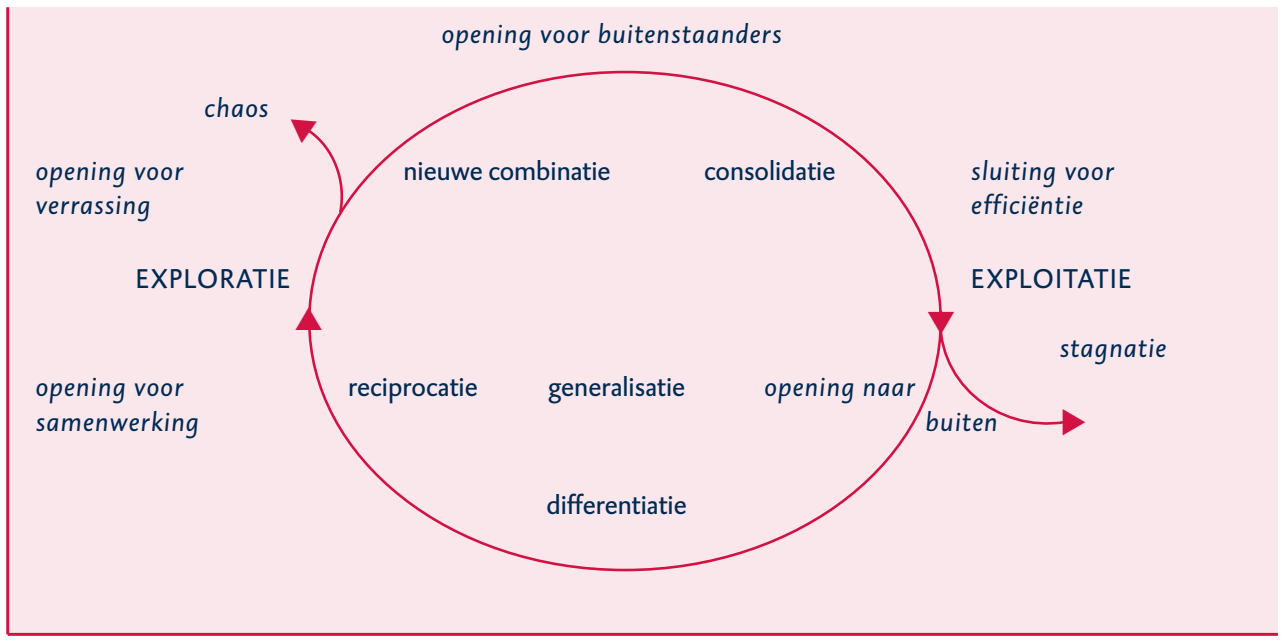

Wanneer exploratie een uitvinding genereert, wordt die onderworpen aan selectie op technische en commerciële levensvatbaarheid om tot een innovatie te komen. Om te overleven moet de innovatie ook passen in bestaande instituties en marktstructuren waarbij aandacht van de overheid vereist is om opening te bieden voor uitdagers die daar niet doorheen komen. Daarbij heeft de overheid een taak in het faciliteren van nieuwe markten. De oriëntatie van de overheid op de bijdrage aan creatie van nieuwe markten betekent meer dan het opheffen van obstakels voor marktwerking, met alleen oog voor efficiëntie. Het betekent vooral oog hebben voor het gegeven dat bestaande markten - en belangen - creatie wel eens in de weg kunnen zitten.

Nadat een innovatie is doorgebroken en zich verspreidt treedt sluiting op in de zin dat markten en andere instituties zich voegen naar de optimalisatie ervan. Concurrentie zorgt voor efficiënte allocatie en barrières daartoe dienen te worden voorkomen. Naarmate de markt verzadigd raakt, is er een prikkel om de prijsconcurrentie te verminderen door differentiatie van producten en om nieuwe toepassingen te zoeken. Om niet te stranden in stagnatie vergt dit openingen: naar buiten, voor toepassing en ontwikkeling in nieuwe omgevingen met nieuwe uitdagingen en bronnen van inspiratie, in andere bedrijven of in zelfstandig ondernemerschap, andere bedrijfstakken, andere regio's, andere markten, en andere landen (generalisatie). Die openingen komen hierna aan de orde. 
Dergelijke openingen, veranderingen van context, kunnen 'buiten' worden gezocht, maar kunnen ons ook van buitenaf overkomen. Daar ontmoet men nieuwe uitdagingen die nopen tot aanpassing, in de vorm van differentiatie, in eerste instantie vanuit bestaande repertoires en waar dat niet lukt in nieuwe combinaties met lokale praktijken (reciprocatie). Dat vergt opening voor samenwerking met andersdenkenden, waarbij men er verstandig aan doet te zoeken naar partners op optimale cognitieve afstand. Dit leidt vaak tot 'hybrides', die als voorlopers de transitie naar radicale vernieuwing inluiden. Zij bieden de basis voor verkenning van nieuwe combinaties, maar lopen op tegen inconsistenties en inefficiënties, waardoor prikkels en inzicht ontstaan voor een andere architectuur of basislogica, in een nieuwe configuratie van oude en nieuwe elementen. Dat levert onvoorzienbare nieuwe vormen op. Dit vergt opening voor de verrassing van een meer radicale innovatie.

Innovatie vergt dat men afstand neemt van gevestigde ideeën en praktijken, in nieuwe omgevingen met nieuwe uitdagingen en bronnen van inspiratie, langs een pad dat van exploratie naar exploitatie en van exploitatie weer naar exploratie leidt. Dit vergt opening naar buiten, naar nieuwe omgevingen of gebieden, zoals het buitenland, nieuwe bedrijfstakken en technologiegebieden, en nieuwe omgevingen voor werk en ondernemen, nieuwe partners en de bereidheid verassingen te accepteren.

\subsection{OPENING NAAR BUITEN}

\section{Buiten de grenzen van Nederland en van sectoren}

Innovatie is te onvoorspelbaar, divers, fluïde en fijnmazig om zich op te laten sluiten in bestaande bedrijfstakken en technologiegebieden. Waardeketens versplinteren en onderdelen ervan verspreiden zich over de wereld. Nieuwe combinaties overschrijden de grenzen van regio's en landen. In een nationaal innovatiebeleid ligt het voor de hand (overheids)steun te verlenen aan binnenlandse organisaties of individuen en niet aan buitenlandse. Steun aan buitenlanders valt al snel buiten de nationale competentie. Waardeketens en innovatieve activiteiten zijn echter in hoge mate grensoverschrijdend. Een beperking van de steun aan binnenlandse deelnemers kan het averechtse effect hebben dat de innovatie landelijk wordt ingekapseld, terwijl juist de opening naar buiten nodig is. Dit proces kan leiden tot verkeerde partners. Wetenschappers en bedrijven hebben contacten over de grens, maar als die contacten niet mee mogen doen aan subsidies ontstaat een prikkel om terwille van de subsidie goede buitenlandse contacten te verruilen voor mogelijk kwalitatief mindere contacten in het binnenland. In het beleid wordt hier al meer en meer rekening mee gehouden. In de feitelijke uitvoering van het sleutelgebiedenbeleid wordt internationale samenwerking gaandeweg meer meegenomen. Dat lijkt echter veelal een aanpassing ad hoc en achteraf te zijn.

De raad bepleit om, op basis van reciprociteit, de opening naar het buitenland mee te nemen vanaf het begin, in de doelstelling en inrichting van een programma of project, met buitenlandse projecten en contacten als integraal 
onderdeel. Als in programma's voor steun of subsidie opening naar het buitenland niet kan, omdat het in de Eu buiten de competentie van nationaal beleid ligt, dan moet men zich richten op samenwerking ter zake, in de EU. Daar liggen bijvoorbeeld mogelijkheden in het 'Kaderprogramma' voor samenwerking in onderzoek en ontwikkeling. Landelijk beleid zou gericht kunnen zijn op de opstap naar dergelijke grensoverschrijdende samenwerking. Dat vergt dat men zich niet bij voorbaat beperkt tot bepaalde bedrijfstakken of technologieën, en zelfs de opening naar nieuwe combinaties daartussen expliciet doel maakt van programma's.

Het huidige beleid opteert al enigszins voor opening naar buiten als het gaat om geselecteerde bedrijfstakken of gebieden. In de feitelijke uitvoering van het sleutelgebiedenbeleid zien we een voortgaande verruiming buiten de grenzen van het aanvankelijk aangewezen gebied, naar aanpalende projecten en kansen (zo leidt 'water' tot aandacht voor waterzuivering, dijkenbouw en baggerschepen, die in verschillende bedrijfstakken zitten en technologisch weinig met elkaar te maken hebben). Dat is naar het oordeel van de raad uitstekend. Het is echter van belang de legitimiteit van een dergelijke verbreding van aandacht ook aan te geven, omdat men anders wordt beschuldigd ten onrechte af te wijken van vooraf gekozen gebieden.

Een eerste aanbeveling is om openingen te maken voor verbindingen met relevante buitenlandse organisaties en individuen en voor activiteiten buiten bestaande bedrijfstakken en technologieën.

\section{Buiten de grenzen van bestaande kennis en bestaande disciplines}

Voor opening naar buiten, naar nieuwe gebieden en combinaties van bestaande gebieden is meer interdisciplinair onderzoek nodig, gelet op het bekende principe dat innovatie veelal plaatsvindt over de grenzen van verschillende gebieden heen. Interventie is nodig omdat er, in sommige wetenschapsgebieden meer dan in andere, sterke institutionele blokkades zijn. Deze doen zich voor in disciplinaire herkenbaarheid, beschikbaarheid van en toegang tot tijdschriften, en beoordeling door commissies, met sterke effecten op de vorming van reputaties en carrières. Een toenemend obstakel ligt in de tendens tot versmalling van het disciplinaire bereik van de tijdschriften waarin men moet publiceren om 'punten' te verwerven voor financiering en voor posities. Geleidelijk ontstaan wel meer interdisciplinair gerichte tijdschriften, maar het duurt lang voordat die in citatenindices zijn doorgedrongen en daar status verworven hebben.

Aanbevolen wordt om interdisciplinair onderzoek gerichter en intensiever te stimuleren.

Hierbij kan men onder andere denken aan speciale programma's bij Nwo en/of KNAW, en maatregelen waarmee interdisciplinair onderzoek op universiteiten wordt erkend en beloond in het kader van beoordelingssystemen en promotieprogramma's. 


\subsection{OPENING NAAR SAMENWERKING}

\section{Organisatie van vertrouwen}

In nieuwe omgevingen komt men nieuwe uitdagingen en mogelijkheden tegen. Om die kansen te benutten is samenwerking nodig. Dat vergt een passende mentaliteit en organisatie. Voor overheidorganisaties geldt dit mutatis mutandis eveneens. Ook daar doen zich mogelijkheden voor, in samenwerking met bedrijven en burgers. Het betreft hier samenwerking binnen organisaties en tussen organisaties, in allianties en netwerken. 'Open innovatie', in de zin van innovatie door samenwerking is als concept in de mode en wordt her en der met de mond beleden. Maar in feite blijven de aanhangers van dat concept denken in termen van eenzijdig voordeel in plaats van wederzijds voordeel; in termen van hiërarchie en de rol van opdrachtgever die zeggenschap heeft over een uitvoerder, in plaats van wederzijdse inbreng; en in termen van fusies en overnames in plaats van allianties. Ook de WRR heeft in een eerder rapport (WRR 2004) erop gewezen dat deze vorm van denken en vormgeving gebaseerd op boven- en onderschikking vooral aanleiding geeft tot wantrouwen en bijna onneembare barrières opwerpt om vertrouwen te organiseren.

Bedrijven en andere organisaties moeten de uitdaging aanvaarden om capaciteiten te ontwikkelen die nodig zijn voor het opbouwen van goede samenwerking en netwerken. Zodoende kweken zij een groter vermogen om op basis van vertrouwen te werken. Overigens zijn daar grenzen aan, wat onontbeerlijk is in de moderne, op netwerken gebaseerde kenniseconomie. Dat vergt ook een herwaardering van verschillen in de samenleving. Voorts biedt bemiddeling in samenwerking kansen voor zakelijk dienstverleners. Tot op zekere hoogte wordt die rol al gespeeld door bijvoorbeeld accountants, advocaten, banken, ingenieursbureaus, regionale ontwikkelingsmaatschappijen, de Syntensorganisatie, en andere dienstverleners. Dat gebeurt echter fragmentarisch, niet in de benodigde samenhang en afweging en niet met de benodigde specifieke knowhow en ervaring in samenwerking. De kunde van samenwerking ontwikkelt zich tot een vak. De overheid zou de ontwikkeling van zo'n vorm van zakelijke dienstverlening kunnen bevorderen, eerder dan zelf als tussenpersoon het mijnenveld van de begeleiding van samenwerking te betreden. ${ }^{2}$ Het vak van samenwerking zou ook gedoceerd kunnen worden aan wo- en hbo-instellingen.

Samenwerking is moeilijk en gaat vaak fout. Maatregelen gericht op het bevorderen van samenwerking ten behoeve van innovatie zullen succesvoller zijn wanneer de valkuilen van samenwerking van meet af aan in acht worden genomen. Bij samenwerking voor innovatie is extra vertrouwen nodig, omdat de beheersing door middel van contracten en materiële prikkels problematisch is. Als gevolg van de onzekerheid die gepaard gaat met innovatie en nieuwe kennis en competentie zijn de mogelijkheden tot contractueel vastleggen, waarnemen en evalueren van competenties en prestaties ('monitoring') beperkt. Beheersing door middel van contract en hiërarchie vergt normering, standaards, toezicht en administratie, die hoge transactiekosten kunnen geven en de beroepsuitoefening, 
creativiteit, intrinsieke motivatie en innovatie in de weg kunnen zitten. Exploratie vergt een zekere ruimte voor experiment en voor afwijking van vastgestelde normen of standaards. Bezien zou kunnen worden in hoeverre de overheid kan bijdragen aan de verdere ontwikkeling en verspreiding van kennis over de creatie van governance-mechanismen voor het creëren van vertrouwen (relational governance) en het formaliseren daarvan (formal governance) tussen ondernemingen en organisaties om verschillen met betrekking tot de organisatie, managementstijl en organisatiestructuur te overbruggen.

\section{Optimale flexibiliteit}

Samenwerking vergt vaak investeringen in wederzijds begrip en vertrouwen, die alleen verricht worden als er perspectief is voor voldoende duur van de relatie om die investering de moeite waard te maken. Daartoe moet gestreefd worden naar optimale in plaats van maximale flexibiliteit van relaties. Relaties moeten voldoende continuïteit bieden om investeringen in onderling begrip en vertrouwen rendabel te maken, maar niet zo lang dat zij leiden tot rigiditeit en te weinig cognitieve afstand.

\section{Mededinging en innovatie}

Hiervoor is al gewezen op het gegeven dat marktwerking op voorhand niet zaligmakend voor creatie en innovatie is. De overheid moet oog hebben voor ruimte, of liever het gebrek aan ruimte voor nieuwe markten. Al geruime tijd is er aandacht voor de noodzaak om het mededingingsbeleid meer af te stemmen op het innovatiebeleid, met name om voldoende ruimte te laten voor samenwerking ten behoeve van innovatie. Een accent dat wij daaraan toe willen voegen is het belang van samenwerking die lang genoeg duurt om investeringen uit te lokken die nodig zijn om de cognitieve afstand optimaal te benutten, zelfs als dit betekent dat er tijdelijk sprake is van exclusiviteit en daarmee de concurrentie dus beperkt wordt.

\section{Sociale innovatie}

Ook binnen organisaties geldt de logica dat een bepaalde continuïteit van werkrelaties vereist is om specifieke investeringen in wederzijds begrip en vertrouwen uit te lokken die vooral voor innovatie nodig zijn. Ook hier dient het doel optimale, niet maximale flexibiliteit te zijn.

Een uitdaging van fundamenteel belang, voor bedrijven en andere organisaties, is het organiseren van de combinatie van exploitatie en exploratie, binnen de organisatie of in samenwerking met anderen. Er is groeiend inzicht in problemen en mogelijkheden daartoe, zoals eerder in dit rapport is besproken. We gaven daar onder andere het voorbeeld van het Centraal Boekhuis, en het voorbeeld van de relatie tussen exploratie in kleine biotechnologiebedrijven en exploitatie in grote farmaceutische bedrijven.

Aanbevolen wordt om op alle niveaus meer aandacht te geven aan sociale innovatie, met name ter wille van het benutten van cognitieve afstand en de combinatie van exploitatie en exploratie. 
Onlangs hebben onderzoekers, vakbonden, werkgeversorganisaties en beleidsmakers hiertoe het Nederlands Centrum voor Sociale Innovatie opgericht, dat zich richt op het verbeteren van de organisatorische voorwaarden voor innovatie. Dit is een goed initiatief, waarbij naar verwachting de aandacht vooral zal uitgaan naar verbeteringen ten behoeve van exploitatie, in de vorm van verbeteringen in het kader van 'operationele excellentie'. Tegelijkertijd zijn er ook initiatieven nodig om exploratie te bevorderen, die verder van de dagelijkse bedrijfspraktijk af staat en daarom het risico lopen buiten beschouwing te blijven. Het gaat niet alleen om continue maar ook om discontinue verbetering.

Voorts wijst onderzoek zoals besproken in dit rapport en de achterliggende verkenning uit dat organisatorische condities voor creatieve teams sterk verwant zijn aan factoren, die ook de kwaliteit van arbeid bevorderen. Hier ligt volgens de raad een niet te versmaden kans voor een nieuwe coalitie tussen werkgevers en werknemers om tegelijk innovatie en kwaliteit van arbeid te bevorderen. Het bijeenbrengen van de verschillende soorten (innovatieve) kennis bij gebruikers, werknemers en ontwikkelaars van kennis is essentieel. Vakbonden en werkgeversorganisaties kunnen daarin een belangrijke rol spelen, evenals de institutionele infrastructuur voor scholing, arbeidsmarkt, sociaal beleid en arbeidsvoorwaardenvorming. Daarnaast kan de overheid ruimte scheppen voor experimenten en flexibiliteit van het bedrijfsleven enerzijds en voor ontplooiing van talenten en inkomens- en werkzekerheid anderzijds. Bij die ruimte voor experimenten kan de aandacht ook gericht worden op het wegnemen van belemmeringen voor arbeidsparticipatie van diverse groepen en voldoende zekerheid voor alle betrokkenen in de vorm van bijvoorbeeld levensloopregelingen. Op centraal niveau kunnen de overlegpartners de voorwaarden voor ruimte scheppen die nodig is in arbeidsorganisaties. Zo kan in cao-overleg als aandachtspunt de innovatie en productiviteitsverhoging permanent aan de orde komen. Het lijkt in dit licht een gemiste kans dat er geen deskundigen uit de het veld van arbeid en organisatie betrokken zijn bij het Innovatieplatform.

\section{Ook bij de overheid}

Voor zowel bedrijfsleven als overheid zijn er nog grotendeels onbenutte kansen voor samenwerking, met toeleveranciers en klanten of burgers, in de uitvoering, kwaliteitsverbetering en innovatie van goederen en vooral diensten, in zogenaamde platformorganisaties en open source-gemeenschappen. Wat de overheid betreft kunnen die een belangrijke bijdrage leveren aan 'horizontalisering' van publieke diensten (WRR 2006a).

Een aanbeveling is om in de organisatie van overheidsdiensten gebruik te maken van nieuwe vormen van organisatie, zoals platformorganisaties en open sourcegemeenschappen.

Naast ervaringen in Nederland kunnen voorbeelden van toepassing in centrale overheidsdiensten ook gevonden worden in het Verenigd Koninkrijk. Eerder gaven we het voorbeeld van het 'DirectGov'-project aldaar. Bij overheidsdiensten 
is hiervoor meer ruimte nodig voor initiatieven vanuit de frontoffice bij het initiëren van innovatie. Dat roept vragen op over de benodigde en mogelijke herziening van hiërarchische verhoudingen en van procedures van politieke en publieke verantwoording om die ruimte te bieden.

\section{Samenwerking voor valorisatie}

Opening naar samenwerking is ook nodig in de relatie tussen universiteit en bedrijfsleven. Voor innovatie zijn toepassing en diffusie van bestaande kennis belangrijker dan de productie van nieuwe kennis. Dat vergt aandacht voor kennisoverdracht in onderwijs en kennisoverdracht naar bedrijven (valorisatie). De raad benadrukt het primaire belang van goed onderwijs voor de diffusie van innovaties. Voorts is niet alleen voor de overdracht, maar ook voor de productie van kennis een intensievere wisselwerking tussen universiteit en bedrijfsleven van belang. Dit vooral in het licht van de in macro-economisch onderzoek geconstateerde Nederlandse paradox (goed in kennis en octrooien maar niet in nieuwe producten). In de analyse van dit rapport hebben wij aangegeven dat het enerzijds gaat om toepassing van kennis vanuit de universiteit in het bedrijfsleven en anderzijds om inspiratie voor onderzoek in universiteiten vanuit ervaring met toepassing in het bedrijfsleven en elders. Hier steekt weer het vraagstuk van de wisselwerking tussen exploitatie en exploratie de kop op. Tegelijk constateerden wij dat marktwerking binnen de universiteit, in de zin van druk van commercialisatie van wetenschappelijk onderzoek en concurrentie daarin de bronnen voor exploratie kan vernietigen, zoals eerder gebeurd is bij bedrijven. De vraag is hoe de wisselwerking kan worden bevorderd met behoud van bescherming van de bronnen van exploratie. Daarvoor kwamen we tot het idee van third spaces tussen universiteit en bedrijfsleven.

Aanbevolen wordt dat de overheid zorgt dat marktwerking binnen universiteiten niet zo ver gaat dat de basis voor exploratie wordt afgebroken. Valorisatie (exploitatie) dient niettemin bevorderd te worden, maar het gaat dan niet alleen om toepassing van wetenschappelijke kennis, maar ook om de inspiratie daartoe (in exploratie) vanuit ervaringen in de praktijk. Om deze doelen van bescherming van exploratie, toepassing en inspiratie tegelijk te bereiken beveelt de raad het gebruik aan van 'third spaces', in virtuele of actuele zin.

Zoals uiteengezet in dit rapport fungeren third spaces als een omgeving voor exploratie. Zij zorgen voor ontmoeting en samenwerking tussen in toepassing geïnteresseerde wetenschappers, die dat zien als een vorm van toetsing en een bron van inspiratie, en onderzoekers of ontwikkelaars uit het bedrijfsleven die zich vanuit hun ervaringen in exploitatie, maar op enige afstand van hun praktijk, willen wijden aan exploratie. De third space kan ook dienen als een platform voor de later nog te bespreken spin-offs, vanuit universiteit, bedrijfsleven of combinaties van de twee, in teams die zich in de third space kunnen formeren. De cognitieve afstand tussen de twee groepen kan productief zijn, mits men de condities en capaciteiten ontwikkelt voor het overbruggen ervan. Een conditie is dat dergelijke activiteit aan beide kanten als legitiem en belangrijk gezien wordt. Bij het 
bedrijfsleven moet het gezien worden als een stap in een carrière, niet als een onderbreking ervan. Bij de universiteit vergt het erkenning van de activiteit in de meting van prestaties en het gewicht ervan in de allocatie van middelen en carrières. Hier ligt een taak voor de overheid. Het moet ook mogelijk zijn voor universiteiten om niet voor elk kort advies of contact meteen een contract te moeten eisen ('uurtje factuurtje'). Dat is de transactiekosten niet waard en belemmert de kennismaking en beoordeling van de optimaliteit van cognitieve afstand die aan vruchtbare samenwerking voorafgaat. Daar moet men de tijd voor krijgen.

Een voorbeeld van een virtuele third space is het Netherlands Genomics Inititiative, dat projecten opzet en begeleidt tussen universitair en privaat onderzoek. Een voorbeeld van een actuele, fysieke third space is de High Tech Campus in Eindhoven, waar Philips bij betrokken is. Een voorbeeld van een spin-off daaruit is het eerder besproken geval van Liquavista (box 6.2). De betrokken actoren (in het bedrijfsleven en in de academische wereld) hebben vormen van interactie ontwikkeld die veelal gericht zijn op zowel toepassing als inspiratie van wetenschappelijk onderzoek. De omvang en urgentie van het vraagstuk van valorisatie lijkt door deze activiteiten inmiddels geringer dan in recente beleidsdiscussies is verondersteld. Dat de effecten kennelijk nog niet goed zijn doorgestroomd in meer innovatie is begrijpelijk: dat kost tijd. Er is echter ook ruimte voor verbetering en ontwikkeling van de mogelijkheden en vormen, en uitwisseling van ervaring.

\section{Samenwerking tussen beroepsonderwijs en bedrijfsleven}

Terwijl een minderheid van kennisintensieve kleine bedrijven de absorptiecapaciteit heeft voor samenwerking met universiteiten, geldt voor de grote meerderheid van het mkb dat aansluiting bij het hbo een meer realistische optie is. De raad steunt dan ook het initiatief van de regering om het hbo middelen te geven voor toegepast onderzoek, vooral ten behoeve van het $\mathrm{mkb}$. De raad ondersteunt ook het RAAK-programma, dat wordt gesubsidieerd door het ministerie van OCW en wordt uitgevoerd door de Stichting Innovatie Alliantie, voor samenwerking tussen hbo en groepjes kleine bedrijven. Ook de eerder ingestelde 'innovatievouchers' voor het mkb sluiten beter aan bij hbo-instellingen dan bij universiteiten en het instrument is ook in die richting bijgesteld.

\section{Netwerken en regionaal beleid}

In samenwerking spelen netwerken een belangrijke rol. Het gaat hier om effecten van het aantal potentiële deelnemers aan netwerken, de dichtheid van het netwerk, de aanwezigheid van centrale spelers, de sterkte van verbindingen, inen uitstroom van deelnemers en verbindingen naar netwerken elders. Groeiend inzicht in dergelijke effecten biedt mogelijkheden voor verdieping van beleid dat zich richt op het verbeteren van samenwerking voor innovatie. Het aldus configureren van patronen van samenwerking is eerder een kwestie voor regionale dan voor centrale overheden. 
Regionaal innovatiebeleid speelt om twee redenen een rol. Ten eerste zijn bedrijven in regionaal ingebedde netwerken minder gemakkelijk verplaatsbaar naar andere regio's in concurrerende landen. Ten tweede is het vanuit ons perspectief van het benutten van bronnen van lokale diversiteit van kennis en ervaring van belang om vooral van beneden af innovatieve initiatieven te stimuleren en, letterlijk en figuurlijk, de ruimte te geven. Het is in specifieke regionale contexten dat samenwerking gestalte krijgt. Daarin spelen netwerken een belangrijke rol.

Gezien de lokale specificiteit en historische wortels van kennis, omstandigheden, successen en mislukkingen, zijn claims voor universele modellen voor regionale ontwikkeling zelden geldig. Niet alleen R\&D biedt perspectief voor regio's. Naast wetenschap en technologie zijn ook testing/prototyping, commercialisatie, productie, toelevering en distributie van belang en iedere regio heeft zijn eigen competenties en potentieel op uiteenlopende gebieden. Deze overwegingen, aangevuld met de noodzaak om op het juiste moment dat beleid te kiezen en te implementeren dat aansluit bij de verschillende ontwikkelingsstadia van regionale clusters, leiden de raad tot de volgende aanbeveling.

Aanbevolen wordt om in regionaal innovatiebeleid te streven naar terughoudendheid in ontwerp en sturing door de centrale overheid en voldoende ruimte te laten voor regionale initiatieven en specificiteiten.

De centrale overheid dient te waken tegen het gebruik van universele sjablonen voor regionale ontwikkeling, en van vooropgezette soorten activiteit en gebieden van onderzoek en ontwikkeling Dat wil niet zeggen dat de centrale overheid hier geen rol heeft. Zij heeft een taak in afstemming met andere regio's in binnen- en buitenland. Er is een gevaar dat innovatie in de regio opgesloten wordt en ook daar is enige centrale sturing ten aanzien van opening naar buiten nodig. Er is bovendien een gevaar van lokaal cliëntisme en uitsluiting en hierbij is voor de landelijke overheid een toezichthoudende taak weggelegd.

Verder moet er ruimte komen voor beleidsmogelijkheden op het niveau van lagere overheden om door creatie van regionale netwerken, met name tussen het $\mathrm{mkb}$, gemeenten, provincies, mbo- en hbo-opleidingen om aan sociale innovatie te werken. Ook is er een mogelijke rol van wo en hbo voor wisselwerking met het bedrijfsleven en om verbindingen te leggen buiten de regio. De plaatselijke overheid kan hier verder faciliteren door voorzieningen te treffen voor het bijeenbrengen van ervaringen, succesverhalen en het organiseren van terugkoppeling waarmee lokale en regionale actoren kennis kunnen opdoen van ontwikkelingen en aanpakken elders.

Ten slotte kunnen third spaces een rol spelen in regionaal innovatiebeleid, voor exploratie, maar ook als platform voor verbindingen naar buiten, naar andere regio's in binnen- en buitenland, om te voorkomen dat innovatie regionaal opgesloten raakt. Die behoefte aan internationale verbindingen sluit aan op de inter- 
nationale oriëntatie en contacten van universiteiten die bij third spaces betrokken zijn.

In de invulling van het sleutelgebiedenbeleid wordt gaandeweg meer rekening gehouden met regionale en lokale specificiteiten. Dat is een goede zaak, maar daardoor nadert het sleutelgebiedenbeleid de 'Pieken in de Delta'. Het is dan efficiënt om de twee beleidsinstrumenten te integreren, zonder de initiële nationale, sectorale en regionale beperkingen die in sleutelgebieden besloten liggen.

\section{$9 \cdot 5$ OPENING VOOR VERRASSINGEN}

Creativiteit en innovatie, die leiden tot experimentele nieuwe combinaties van eigenschappen van producten of functies en nieuwe configuraties van belanghebbenden, passen vaak niet in vooropgezette doelen, bestaande markstructuren en belangen, en instituties (zoals wettelijke regelingen, normen, standaards, gewoonten, denkwijzen, en ambtelijke procedures en taakverdelingen). Die staan voor zekerheid, beheersbaarheid en bestuurbaarheid. Dat kan bijdragen aan efficiëntie, maar kan ook de ontwikkeling van innovaties tegenhouden, verrassing blokkeren en het kan leiden tot prohibitief hoge transactiekosten.

Een obstakel is ook gelegen in het feit dat er bij sommige meer complexe innovaties verschillende partijen betrokken zijn met verschillende belangen, die soms leiden tot patstellingen die partijen zelf niet kunnen doorbreken. In de voorgaande hoofdstukken en in de achter dit rapport liggende verkenning worden daarvan tal van voorbeelden gegeven. Een tweede obstakel is gelegen in transactiekosten verbonden aan complexe processen van afstemming met en tussen verschillende overheden, overigens veelal om goede redenen van verantwoording van de besteding van publieke middelen.

Eerder wezen we erop dat de opzet van het sleutelgebiedenbeleid in eerste instantie verassingen buiten gevestigde partijen en sectoren uitsloot. Gelukkig is gaandeweg in de feitelijke uitvoering van het sleutelgebiedenbeleid een voortgaande verruiming buiten de grenzen van het aanvankelijk aangewezen gebied ontstaan naar aanpalende projecten en kansen.

Aanbevolen wordt om de aandacht voor het opheffen van obstakels voor nieuwe combinaties te intensiveren, om daarmee de gewenste opening voor verrassingen te bereiken.

Hieronder worden enkele gedachten ontwikkeld over een mogelijke invulling.

\section{Verantwoording op basis van uitkomsten}

In programma's en projecten voor innovatie vergt opening voor verrassing verantwoording op basis van beoordelingscriteria die niet vooraf de inhoud bepalen. Men kan denken aan verantwoording achteraf van het proces, inclusief veranderingen van richting daarin, en/of verantwoording op basis van uitkomsten die 
niet vooraf de inhoud vastleggen, zoals behaalde octrooien, licenties, publicaties, citaten, nieuwe producten of processen en beoordelingen door peer groups en gebruikers (inclusief erkenning van legitiem en leerzaam falen).

\section{Doorbreken van patstellingen}

Voor de opening voor innovatieprojecten die vastlopen in systeemfalen in de vorm van onoplosbare patstellingen tussen belanghebbenden kan men denken aan een 'deblokkadebrigade', die waar mogelijk helpt om patstellingen te doorbreken. Hoe dat zou moeten of kunnen hangt af van het geval. Afhankelijk van het geval vergt het een of meer van de volgende attributen: deskundigheid in de kunst van samenwerking, een positie in het overheidsapparaat die voldoende gezag en invloed biedt om problemen op te lossen waarbij verschillende publieke en private partijen betrokken zijn, de positie om als afnemer op te treden, en/of de autoriteit om doelen, taken of randvoorwaarden op te leggen. Omdat systeemfalen veelal betrekking zal hebben op de beleidsterreinen van verschillende ministeries en beleidsterreinen van centrale zowel als regionale of lokale overheden, zal het team veelal interdepartementaal moeten zijn. Om te komen tot opbouw van competentie en acceptatie voor deze activiteit zal gedacht moeten worden aan een interdepartementaal orgaan of dito afdeling waar dit gebeurt. Dat moet echter de flexibiliteit om maatwerk te leveren, met teams die specifiek op het geval zijn toegesneden, niet in de weg zitten.

Eerder gaven we het voorbeeld van het Elektronisch Patiënten Dossier (EPD). In Engeland wordt het top-down opgelegd, en dat geeft ook problemen. Het is een lastig geval en daarom interessant als voorbeeld. In het geval van het EPD heeft juist de overheid een taak, omdat het grotendeels een publieke sector betreft (zorg), politieke afwegingen een rol spelen en de patiënt als degene die er vooral baat bij heeft nauwelijks of geen invloed uit kan oefenen. Het geval illustreert ook dat deblokkage niet alleen de vorm aan hoeft te nemen van een overheid die zich mengt in het proces van afstemming en overleg. Misschien ligt de oplossing in het opleggen van een verplichting voor registratie waardoor partijen gedwongen worden om het eens te worden.

\section{Verlaging van transactiekosten}

Transactiekosten voor bedrijven worden voor een belangrijk deel door de overheid in de opzet en uitvoering van programma's zelf gecreëerd, vanwege afstemming, toestemming en verantwoording binnen en tussen horizontale en verticale geledingen binnen en tussen betrokken departementen. Eerder noemden we ervaringen met het sleutelgebied 'Flowers en food'. De vraag is of per saldo de baten van een programma de transactiekosten waard zijn. Ook als dat wel het geval is, is het een plicht van de overheid om de door haar gecreëerde kosten zelf te dragen. Dat zou ook een prikkel kunnen geven om die kosten te verlagen. Op dit probleem van institutionele belemmeringen werd eerder gewezen door het Innovatieplatform (2004), dat ook signaleerde dat bij de overheid een duidelijk aanspreekpunt ontbreekt. Zoals eerder is besproken, kan gedacht worden aan het inzetten van 'accountmanagers' die een enkel contactpunt bieden voor externe 
betrokkenen en de taak hebben om intern, binnen de overheid, de benodigde coördinatie te verzorgen en te komen tot eenduidige besluiten en eisen. Dit kan de kennis en ervaring leveren die nodig zijn om de transactiekosten te verlagen door de nodige stroomlijning van procedures en competenties.

\subsection{OPENING VOOR UITDAGERS}

Een obstakel voor innovatie is gelegen in de bestaande structuren van markten en instituties die de toegang voor vooral kleinere innovatieve ondernemingen moeilijk maken. Om te waarborgen dat opening is veiliggesteld dient er alle ruimte te zijn voor uitdagers. De veelal kleine innovatieve outsiders hebben niet de tijd, de ervaring, de contacten, de absorptiecapaciteit en het retorisch vermogen om deel te nemen aan de vormgeving en uitvoering van een innovatieprogramma. Gemiddeld genomen is het $\mathrm{mkb}$ het laatste decennium eerder minder dan meer innovatief is geworden. Het percentage innovatieve mkb-bedrijven ligt volgens de meeste indicatoren ver onder het EU-gemiddelde. In de feitelijke uitvoering van het sleutelgebiedenbeleid ontstaat gaandeweg meer opening voor kleine bedrijven. Dat is voor verdere verbetering vatbaar. Men zal daarbij echter oplopen tegen schaaleffecten in transactiekosten, ook in cognitieve zin, die aandacht vragen. De vraag is ook in hoeverre deze initiatieven aansluiten op andere maatregelen en instellingen ten behoeve van het betrekken van kleine bedrijven bij innovatie, zoals loketten voor kennisoverdracht van onderwijsinstellingen, Syntens en de innovatievouchers. Bovendien moet het potentieel van kleine bedrijven niet alleen betrokken worden in de uitvoering, achteraf, maar ook in keuze en ontwerp van programma's.

Voor ondernemerschap is er al veel behartenswaardig beleid, onder andere voor financiering (garantiekredieten bij banken, 'technopartner', 'uitdagerskrediet'), kennisoverdracht (Syntens, RAAK, innovatievouchers), inzet tot verbetering van EU-octrooien (minder kosten, grotere snelheid), vereenvoudiging van regelgeving en vermindering van administratieve lasten. Niettemin is het veelal voor innovatieve ondernemers moeilijk om bestaande markten binnen te komen of nieuwe markten te creëren. De overheid kan een belangrijke rol spelen door op te treden als leading customer. Dat betreft vooral gebieden waar de overheid verantwoordelijkheid draagt voor publieke belangen waarbij zonder optreden van de overheid innovatie onvoldoende totstandkomt, in gebieden zoals natuur en milieu, energie en duurzaamheid, gezondheid, veiligheid en water. Dan kan de overheid gedwongen zijn om te doen aan picking winners, en te accepteren dat veel uitbestede innovatie niet de gehoopte uitkomst zal geven.

Aanbevolen wordt om op gebieden van publiek belang de overheid meer op zoek te laten gaan naar innovaties en meer dan nu een afnemer te laten zijn van innovaties, waarbij nadrukkelijk kleine innovatieve bedrijven in staat worden gesteld om hun ideeën en producten te ontwikkelen. 
Hoe kan deze aanbeveling in de praktijk vorm krijgen? De overheid kan een belangrijke rol spelen in het verlagen van de onzekerheid met betrekking tot de vraag en zodoende meer kansen voor ondernemerschap creëren. Een belangrijke doelstelling hierbij moet zijn dat in de praktijk niet alleen gevestigde grote bedrijven de overheid bereiken, maar dat juist ook uitdagers, nieuwe en kleine bedrijven, hier aan deelnemen. De in hoofdstuk 5 besproken SBIR-regeling in de vs levert hierin een belangrijke bijdrage en lijkt in Nederland navolging te vinden. Een bijkomend voordeel hierbij is het demonstratie-effect: een geslaagde innovatie voor de overheid geldt als demonstratie en signaal voor verdere ontwikkeling van de markt voor het bedrijf.

Voor de opening voor uitdagers kan verder worden gedacht aan instanties die ondernemers helpen hun weg te vinden door institutionele belemmeringen en die obstakels identificeren en signaleren om dergelijke belemmeringen te verminderen. Daarvoor bestaat een interdepartementaal netwerk met de naam 'Koplopersloket', gevestigd in het ministerie van Economische Zaken. Eerder gaven wij enkele illustraties van wat het loket voor ondernemers gedaan en betekend heeft. Bij het ministerie van Financiën is een vergelijkbare 'Innovation Room' ingesteld ter stimulering en begeleiding van nieuwe vormen van financiële dienstverlening. Het is de bedoeling dat per geval iedere relevante overheidsorganisatie wordt vertegenwoordigd door een afgevaardigde die op zijn beurt een netwerk heeft opgezet in zijn eigen organisatie. Dit komt in de buurt van het eerder aangegeven concept van 'account management'. De samenstelling van het team hangt af van de aard van de vraag. Wanneer een idee in aanmerking komt voor behandeling wordt een apart team van experts geformeerd, en de Innovation Room zal binnen enkele weken reageren nadat de details van het idee zijn ontvangen (bron: website ministerie van Financiën). Aangezien dit beleid reeds bestaat is een aanbeveling niet nodig, maar de raad moedigt de regering aan dergelijke activiteiten te steunen en waar nodig te versterken.

\section{Spin-offs}

Een potentiële bron van innovatie ligt in het reservoir aan ideeën die in grote bedrijven zijn ontwikkeld, maar daar niet tot ontwikkeling en toepassing komen, omdat ze niet passen in perceptie, strategie of portfolio van het grote bedrijf. Het komt dan voor dat degene die het idee ontwikkelde het bedrijf verlaat om het in een eigen onderneming verder te ontwikkelen: insiders worden dan outsiders. Vanuit het gezichtspunt van het vraagstuk van exploitatie en exploratie is het voordeel dat het idee voortkomt (exploratie) uit de praktijk en ervaring van het bedrijf (exploitatie). De spin-off creëert ruimte voor ontwikkeling, buiten de gevestigde orde van het bedrijf en onderwerpt het idee aan nieuwe eisen en mogelijkheden die de innovatie kunnen stimuleren. Dit is een voorbeeld van opening naar nieuwe contexten voor toepassing en ontwikkeling van ideeën. Het kan in het belang van de grote bedrijven zelf zijn om dergelijke spin-offs te bevorderen en sommige bedrijven doen dit ook (Philips, DSM). Bijvoorbeeld door een terugkomgarantie voor het geval de innovatie mislukt (wat zeer waarschijnlijk is), en de werknemer gelouterd terugkomt om weer gemotiveerd binnen het 
bedrijf aan de slag te gaan. Het zijn vaak niet de slechtste werknemers die een dergelijk pad willen proberen. Het bedrijf zou de stap ook kunnen faciliteren met durfkapitaal, zelf of door het inschakelen van een externe durfkapitalist. Eerder werd het voorbeeld gegeven van 'Liquavista' als spin-off van Philips. Als de innovatie lukt en blijkt te passen in de portfolio van het bedrijf, kan de ondernemer uitgenodigd worden de innovatie intern verder te ontwikkelen naar toepassing (exploitatie), met gebruik van de meer uitgebreide middelen en expertise van het grote bedrijf. Als de innovatie niet past verkoopt men zijn aandeel. De waarde voor het grote bedrijf kan liggen in extra rendement, in het zich presenteren als een werkgever die ruimte voor innovatie biedt, in het verkennen van wat zich buiten de waarneming en competentie van het bedrijf afspeelt, als een bron voor exploratie en het profiteren van de complementaire competenties van grote en kleine bedrijven.

Een volgende aanbeveling is om grote bedrijven en hun werknemers te stimuleren tot respectievelijk het faciliteren en het initiëren van spin-offs.

Voor een mogelijke invulling kan men wellicht denken aan de verlaging van eventuele drempels, zoals concurrentiebedingen. Wellicht liggen er ook mogelijkheden in de vertaling naar overheids- en cao-regelingen, bijvoorbeeld in de sfeer van fiscus en pensioenen. De overheid zou ook kunnen werken aan bewustwording en de verspreiding van best practices op het gebied van corporate venturing.

\section{Uitdagers in academisch onderzoek}

Wat betreft de opening voor verrassing en diversiteit heeft de raad een aanbeveling inzake de verdeling van middelen voor universiteiten via de eerste en tweede geldstroom. Er is een neiging om financiering van onderzoek te verschuiven van de eerste naar de tweede geldstroom. Daar zijn argumenten voor, maar ook tegenargumenten. Hoewel de competitie om onderzoeksgeld tussen onderzoekers nog wel groter is in de tweede dan in de eerste geldstroom, neemt ook de competitie om gelden binnen universitaire onderzoeksscholen toe, onder druk van externe beoordelingen en concurrentie om goede onderzoekers. In de eerste geldstroom is er grotere diversiteit van beoordeling, wat van belang is in disciplines waar er geen duidelijke consensus is over kwaliteit en er sprake is van rivaliserende scholen van denken. In de eerste geldstroom is er meer begeleiding van en toezicht op het onderzoeksproces. Op basis van rijkere en meer 'taciete' kennis ligt daar een betere basis voor een efficiënte, effectieve en snelle besturing en beoordeling van processen. De beoordeling van succes als voorwaarde voor beloning kan geschieden op basis van een mix van de bekende maatstaven van octrooien, publicaties, citaten, peer review, en enquêtes bij bedrijven en andere gebruikers en belanghebbenden.

Voor thematisch onderzoek in de tweede geldstroom wordt vaak niet alleen een globale thematiek aangegeven, maar wordt ook een inhoudelijke uitwerking van onderzoeksthema's gegeven. Dat gaat te ver, en voor de invulling moet meer opening worden geboden voor inzichten en ervaringen uit het diverse veld van 
onderzoekers. Programmatische sturing is ook kwetsbaar voor modieuze opvattingen. De raad is wel voorstander van persoonsgerichte subsidies voor succesvolle onderzoekers, uit de tweede geldstroom (Spinoza, Veni/Vidi/Vici). Daar ligt ook een typische overheidstaak: succesvol onderzoek creëert anders dan commercieel succesvolle innovaties immers niet zijn eigen fondsen om op het succes voort te bouwen.

Voor opening voor verrassing en benutting van bronnen van diversiteit wordt aanbevolen om voor de subsidie van door onderzoekers ingediende onderzoeksvoorstellen niet verder middelen over te hevelen van de eerste naar de tweede geldstroom.

Ook kan worden overwogen om, al of niet als onderdeel van de eerste geldstroom, universiteiten financiële ruimte te geven voor de voorfinanciering van samenwerkingsprojecten met andere universiteiten en/of bedrijven, die bij succes beloond worden met additionele financiering. Een dergelijk voorstel werd ook gedaan door het Innovatieplatform (2004). Dit is in lijn met ons algemene uitgangspunt dat zo veel mogelijk ruimte gegeven moet worden aan initiatieven vanuit de diversiteit van lokale kennis, eerder dan aan centrale programmering. Dergelijke, zo mogelijk additionele financiering zou onder andere gebruikt kunnen worden voor opzet en voorfinanciering van de eerdergenoemde third spaces tussen universiteit en bedrijfsleven.

\subsection{PUBLIEKE MIDDELEN}

In de voorafgaande paragrafen van dit hoofdstuk is een aantal bouwstenen aangereikt voor een micro/meso geïnspireerd beleid, waarmee de ontwikkeling van exploratie en exploitatie ter hand kan worden genomen door de daarvoor benodigde vormen van opening te creëren. Dit heeft raakvlakken met de inzet van publieke middelen voor het innovatiebeleid.

De overheid heeft meerdere verantwoordelijkheden die in dit verband aandacht behoeven. Ten eerste is er de algemene verantwoordelijkheid voor de voorspoedige ontwikkeling van de economie van ons land. Innovatie is hiervoor cruciaal en het innovatiebeleid is derhalve van veel betekenis. Waar innovatie vooral een aangelegenheid is van de private sector en het beleid zich vooral bedient van instrumenten in de sfeer van initiëren, bevorderen en faciliteren wordt dit beleid niet primair bepaald door een budgettaire invalshoek.

Daarnaast heeft de overheid de zorg voor de voortbrenging van collectieve voorzieningen, waarvan de definitie grofweg luidt dat alleen de overheid hierin kan voorzien dan wel dat zonder overheidsvoorziening het aanbod van deze goederen suboptimaal is. Veel van deze collectieve goederen hebben een grote maatschappelijke betekenis, zoals het milieu, energie, gezondheid, water, en mobiliteit. Door innovaties kunnen deze voorzieningen belangrijk worden verbeterd. Waar het bedrijfsleven niet het voortouw neemt zal de overheid het moeten doen. 
De raad is van mening dat de overheid de schaarse publieke middelen vooral op dit terrein van grote maatschappelijke behoeften zou moeten inzetten. De mogelijkheden tot innovatie op deze terreinen zijn groot en hetzelfde geldt voor de noodzaak om op deze terreinen innovatief te opereren. Hier kan worden gedacht aan financiering van thematisch onderzoek, het financieren van vertaling van kennis naar prototypen en het testen daarvan, bijdragen aan de eerdergenoemde third spaces tussen universiteit en bedrijfsleven, de eerdergenoemde uitbesteding van onderzoek en ontwikkeling aan nieuwe kleine, innovatieve bedrijven, inzet van het koplopersloket om kleine innovatieve bedrijven te helpen hun weg te vinden en obstakels te omzeilen, subsidies voor gebruik door consumenten die innovaties de markt intrekken, ${ }^{3}$ en het inzetten van een 'deblokkadebrigade' indien bestaande initiatieven vastlopen in patstellingen tussen stakeholders.

Natuurlijk zijn ook private partijen als aanbesteder of uitvoerder op dit terrein actief. Voor zover publieke middelen ten behoeve van innovatie ten goede komen aan private partijen, zou het criterium van additionaliteit van toepassing moeten zijn. De vraag die hierbij moet worden gesteld is in hoeverre zonder interventie of steun van de overheid de activiteit niet verricht zou worden. Het feit dat een activiteit succesvol is, is niet voldoende reden voor subsidie, zoals in het huidige beleid van backing winners. Het moet ook nodig zijn omdat anders het bestaande potentieel niet benut wordt.

Ten derde zal bij de toekenning van publieke middelen bezien moeten worden of voldaan is aan de wezenskenmerken van innovatie zoals fundamentele onzekerheid. Dat vergt dat men bij steun in exploratie incalculeert dat vele projecten zullen 'mislukken', maar dat dit bij innovatie behoort.

\subsection{TOT SLOT}

We hebben vele aanbevelingen gegeven om de bepleite opening in viervoud te bevorderen, om daarmee de cyclus van innovatie draaiende te houden. We moeten ons echter ook realiseren dat dit in belangrijke mate een kwestie van mentaliteit en cultuur is, waar de overheid slechts op langere termijn invloed op uit kan oefenen. De raad constateert met zorg dat het met die culturele instelling in sommige opzichten de verkeerde kant opgaat. Dit betekent dat we ons meer moeten inzetten voor de traditionele opening voor diversiteit en verschil, de waardering daarvoor en pragmatisch gebruik ervan. Opening naar het buitenland is een noodzakelijke voorwaarde voor het innovatieve vermogen van Nederland. Opening voor samenwerking in het bedrijfsleven moet niet alleen met de mond beleden worden, maar ook in de praktijk worden gebracht. Dit betekent meer dan $\mathrm{nu}$ het geval is behoud van zelfstandigheid en het bewaren van cognitieve afstand in allianties, in plaats van een voortgaand streven naar integratie middels fusies en overnames. In innovatie gaat het er meestal om dat beide partijen elkaars opdrachtgevers en uitvoerders zijn. Dat vergt een verandering van attitude. Het vergt ook een wijs omgaan met de mogelijkheden en beperkingen van vertrouwen en dat is een kunst die men moet leren. 
Ten slotte willen we een beleidsvisie in overweging geven van Nederland als hub of buzz: dé plek voor waardevolle wetenschappelijke, economische en artistieke creativiteit. Een plaats waar uitdagers van de gevestigde orde zich ontwikkelen. De verschillende vormen van opening, en de aanbevelingen om die te realiseren, convergeren op dit concept. De in dit rapport genoemde achterstanden in innovatie vergroten de urgentie om te investeren in talent en om barrières voor creativiteit en innovatie weg te nemen. Daarbij pleiten we voor het in ere herstellen van traditionele Nederlandse waarden als tolerantie en ontdekkingslust. ${ }^{4}$ Nederland als een plaats waar mensen elkaar op een optimale cognitieve afstand kunnen ontmoeten en waar waarde wordt gecreëerd door nieuwe producten te ontwikkelen en door productie, distributie en consumptie op nieuwe manieren te organiseren (zie ook WRR 2003). Dit ligt in het verlengde van de traditionele functie van Nederland als knooppunt van goederenstromen, als knooppunt van stromen van mensen met hun kennis en hun behoefte aan kennis. Dit vergt ook experimenten met nieuwe vormen van organisatie om waarde te creëren in nieuwe internationale omstandigheden. Wellicht kunnen de Nederlanders opnieuw en zelfs op een breder terrein dan in het verleden de rol van intermediair vervullen en anderen helpen hun cognitieve afstand te overbruggen. Dat vergt dat wij ons vermogen tot samenwerking met andersdenkenden verder ontwikkelen, zodat we grote cognitieve afstanden kunnen overbruggen, en nieuwe waarde kunnen creëren. 


\section{NOTEN}

1 Industriebeleid duidt hier op een op bedrijfstakken (industries) gericht beleid, niet op een beleid dat ruimte geeft aan de industrie in de Nederlandse betekenis van nijverheid. Het eerste is ongewenst, het tweede niet.

2 Onverlet de latere aanbeveling voor het instellen van een 'deblokkadebrigade' voor wanneer interventie door de overheid onmisbaar is.

3 Zoals de onlangs opnieuw ingestelde regeling voor gebruik van zonnecellen.

$4 \quad$ Nederlands toppositie in de creative class ranking (Florida 2005), en Amsterdam in het bijzonder (Stam et al. 20o8), is hier een goede basis voor. 


\section{LITERATUUR}

Acs, Z.J. and D.B. Audretsch (2003) 'Innovation and Technological Change', in Z.J. Acs and D.B. Audretsch (eds.) Handbook of entrepreneurship research, Kluwer: Boston.

Anderson, N.R. and R.M. Gasteiger (2008) 'Innovation and Creativity in Organizations: Individual and Work Team Research Findings and Implications for Government Policy,' in B. Nooteboom and E. Stam (eds.) Micro foundations for innovation policy, Amsterdam: Amsterdam University Press, 2008.

Ark, B. van en G. de Jong (2004) Productiviteit in dienstverlening. Assen: Van Gorcum. AWT (2003) Backing winners. Den Haag: AWT.

Bartlett, C.A. and S. Goshal (1989) Managing across borders - Transnational solution, Boston MA: Harvard Business School Press.

Bathelt, H., A. Malmberg and P. Maskell (2004) 'Clusters and knowledge. Local buzz, global pipelines and the process of knowledge creation', Progress in Human Geography, 28, 31-56.

Bleeke, J. and D. Ernst (1991) 'The way to win in cross-border alliances', Harvard Business Review, November/December, 127-135.

Boschma, R.A. (2005) 'Rethinking regional innovation policy. The making and breaking of regional history', blz. 249-271 in G. Fuchs and P. Shapira (eds.) Rethinking regional innovation and change. Path dependency or regional breakthrough?, Dordrecht: Springer Verlag.

Boschma, R.A. and J.G. Lambooy (1999) 'Evolutionary Economics and Economic Geography', Journal of Evolutionary Economics, 9: 411-429.

Bosma, N. and V. Schutjens (2008) 'Mapping entrepreneurial activity and entrepreneurial attitudes in European regions', International Journal of Entrepreneurship and Small Business (forthcoming).

Bruland, K. and D.C. Mowery (2005) 'Innovation through time', blz. 349-379 in J. Fagerberg, D.C. Mowery en R.R. Nelson (eds.) The Oxford Handbook of Innovation, Oxford: Oxford University Press.

Burt, R. (1992) 'Structural holes: the social structure of competition', blz. 57-91 in N. Nohria and R. Eccles (eds.) Networks and organizations: structure, form and action. Boston: Harvard Business School Press.

Cantwell, J.A. and L. Piscitello (1999), 'The emergence of corporate international networks for the accumulation of dispersed technological capabilities', Management International Review, Special Issue 1, 123-147.

Centraal Bureau voor de Statistiek (2007) Het Nederlandse ondernemingsklimaat in cijfers, Den Haag: CBS.

Centraal Plan Bureau (2007) De effectiviteit van de innovatievoucher 2004 en 2005, Den Haag: CPB.

Chesbrough, H. (2006) Open innovation - The new imperative for creating and profiting from technology, Boston: Harvard Business School Press.

Coleman, J.S. (1988) 'Social capital in the creation of human capital', American Journal of Sociology 94: 95-120.

Competentiecentrum Transities (2006) Quick scan Koplopersloket, Utrecht: CT. 
Crescenzi, R., A. Rodriguez-Pose and M. Storper (2007) 'The territorial dynamics of innovation: a Europe-United States comparative analysis', Journal of Economic Geography 7: 673-709.

Dicken, P. (2003) Global Shift: Reshaping the global economic map in the 21st Century, London: Sage.

Dussen, J. van der (2006) ‘Gehaktdag exit?’, Overheidsmanagement 9: 221-223.

EIM (2006) Internationale Benchmark Ondernemerschap 2005, Zoetermeer: EIM Business and Policy Research.

Erken, H. and M. Ruiter (2005) Determinanten van de private $R \& D$-uitgaven in international perspectief, Den Haag: Ministerie van Economische Zaken/Dialogic.

European Commission (2006) European Trend Chart on Innovation. Annual Innovation Policy Trends and Appraisal Report-The Netherlands, 2006, Brussels: European Commission Enterprise Directorate-General.

Fagerberg, J. (2005) 'Innovation: Guide to the literature', blz. 1-26 in J. Fagerberg, D.C. Mowery and R.R. Nelson (eds.) The Oxford handbook of innovation, Oxford: Oxford University Press.

Fallick, B., C.A. Fleischman and J.B. Rebitzer (2006) 'Job-hopping in Silicon Valley; Some evidence concerning the micro-foundations of a high-tech cluster', Review of Economics and Statistics 88: 472-481.

Frenken, K., F.G. van Oort and T. Verburg (2007) 'Related variety, unrelated variety and regional economic growth', Regional Studies 41 (5), 685-697.

Geest, L. van der and L. Heuts (2008), 'Barriers for Innovation', in B. Nooteboom and E. Stam (eds.), 2008 Micro-foundations for innovation policy, Amsterdam: Amsterdam University Press.

Gilsing, V.A. (2005) The dynamics of innovation and interfirm networks, exploration, exploitation and co-evolution. Cheltenham: Edward Elgar.

Gilsing, V.A. en B. Nooteboom (2006) 'Exploration and exploitation in biotechnology', Research Policy 35 (1): 1-23.

Gould, S.J. (1977) 'The return of hopeful monsters', Natural History 86 (June/July): 22-30.

Grabher, G. (1993) The embedded firm. On the socioeconomics of industrial networks, London: Routledge.

Granovetter, M.S. (1973) 'The strength of weak ties', American Journal of Sociology 78 (6): 1360-1381.

Hawkins, R.W. (2007) University research in an 'Innovation society', blz. 171-191 in OECD, Science, technology and innovation indicators in a changing world; Responding to policy needs, Paris: OECD.

Henderson, R.M. and K.B. Clark (1990) 'Architectural innovation: The reconstruction of existing product technologies and the failure of established firms', Administrative Science Quarterly 35: 9-30.

Hoffmann, A.N. and M. Junge (2006) Documenting Data on High-growth Firms and Entrepreneurs across 17 Countries, Mimeo, Fora Copenhagen.

InAxis (2004) Beschrijving en analyse database innovatie en kwaliteit publieke sector; Rode draden en witte plekken, Zoetermeer: EIM Consult.

Innovatieplatform (2004) Vitalisering van de kenniseconomie, Den Haag: Innovatieplatform. 
Innovatieplatform (2006) Kennisinvesteringsagenda, Den Haag: Innovatieplatform. Innovatieplatform (2007) Werkprogramma 2007, Den Haag: Innovatieplatform. Jaumotte, F. and N. Pain (2005) 'Innovation in the Business Sector', Economic Department Working Papers 459, Paris: OECD.

Jong, J. de en B.H.G. Jansen (2007) Innovatie in het MKB. Ontwikkelingen 1999-2007. Zoetermeer: EIM.

Lerner, J. (1999) 'The government as venture capitalist: The long-run effects of the SBIR program', Journal of Business 72 (3): 285-297.

Lester, R.K. and M.J. Piore (2004) Innovation - The missing dimension, London: Harvard University Press.

Li, Y., B. Nooteboom and W. Vanhaverbeke (2007) The effects of industrial and country difference in supplier relationships on the radicalness of innovations, Diepenbeek: Universiteit van Hasselt.

Marshall, A. (189o) Principles of Economics, London: Macmillan.

Martin, B.R. and P. Tang (2007) The benefits from publicly funded research, Science Policy Research Unit, University of Sussex.

McKinsey (2007) Versnellen arbeidsproductiviteitsgroei in Nederland, Amsterdam: McKinsey \& Company.

Meeus, M.T.H. en J. Faber (2006) 'Interorganizational Relations and Innovation: A Review and a Theoretical Extension', blz. 67-87 in J. Hage and M.T.H. Meeus (eds.), Innovation, science and institutional change. A Research Handbook, New York: Oxford University Press.

Mokyr, J. (1990) The lever of riches: Technological creativity and economic progress, Oxford: Oxford University Press.

Nambisan, S. and M. Sawhney (2007) 'Meet the innovation capitalist', Harvard Business Review, March 24.

NAO, National Audit Office (2006) Achieving innovations in central government organizations, can be downloaded from www.governmentontheweb.org.

Nooteboom, B. (1992) 'Towards a dynamic theory of transactions', Journal of Evolutionary Economics 2: 281-299.

Nooteboom, B. (1993) 'Firm size effects on transaction costs', Small Business Economics 5: 283-295.

Nooteboom, B. (1999) Inter-firm alliances; Analysis and design, London: Routledge.

Nooteboom, B. (200o) Learning and innovation in organizations and economies, Oxford: Oxford University Press.

Nooteboom, B. (2001) 'From evolution to learning and language', blz. 41-69 in J. Foster and J.S. Metcalfe (eds.) Frontiers in evolutionary economics, Cheltenham: Edward Elgar.

Nooteboom, B. (2002) Trust: Forms, foundations, functions, failures and figures, Cheltenham: Edward Elgar.

Nooteboom, B., W.P.M. Vanhaverbeke, G.M. Duijsters, V.A. Gilsing and A. van den Oord (2007) 'Optimal cognitive distance and absorptive capacity', Research Policy 36 : 1016-1034.

Nooteboom, B. and R. Went (2008) 'Innovation and Organisation', in B. Nooteboom en E. Stam (eds.) Micro-foundations for innovation policy, Amsterdam: Amsterdam University Press 2008. 
Nooteboom, B. and E. Stam (eds.) (2008), Micro-foundations for innovation policy, WRR-Verkenning nr. 18, Amsterdam: Amsterdam University Press.

OECD (2005a) Innovation Policy and Performance, A Cross-Country Comparison, Paris: OECD.

OECD (2005b) Oslo Manual; Guidelines for collecting and interpreting innovation data, 3 rd edition, OECD/Eurostat.

OECD (2005c) OECD Economic Surveys, Netherlands 2006, 2, Paris: OECD.

OECD (2007) Science, technology and innovation indicators in a changing world; Responding to policy needs, Paris: OECD.

Ponds, R. en F.G. van Oort (2006) Kennishubs in Nederland. Ruimtelijke patronen van onderzoekssamenwerking, Rotterdam/Den Haag: NAi uitgevers/Ruimtelijk Planbureau.

Porter, M.E., K. Schwab and X. Sala-i-Martin (2007) The Global Competitiveness Report 2007-2008, London: Palgrave MacMillan.

Raspe, O., F.G. van Oort en P. de Bruijn (2004) Kennis op de kaart. Ruimtelijke patronen in de kenniseconomie, Rotterdam/Den Haag: NAi uitgevers/Ruimtelijk Planbureau.

Schenk, H. (2005) Mergers, efficient choice, and international competitiveness. Bandwagon behaviour and industrial policy implications, Cheltenham: Edward Elgar.

Schumpeter, J.A. (1934) The theory of economic development, Cambridge Mass: Harvard University Press.

Stam, E. (2008) 'Entrepreneurship and Innovation', in B. Nooteboom and E. Stam (eds.), Micro-foundations for innovation policy, Amsterdam: Amsterdam University Press, 2008.

Storper, M. and A.J. Venables (2004) 'Buzz: the Economic Force of the City', Journal of Economic Geography 4(4):351-370.

Tweede Kamer (2004) 'Evaluatie vBтB’, Brief van de Minister van Financiën, Kamerstukken II, vergaderjaar 2004-2005, 29 949, nr. 1.

Von Hippel, E. (2005) Democratizing innovation, Cambridge (Mass)/London: MIT.

Vries, G. de (2008) 'Innovation and Macroeconomics', in B. Nooteboom and E. Stam (eds) Micro-foundations for innovation policy, Amsterdam: Amsterdam University Press.

WRR (1980) Plaats en toekomst van de Nederlandse industrie, Den Haag: Wetenschappelijke Raad voor het Regeringsbeleid.

WRR (2003) Nederland Distributieland, Den Haag: Wetenschappelijke Raad voor het Regeringsbeleid.

WRR (2004) Bewijzen van goede dienstverlening, Amsterdam: Amsterdam University Press

WRR (2006a) Lerende overheid. Een pleidooi voor probleemgerichte politiek, Amsterdam: Amsterdam University Press.

WRR (2006b) De verzorgingsstaat herwogen. Over verzorgen, verzekeren, verheffen en verbinden, Amsterdam: Amsterdam University Press.

WRR (2007) Investeren in werkzekerheid, Amsterdam: Amsterdam University Press.

Wuyts, S., M. Colombo, S. Dutta and B. Nooteboom (2005) 'Empirical tests of optimal cognitive distance', Journal of Economic Behaviour and Organization, 58/2: 277302. 


\section{BIJLAGE}

\section{GESPREKSPARTNERS}

Openbaar bestuur, organisaties

Minister van Economische Zaken mevr. Maria van der Hoeven

Arthur Docters van Leeuwen (AFM)

Cees Schuyt (Raad van State)

Pieter Waasdorp (ministerie van EZ)

Hans de Groene (ministerie van EZ)

Henk Groeneveld (ministerie van EZ)

Nora van der Wenden (ministerie van Ez)

Stephan Raes (ministerie van EZ)

Bart v.d. Gevel (ministerie van Ez)

Jeroen Bartelse (ministerie van EZ)

Arjen Gielen (ministerie van Az)

Dirk Schoenmaker (ministerie van Fin)

Peter Wansink (ministerie van ocw)

Ton van der Wijst (SER)

Jan Peter van der Toren (Innovatieplatform)

Rens van Tiburg (AWT)

Paul Diederen (AWT)

Jacquie van Stigt (FNV Bondgenoten)

Anja Jongbloed (FNV Bondgenoten)

Fredy Peltzer (FNV Bondgenoten)

Hans van der Steen (vNo/NCW)

Frans v.d. Zee (TNO)

Fietje Vaas (TNO, NCSI)

\section{Bedrijfsleven}

Hans Wijers (Akzo Nobel)

Jan Maat (Unilever)

Jan van der Eijk (Shell)

Peter Wierenga (Philips)

Guy Kerpen (Philips)

Gert van Maanen (vm NMB Postbank)

Michiel Westerman (Motek BV)

Freerk Bisschop (Ecoventures)

Ron Kok (Отв)

Fred Gardner (Teamwork Technology)

Andries Meuzelaar (ondernemer)

Ger Vos (Innovatienetwerk agro)

\section{Wetenschap en onderwijs}

Amandus Lundqvist (TU/e)

Wim Vanhaverbeke (TU/e) 
Bart Verspagen (TU/e)

Vareska van der Vrande (TU/e)

Hans van Luijk (TUD)

Alfred Kleinknecht (TUD)

Rob Munnig Smid (TUD)

Luc Soete (UM)

Frank den Butter (vU)

Ewald Engelen (UvA)

Evert-Jan Visser (UU)

Niels Bosma (UU)

Henri Burgers (EUR)

Rudy Rabbinge (Wageningen Universiteit)

Sybolt Noorda (VSNU)

Jasper Tuytel (Hogeschool Rotterdam)

Lex de Lange (Groningen Zernike Group)

Cees Buisman (Wetsus Leeuwarden)

Mark de Jong (Telematica Instituut)

Diederik Zijderveld (NGI) 


\section{RAPPORTEN AAN DE REGERING}

\section{Eerste raadsperiode (1972-1977)}

1 Europese Unie

2 Structuur van de Nederlandse economie

3 Energiebeleid

Gebundeld in één publicatie (1974)

$4 \quad$ Milieubeleid (1974)

5 Bevolkingsgroei (1974)

6 De organisatie van het openbaar bestuur (1975)

7 Buitenlandse invloeden op Nederland: Internationale migratie (1976)

8 Buitenlandse invloeden op Nederland: Beschikbaarheid van wetenschappelijke en technische kennis (1976)

9 Commentaar op de Discussienota Sectorraden (1976)

10 Commentaar op de nota Contouren van een toekomstig onderwijsbestel (1976)

11 Overzicht externe adviesorganen van de centrale overheid (1976)

12 Externe adviesorganen van de centrale overheid (1976)

13 Maken wij er werk van? Verkenningen omtrent de verhouding tussen actieven en niet-actieven (1977)

14 Interne adviesorganen van de centrale overheid (1977)

15 De komende vijfentwintig jaar - Een toekomstverkenning voor Nederland (1977)

16 Over sociale ongelijkheid - Een beleidsgerichte probleemverkenning (1977)

Tweede raadsperiode (1978-1982)

17 Etnische minderheden (1979)

A. Rapport aan de Regering

B. Naar een algemeen etnisch minderhedenbeleid?

Plaats en toekomst van de Nederlandse industrie (1980)

Beleidsgerichte toekomstverkenning

Deel 1: Een poging tot uitlokking (1980)

Democratie en geweld. Probleemanalyse naar aanleiding van de gebeurtenissen in Amsterdam op 30 april 1980

Vernieuwingen in het arbeidsbestel (1981)

Herwaardering van welzijnsbeleid (1982)

Onder invloed van Duitsland. Een onderzoek naar gevoeligheid en kwetsbaarheid in de betrekkingen tussen

Nederland en de Bondsrepubliek (1982)

Samenhangend mediabeleid (1982)

\section{Derde raadsperiode (1983-1987)}

Beleidsgerichte toekomstverkenning

Deel 2: Een verruiming van perspectief (1983)

Waarborgen voor zekerheid. Een nieuw stelsel van sociale zekerheid in hoofdlijnen (1985)

Basisvorming in het onderwijs (1986)

De onvoltooide Europese integratie (1986)

Ruimte voor groei. Kansen en bedreigingen voor de Nederlandse economie in de komende tien jaar (1987)

Op maat van het midden- en kleinbedrijf (1987)

Deel 1: Rapport aan de Regering

Deel 2: Pre-adviezen

31 Cultuur zonder grenzen (1987) 
De financiering van de Europese Gemeenschap. Een interimrapport (1987)

Activerend arbeidsmarktbeleid (1987)

Overheid en toekomstonderzoek. Een inventarisatie (1988)

\section{Vierde raadsperiode (1988-1992)}

Rechtshandhaving (1988)

Allochtonenbeleid (1989)

Van de stad en de rand (1990)

Een werkend perspectief. Arbeidsparticipatie in de jaren '90 (1990)

Technologie en overheid (1990)

De onderwijsverzorging in de toekomst (1991)

Milieubeleid. Strategie, instrumenten en handhaafbaarheid (1992)

Grond voor keuzen. Vier perspectieven voor de landelijke gebieden in de Europese Gemeenschap (1992)

Ouderen voor ouderen. Demografische ontwikkelingen en beleid (1993)

\section{Vijfde raadsperiode (1993-1997)}

Duurzame risico's. Een blijvend gegeven (1994)

Belang en beleid. Naar een verantwoorde uitvoering van de werknemersverzekeringen (1994)

Besluiten over grote projecten (1994)

Hoger onderwijs in fasen (1995)

Stabiliteit en veiligheid in Europa. Het veranderende krachtenveld voor het buitenlands beleid (1995)

Orde in het binnenlands bestuur (1995)

Tweedeling in perspectief (1996)

Van verdelen naar verdienen. Afwegingen voor de sociale zekerheid in de 21e eeuw (1997)

Volksgezondheidszorg (1997)

Ruimtelijke-ontwikkelingspolitiek (1998)

Staat zonder land. Een verkenning van bestuurlijke gevolgen van informatie- en communicatietechnologie (1998)

\section{Zesde raadsperiode (1998-2002)}

Generatiebewust beleid (1999)

Doorgroei van arbeidsparticipatie (2000)

Ontwikkelingsbeleid en goed bestuur (2001)

Naar een Europabrede Unie (2001)

60 Nederland als immigratiesamenleving (2001)

61 Van oude en nieuwe kennis. De gevolgen van ICT voor het kennisbeleid (2002)

Duurzame ontwikkeling. Bestuurlijke voorwaarden voor een mobiliserend beleid (2002)

63 De toekomst van de nationale rechtsstaat (2002)

64 Beslissen over biotechnologie (2003)

65 Slagvaardigheid in de Europabrede Unie (2003)

66 Nederland handelsland. Het perspectief van de transactiekosten (2003)

67 Naar nieuwe wegen in het milieubeleid (2003) 


\section{Zevende raadsperiode (2003-2007)}

Waarden, normen en de last van het gedrag (2003)

De Europese Unie, Turkije en de islam (2004)

Focus op functies. Uitdagingen voor een toekomstbestendig mediabeleid (2005)

72 Vertrouwen in de buurt (2005)

Rapporten aan de Regering nrs. $1 \mathrm{t} / \mathrm{m} 67$ en publicaties in de reeks Voorstudies en achtergronden zijn niet meer leverbaar. Alle studies van de WRR zijn beschikbaar via de website www.wrr.nl.

Rapporten aan de Regering nrs. $68 \mathrm{t} / \mathrm{m} 79$ zijn verkrijgbaar in de boekhandel of via Amsterdam University Press, Herengracht 221, 1016 BC Amsterdam (www.aup.nl). 


\section{VERKENNINGEN}

\section{Zevende raadsperiode (2003-2007)}

1 J. Pelkmans, M. Sie Dhian Ho en B. Limonard (red.) (2003) Nederland en de Europese grondwet

$2 \quad$ P.T. de Beer en C.J.M. Schuyt (red.) (2004) Bijdragen aan waarden en normen

3 G. van den Brink (2004) Schets van een beschavingsoffensief. Over normen, normaliteit en normalisatie in Nederland

4 E.R. Engelen en M. Sie Dhian Ho (red.) (2004) De staat van de democratie. Democratie voorbij de staat

5 P.A. van der Duin, C.A. Hazeu, P. Rademaker en I.J. Schoonenboom (red.) (2004) Vijfentwintig jaar later. De Toekomstverkenning van de WRR uit 1977 als leerproces

6 H. Dijstelbloem, P.L. Meurs en E.K. Schrijvers (red.) (2004) Maatschappelijke dienstverlening. Een onderzoek naar vijf sectoren

7 W.B.H.J. van de Donk, D.W.J. Broeders en F.J.P. Hoefnagel (red.) (2005) Trends in het medialandschap. Vier verkenningen

8 G. Engbersen, E. Snel en A. Weltevrede (2005) Sociale herovering in Amsterdam en Rotterdam. Eén verhaal over twee wijken

9 D.J. Wolfson (2005) Transactie als bestuurlijke vernieuwing. Op zoek naar samenhang in beleid en uitvoering

10 Nasr Abu Zayd (2006) Reformation of Islamic Thought. A Critical Historical Analysis J.M. Otto (2006) Sharia en nationaal recht. Rechtssystemen in moslimlanden tusssen traditie, politiek en rechtsstaat P.L. Meurs, E.K. Schrijvers en G.H. de Vries (2006) Leren van de praktijk. Gebruik van lokale kennis en ervaring voor beleid W.B.H.J. van de Donk, A.P. Jonkers en G.J. Kronjee (red.) (2006) Geloven in het publieke domein. Verkenningen van een dubbele transformatie

D. Scheele, J.J.M. Theeuwes, G.J.M. de Vries (red.) (2007) Arbeidsflexibiliteit en ontslagrecht J.J.C. Voorhoeve (2007) From War to the Rule of Law. Peace Building after Violent Conflicts 


\section{WEBPUBLICATIES}

\section{Zevende raadsperiode (2003-2007)}

WP 1 Opvoeding, onderwijs en jeugdbeleid in het algemeen belang

WP 2 Ruimte voor goed bestuur: tussen prestatie, proces en principe

WP 3 Lessen uit corporate governance en maatschappelijk verantwoord ondernemen

WP 4 Regulering van het bestuur van maatschappelijke dienstverlening: eenheid in verscheidenheid

WP 5 Een schets van het Europese mediabeleid

WP 6 De regulering van media in internationaal perspectief

WP 7 Beleid inzake media, cultuur en kwaliteit: enkele overwegingen

WP 8 Geschiedenis van het Nederlands inhoudelijk mediabeleid

WP 9 Buurtinitiatieven en buurtbeleid in Nederland anno 2004: analyse van een veldonderzoek van 28 casussen

WP 10 Geestelijke gezondheid van adolescenten: een voorstudie

WP11 De transitie naar volwassenheid en de rol van het overheidsbeleid: een vergelijking van institutionele arrangementen in Nederland, Zweden, Groot-Brittanië en Spanje

WP 12 Klassieke sharia en vernieuwing

WP13 Sharia en nationaal recht in twaalf moslimlanden

WP 14 Climate strategy: Between ambition and realism

WP 15 The political economy of European integration in the polder: Asymmetrical supranational governance and the limits of legitimacy of Dutch EU policy-making

WP 16 Europe in law, law in Europe

WP 17 Faces of Europe: Searching for leadership in a new political style

WP 18 The psychology and economics of attitudes in the Netherlands

WP 19 Citizens and the legitimacy of the European Union

WP 20 No news is bad news! The role of the media and news framing in embedding Europe

WP 21 Actor paper subnational governments: Their role in bridging the gap between the EU and its citizens

WP 22 The Dutch third sector and the European Union: Connecting citizens to Brussels

WP 23 Europe in parliament: Towards targeted politicization

WP 24 Europe in the Netherlands: Political parties

WP 25 The EU Constitutional Treaty in the Netherlands: Could a better embedding have made a difference?

WP 26 How to solve the riddle of belated Euro contestation in the Netherlands?

WP 27 Connection, consumer, citizen: Liberalising the European Union gas market

WP 28 Dutch EU-policies with regard to legal migration - The directive on family reunification

WP 29 The accession of Turkey to the European Union: The political decision-making process on Turkey in The Netherlands

WP 30 The Habitats Directive: A case of contested Europeanization

WP 31 Encapsulating services in the 'polder': Processing the Bolkestein Directive in Dutch Politics

WP 33 De casus Inburgering en Nationaliteitswetgeving: iconen van nationale identiteit

WP 34 In debat over Nederland

WP 35 Veel voorkomende criminaliteit

WP 36 Gevaarlijke stoffen

WP 37 ICT en internet

WP 38 Voedsel en geneesmiddelen

WP 39 Waterbeheer en waterveiligheid 


\section{Innovatie vernieuwd}

Innovatie is meer dan kennis en goede ideeën. Innovatie is ook een kwestie van organisatie en vaardigheden. Een nieuw, open innovatiebeleid met aandacht voor sociale innovatie is nodig. In dit rapport geeft de Wetenschappelijke Raad voor het Regeringsbeleid (WRR) aanbevelingen voor verbetering van het innovatieproces in Nederland op micro- en mesoniveau: in bedrijven, tussen bedrijven en in netwerken. Het innovatiebeleid dat de WRR voorstelt, biedt openingen: over grenzen heen, voor samenwerking, voor verrassingen en voor uitdagers. Innovatie over grenzen heen van landen, sectoren, technologieën en regio's. Samenwerking en uitwisseling bevorderen in en tussen bedrijven en instellingen. Vormen van organisatie en toezicht die innovatie stimuleren, obstakels wegnemen en ruimte geven aan uitdagers.

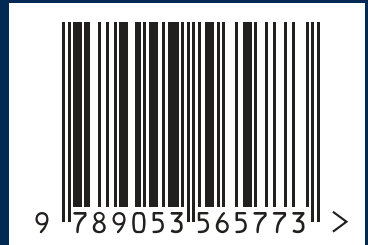

ISBN 978-90-5356-577-3 